Andrews University

Digital Commons @ Andrews University

2002

\title{
A Historically and Culturally Contextualized Proposal for Health Evangelism in Latvia
}

Anna Galeniece

Andrews University

Follow this and additional works at: https://digitalcommons.andrews.edu/dmin

Part of the Practical Theology Commons

\section{Recommended Citation}

Galeniece, Anna, "A Historically and Culturally Contextualized Proposal for Health Evangelism in Latvia" (2002). Professional Dissertations DMin. 574.

https://dx.doi.org/10.32597/dmin/574

https://digitalcommons.andrews.edu/dmin/574

This Project Report is brought to you for free and open access by the Graduate Research at Digital Commons @ Andrews University. It has been accepted for inclusion in Professional Dissertations DMin by an authorized administrator of Digital Commons @ Andrews University. For more information, please contact repository@andrews.edu. 


\section{ABSTRACT}

\section{A HISTORICALLY AND CULTURALLY CONTEXTUALIZED \\ PROPOSAL FOR HEALTH EVANGELISM IN LATVIA}

by

Anna Galeniece

Adviser: Jerry Moon 


\title{
ABSTRACT OF GRADUATE STUDENT RESEARCH
}

\author{
Dissertation
}

\author{
Andrews University \\ Seventh-day Adventist Theological Seminary
}

Title: A HISTORICALLY AND CULTURALLY CONTEXTUALIZED

PROPOSAL FOR HEALTH EVANGELISM IN LATVIA

Name of the researcher: Anna Galeniece

Name and degree of faculty adviser: Jerry Moon, Ph.D.

Date completed: May 2002

Problem

Seventh-day Adventist church leaders in Latvia have used several approaches and methods for reaching people with the gospel, but proclamation evangelism has served as the main program. However, this method has lost its effectiveness since the middle-1990s. Therefore, today the necessity of discovering and developing new ways and strategies has become crucial. One approach to reach the Latvian population could be health evangelism, which has achieved immense success in many parts of the world since the beginning of the Adventist health message in the 1860 s. 


\section{Method}

The research utilized pertinent materials from books, periodicals, and the Internet. The purpose was to design a health evangelism program for Latvia. The research began by investigating Latvian society and culture, in order to better understand the needs of the population. Next it traced the history and assessed the current situation of Adventist evangelism and church growth in Latvia. After establishing a biblical foundation for health evangelism, and surveying the historical background of Adventist health evangelism in North America and Europe, the study proposed a strategy for health evangelism in Latvia.

\section{Results}

The proposal for health evangelism in Latvia includes three main aspects: (1) churches as training centers providing a variety of health-related seminars and cooking schools; (2) churches' outreach into the communities with health-food restaurants and health education during public evangelistic campaigns; and (3) establishing medical institutions such as a dental or medical clinic, a care home for the elderly, and self-supporting health ministries. Finally, the study presents guidelines for implementing and evaluating the program.

\section{Conclusions}

Contemporary Latvian society presents great challenges and opportunities for Seventh-day Adventist evangelism. The preparation of the church for health evangelism and its implementation will enable Latvian Adventists to better serve the people of the communities and thus attract them to become acquainted with Jesus Christ as their Healer and Savior. 


\author{
Andrews University \\ Seventh-day Adventist Theological Seminary
}

\title{
A HISTORICALLY AND CULTURALLY CONTEXTUALIZED \\ PROPOSAL FOR HEALTH EVANGELISM IN LATVIA
}

\author{
A Dissertation \\ Presented in Partial Fulfillment \\ of the Requirements for the Degree \\ Doctor of Ministry
}

by

Anna Galeniece

May 2002 



\section{A HISTORICALLY AND CULTURALLY CONTEXTUALIZED \\ PROPOSAL FOR HEALTH EVANGELISM IN LATVIA}

A dissertation

presented in partial fulfillment

of the requirements for the degree

Doctor of Ministry

by

Anna Galeniece

APPROVAL BY THE COMMITTEE:

Geny moon

Faculty Adviser,

Jerry Moon

Associate Professor of Church History

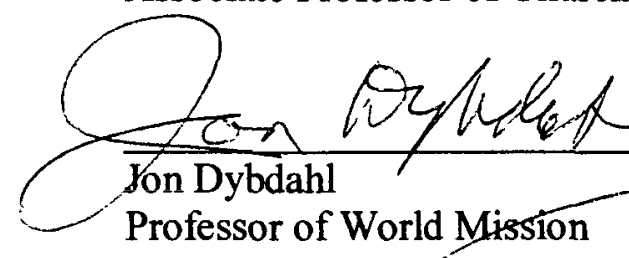

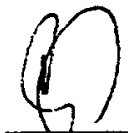

Jiri Moskala

\section{Leos 8}

Asfociate Professor of Old Testament

Exegesis and Theology

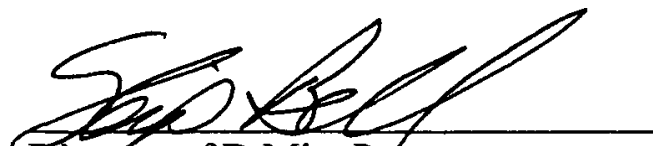

Direetor of D.Min. Program Skip Bell

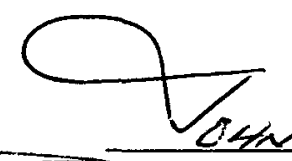

Dean, SDA Theologicar Seminary John McVay

\section{July 15,2002}




\section{TABLE OF CONTENTS}

LIST OF FIGURES $\ldots \ldots \ldots \ldots \ldots \ldots \ldots \ldots \ldots \ldots$ vii

ACKNOWLEDGMENTS $\ldots \ldots \ldots \ldots \ldots \ldots \ldots \ldots$ viii

Chapter

1. INTRODUCTION $\ldots \ldots \ldots \ldots \ldots \ldots \ldots \ldots \ldots \ldots$

Statement of the Problem $\ldots \ldots \ldots \ldots \ldots \ldots \ldots \ldots 2$

Statement of the Task ................. 2

Background and Justification for the Project . . . . . . . 2

Delimitations ................... 3

Definitions of Terms .............. 4

Overview of the Dissertation . . . . . . . . . . 6

2. LATVIAN SOCIETY AND CULTURE $\ldots \ldots \ldots \ldots \ldots \ldots$

General Information $\ldots \ldots \ldots \ldots \ldots \ldots \ldots \ldots$

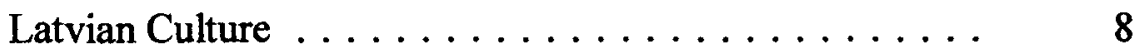

History .................. 8

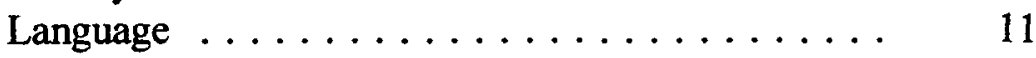

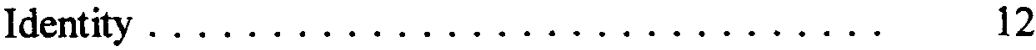

Latvian Society ..................... 14

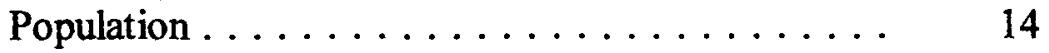

Education ............... 16

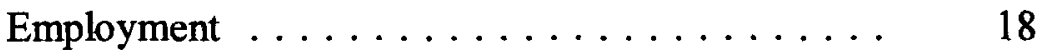

Health and Welfare .................. 20

Public Health and Its Promotion . . . . . . . . . . 21

Health and Welfare Institutions . . . . . . . . . . 25

Primary Health Care ................ 25

Hospitals . . . . . . . . . . . . . 26

Retirement Homes ................ 27

Religion in Latvian Society and Culture . . . . . . . . 28

First Half of the Twentieth Century . . . . . . . . . . $\quad 28$

Second Half of the Twentieth Century . . . . . . . . 31

At the Threshold of the Millennium ........... 33 
Evangelism before World War II . . . . . . . . . . 37

General Background of Adventist Church . . . . . . . . $\quad 37$

Suži Mission Seminary . . . . . . . . . . . . 40

Literature . . . . . . . . . . . . . . 41

Colporteurs . . . . . . . . . . . . . . 42

Bible Groups . . . . . . . . . . . . . . . 43

Evangelistic Meetings ................ 44

The Church during the Soviet Era . . . . . . . . . . . 44

Restored Freedom for Evangelism . . . . . . . . . . . 48

Public Evangelism . . . . . . . . . . . . . . 48

Bible Classes . . . . . . . . . . . . . . . . . $\quad 50$

Prison Ministry $\ldots \ldots \ldots \ldots \ldots \ldots \ldots \ldots \ldots \ldots$

Literature Evangelism . . . . . . . . . . . . . $\quad 52$

Radio Broadcasting . . . . . . . . . . . . 53

Opportunities for Pastors' Education . . . . . . . . 53

Growth in Numbers . . . . . . . . . . . . 55

4. A BIBLICAL FOUNDATION FOR WHOLISTIC HEALTH

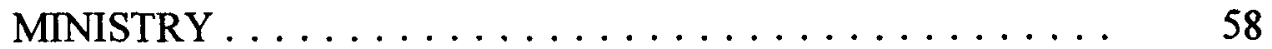

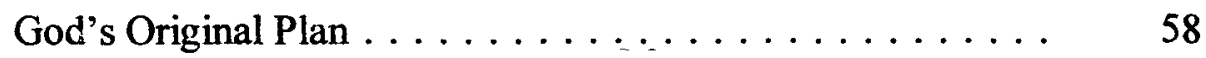

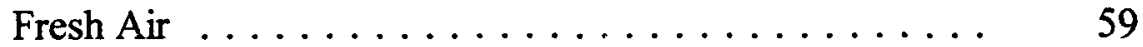

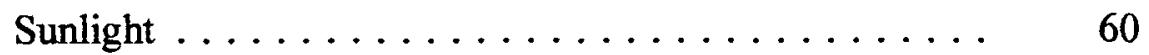

Pure Water . . . . . . . . . . . . . . 61

Exercise ................... 62

Proper Diet . . . . . . . . . . . . . . . 63

Periodic Rest . . . . . . . . . . . . . . . . . 64

Temperance ................... 64

Trust in God ....................... 65

Health Teachings from the Old Testament Period ...... 66

Sickness and Healing $\ldots \ldots \ldots \ldots \ldots \ldots \ldots . \ldots \ldots$

Natural Healing . . . . . . . . . . . . . $\quad 69$

Preventive Healing ................ 70

The Greatest Physician . . . . . . . . . . . . $\quad 71$

Health Teachings from the New Testament Period . . . . . . . 73

Medical-Missionary Work of Christ . . . . . . . . . . . 74

Christ's Commission to His Disciples . . . . . . . . . $\quad 77$

Medical-Missionary Work of the Apostles . . . . . . 78

5. HISTORICAL DEVELOPMENT OF SEVENTH-DAY ADVENTIST HEALTH EVANGELISM WORK $\ldots \ldots \ldots \ldots$

Background: Health Practices in the Early Nineteenth

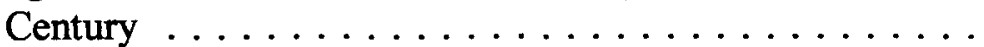




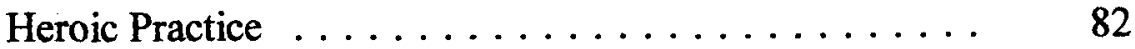

Theories of Disease . . . . . . . . . . . . 84

Sylvester Graham . . . . . . . . . . . . . 87

The Adventist Movement and the Role of Ellen G. White . . . 89

Early Adventists before $1863 \ldots \ldots \ldots \ldots$. . . . 89

Changes after E. G. White's 1863 Health Vision .... . 93

Adventist Concepts of Wholistic Health Ministry .... . . . 95

Approaches Used by Adventists . . . . . . . . . . . 95

Health and Wholeness . . . . . . . . . . . . 97

Step-by-Step in Health Evangelism . . . . . . . . . . $\quad 98$

Adventist Medical Missionary Work in Europe . . . . . . . 103

Health Work in Great Britain . . . . . . . . . . . . 104

Ellen G. White in Switzerland . . . . . . . . . . . . 106

The Temperance Movement in Norway . . . . . . . 108

6. A PROGRAM FOR HEALTH EVANGELISM IN LATVIA . . 111

Description of the Program . . . . . . . . . . . . 113

Every Church a Training Center . . . . . . . . . . 113

Seminars on the Eight Essentials of Health . . . . . . 114

Seminars on Hydrotherapy . . . . . . . . . . 115

Cooking Schools . . . . . . . . . . . . 116

Seminars on Stress Management $\ldots \ldots \ldots \ldots . .117$

Prayer Healing Ministry . . . . . . . . . . . . . 118

Other Health Promotional Actions . . . . . . . . . . 119

The Church's Public Outreach . . . . . . . . . . . 120

Health Food Restaurants . . . . . . . . . . . . . . 121

Evangelistic Campaigns and Health Promotion . . . . 122

Medical Institutions . . . . . . . . . . . . . 122

Medical or Dental Clinic . . . . . . . . . . . . 122

Nursing Home . . . . . . . . . . . . . . . . . . 123

Self-Supporting Health Ministries . . . . . . . . . 124

Implementation of the Program . . . . . . . . . . . 125

Implementation of the Church Training Seminars . . . . . 127

Prayer Healing Ministry . . . . . . . . . . . . 128

Seminars on Stress Management . . . . . . . . . . . 129

Cooking Schools . . . . . . . . . . . . . . . 130

Seminars on Hydrotherapy . . . . . . . . . . . . 131

Seminars on the Eight Essentials of Health . . . . . . . 132

Implementation of the Church's Public Outreach

Activities . . . . . . . . . . . . . . 132

Health Food Restaurants . . . . . . . . . . . . . . 133

Evangelistic Campaigns and Health Promotion . . . . . 134

Establishing Medical Institutions . . . . . . . . . . . . 135

Medical or Dental Clinic ............. 135 
Nursing Home $\ldots \ldots \ldots \ldots \ldots \ldots \ldots$

Self-Supporting Health Ministries . . . . . . . 137

Evaluation of the Program . . . . . . . . . . . . 138

7. SUMMARY, CONCLUSIONS, AND RECOMMENDATIONS . . 142

Summary . . . . . . . . . . . . . . . . . 142

Conclusions . . . . . . . . . . . . . . . 147

Recommendations . . . . . . . . . . . . . . . . . 149

APPENDIX: MAPS $\ldots \ldots \ldots \ldots \ldots \ldots \ldots \ldots \ldots \ldots \ldots \ldots \ldots \ldots$

Map of the Baltic States . . . . . . . . . . . . 152

Map of Latvia . . . . . . . . . . . . . . 153

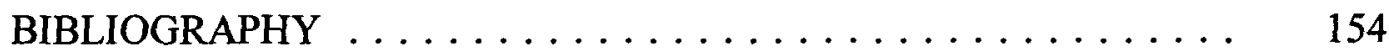




\section{LIST OF FIGURES}

1. Latvian Population, in Thousands . . . . . . . . . . . 14

2. Latvian Population by Educational Attainment $\ldots \ldots \ldots \ldots$

3. Unemployment Rate $\ldots \ldots \ldots \ldots \ldots \ldots \ldots \ldots . \ldots . \ldots$

4. Number of HIV Cases by Age Group and Sex $\ldots \ldots \ldots \ldots 23$

5. Church Membership of Latvian Conference $(1921,1929,1934) \ldots \quad 38$

6. Year-Ending Church Membership of the Latvian Conference (1936-1941) ........................ 39

7. Year-Ending Church Membership of the Latvian Conference

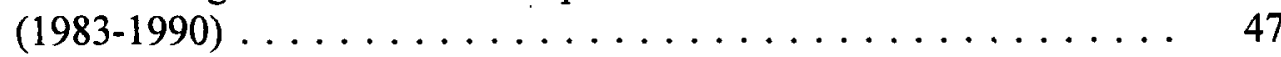

8. Year-Ending Church Membership of the Latvian Conference

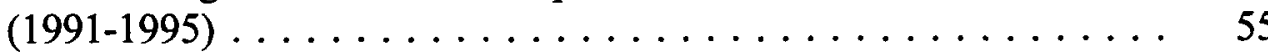

9. Year-Ending Church Membership of the Latvian Conference

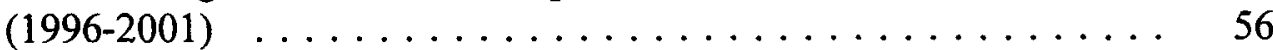




\section{ACKNOWLEDGMENTS}

There is no way I can adequately thank the Lord, who gave me the opportunity to fulfill what I could not even dream of. He led me step by step, gave me the desire and opportunities to start and finish this dissertation, blessed me with good health, and was right at my side at every moment.

This project has also been completed with the contribution, support, prayers, and counsel of many people. First I would like to express my deep appreciation to the members of my advisory committee, especially to Dr. Moon who was always available and helpful to read the earlier drafts, make the necessary changes, and supply many helpful ideas.

I am grateful for the unsolicited generosity of our dear family friends, Gordon and Marjorie Franklin. They provided tremendous financial help and kept my family and me in their daily prayers. I also extend a hearty handshake to dear friends at home, Viktors and Vesma Geide. They supplied me with much-needed books, copies of magazines, and other Latvian literature. Thanks, also, to the Currie family from Australia, the Colon family from Washington State, and many other friends.

My profuse gratitude goes to my loving Mom and my precious children, Andrejs and Estere. They supported me at every step and every day with their love, prayers, and much care. Finally, my sincere thanks go to my dearly beloved 
husband and life friend, Eriks. He has been a source of vision, support, and encouragement throughout the researching and writing of this dissertation. Often through faith he saw what I could not see, and helped me look forward to when this project would be done not only on paper, but also in the life of the Adventist church in Latvia. 


\section{CHAPTER 1}

\section{INTRODUCTION}

Jesus commanded His disciples to "go into all the world and proclaim the good news to the whole creation" (Mark 16:14). This command gave to all Christians a sense of responsibility and a call for urgency. For this reason the Seventh-day Adventist (SDA) church, ${ }^{1}$ as "a prophetic movement called to prepare a people in all parts of the earth to be ready for Christ's appearance," does the work of God's ambassadors for the salvation of people. The Lord organized this church for service and gave to it the mission of evangelizing the whole world by many different ways, ${ }^{3}$ including health evangelism. ${ }^{4}$ The Latvian Conference, ${ }^{5}$ as

${ }^{1}$ The HarperCollins Dictionary of Religion (1995), s.v. "Adventists."

${ }^{2}$ H. K. LaRondelle, "The Remnant and the Three Angels' Messages," Handbook of Seventh-day Adventist Theology Commentary Reference Series, vol. 12 (Hagerstown, MD: Review and Herald, 2000), 887.

${ }^{3}$ R. P. Lehmann, "The Second Coming of Jesus," Handbook of Seventh-day Adventist Theology Commentary Reference Series, 911.

${ }^{4}$ D. S. Williams, K. Kuzma, and L. R. Van Dolson, Ministries of Health and Healing (Silver Spring, MD: North American Division of the SDA Church, 1997), 59.

${ }^{5}$ N. J. Vyhmeister, "Who Are Seventh-day Adventists?" Handbook of Seventh-day Adventist Theology Commentary Reference Series, 18. 
a part of this unique world movement, ${ }^{1}$ also carries out the responsibility of evangelizing the Latvian community.

\section{Statement of the Problem}

Church leaders have regarded proclamation evangelism in the SDA church in Latvia as the main method in reaching people for Christ. Since 1995, however, this method apparently has lost much of its effectiveness. There is a need to develop other methods for reaching the Latvian population with the good news. One possible approach that deserves serious consideration is that of health evangelism. This kind of evangelism has had great success in other parts of the world, ${ }^{2}$ but has not been fully attempted in Latvia.

\section{Statement of the-Task}

The task of this dissertation is to design a program with some guidelines and suggestions for the development of SDA health evangelism in Latvia.

\section{Background and Justification for the Project}

Since the fall of communism and the liberation of the country in August of 1991 the SDA church in Latvia has gone through socio-political and economic changes which have made an impact on church growth, evangelism, and the church membership. However, SDA health evangelism with its multiple varieties

\footnotetext{
${ }^{1}$ Ibid., 13.

.$^{2}$ Global Partners (Loma Linda, CA: Loma Linda University and Medical Center, 1996), videocassette. See also Errol A. Lawrence, "The Medical Missionary Work of the SDA Church and Its Effect on the West African Union Mission," Term paper; Adventist Heritage Center, James White Library, Berrien Springs, MI, 1991, 35.
} 
of life-changing programs and institutions through the power of Jesus Christ has not been completely implemented in Latvia.

Health education, as a dimension of medical evangelism, involves, in itself, the cooperation of concerned people, a variety of official and voluntary agencies, and a church in promoting necessary changes in order to achieve optimum health and safety. ${ }^{1}$ This type of evangelism, which meets people's needs, has not been considered in the Latvian SDA church.

Many local pastors and lay members in Latvia today do not fully understand Ellen G. White's clear statement that "into the medical-missionary work should be brought a deep yearning for souls."2 There is a need for education about the cooperative working relationship that should exist between the winning of souls and the health message, where emphasis is on the spiritual nature of soul winning with consideration also given to the social, physical, and emotional dimensions of salvation. ${ }^{3}$

\section{Delimitations}

Even though this study is comprehensive, several delimitations should be mentioned. The study will provide a general survey of the historical period of evangelism and church growth in the Latvian SDA church, with more detailed emphasis on the last decade of the twentieth century.

\footnotetext{
${ }^{\text {I}}$ Williams, Kuzma, and Van Dolson, 22.

${ }^{2}$ Ellen G. White, The Ministry of Healing (Boise, ID: Pacific Press, 1988), 72.

${ }^{3} \mathrm{P}$. Gerard Damsteegt, Foundations of the Seventh-day Adventist Message and Mission (Berrien Springs, MI: Andrews University Press, 1995), 229.
} 
Today the SDA church has health evangelistic work all over the world with a variety of church-sponsored and self-supported activities such as seminars, clinics, hospitals, and sanitariums. This study, however, makes only a general survey of the origins and practice of health evangelism in North America and Europe, with special attention paid to the development of such work in Latvia.

The proposed program for health evangelism in Latvia envisions several different types of seminars and workshops. Also proposed are several medical institutions, which represent more advanced steps in health evangelism that could be implemented eventually, depending on economic and political circumstances.

All Scripture quotations are from the New Revised Standard Version, unless otherwise noted.

\section{Definitions of Terms}

The major terms frequently used in this dissertation are "wholistic," "medical missionary work," "health reform," and "preventive healing."

The term "holistic" has become associated with a variety of health concepts and practices that are associated with the New Age movement. V. N. Olsen, previous president of Loma Linda University, warned that the "holistic" approach "may bring pagan or non-Christian spiritual and religious values to the center of our endeavors," and described it as "the greatest attack of satanic power on the very center of the redemptive work of Christ." He continues, "The present popular movement for wholeness speaks about holism (without "w"). For the abovementioned reasons we, with others, call our objectives wholism (spelled with a 
"w")." Therefore, this dissertation uses the spelling 'wholistic' when referring to the biblical or Adventist concepts to distinguish these ideas from the New Age 'holistic' concepts. ${ }^{2}$

The term "medical missionary work" is the term usually used in the writings of E. G. White and other SDA authors to describe health evangelism. The term "health reform" stands for SDA beliefs in the area of health. However, this original name has acquired negative connotations because of overzealous practitioners and because the meaning of the word 'reform' has changed since the 1960s. No other single term has gained sufficient popularity in recent years. On the other hand, T. R. Flaiz has written an excellent definition of "health reform." He suggests that "health reform in its broader aspects is a plan for life by which our spiritual, intellectual, and physical bodies and powers are maintained at their highest potential of effectiveness, for a more abundant and joyous life, an honor to our Creator, and fit dwelling place for His Holy Spirit."”

The term "preventive healing" stands for protecting good health in a human body and improvement of chances to prevent or survive serious medical problems. The term includes in itself health education with an emphasis on healthful living.

\footnotetext{
${ }^{1}$ V. N. Olsen, "Wholistic Health--the Adventist Slant," Adventist Review, 19 January $1984,7,8$.
}

${ }^{2}$ For further study see Jack Gordon, "Training Terms: What Does Wholistic Mean?" Training Magazine, September 1987, 66; quoted in Russel Chandler, Understanding the New Age (Dallas, TX: Word, 1988), 162.

${ }^{3}$ T. R. Flaiz, "Our Bodies a Living Sacrifice," in Our Firm Foundation, 2 vols. (Washington, DC: Review and Herald, 1953), 2:359. 


\section{Overview of the Dissertation}

This study consists of extensive research and a proposed design for implementing SDA health evangelism in Latvia. The dissertation is divided into seven chapters, where chapter 1 introduces to the reader the background of the research, states the problem and the task, justifies the purpose of the study, and explains the overview of the organized work.

Chapter 2 acquaints the reader with Latvian society and its culture. It presents the period of the twentieth century with its two dimensions of political impact. The last part of the chapter describes the present Latvian society with its religion and culture.

Chapter 3 explores SDA evangelism in Latvia. Graphs and statistics trace the three main stages of Latvian evangelism: the period before World War II, during the Soviet era, and throughout the last decade of the twentieth century. Chapter 4 gives the biblical foundation for a wholistic health ministry. It describes the Edenic health rules, the human degradation after the Fall, and God's continuing willingness to restore human beings to spiritual, emotional, and physical health.

Chapter 5 presents the historical background of health evangelism and its development in the SDA church. It investigates the role of Ellen G. White and her writings about medical missionary work. The chapter also describes general aspects of Adventist concepts of wholistic health ministry as realized in North America and Europe. 
Chapter 6 is the culmination of the whole study. The proposed program, which is described there, gives guiding principles for organizing health evangelism in the country. It has been designed for the purpose of involving the whole Latvian SDA church with its leaders and lay members in the task of reaching people with the health evangelistic message. The reader will find in the chapter a suggested strategy for implementation and evaluation.

The last chapter summarizes the work done, presents conclusions, and provides recommendations for the implementation of the proposed health evangelism in the Latvian setting. 
CHAPTER 2

\section{LATVIAN SOCIETY AND CULTURE}

To develop and propose a program for health evangelism in Latvia, one has to be acquainted with the local population, people's lifestyle, their needs, health and welfare system in the country, and also religion and beliefs of the nation. This chapter presents the main aspects and characteristics of Latvian society and culture.

\section{General Information}

Latvian Culture

\section{History}

Latvia is a small European country, which lies on the Eastern coast of the Baltic Sea. It has a culture and traditions that are centuries old. Baltic tribes first made the Latvian land their home sometime during the first half of the second millennium BC. ${ }^{1}$ In the twelfth century A.D., the independent evolution of the tribes and communities living in this territory was shortened by the arrival of western European (mostly German) crusaders traveling east and spreading the

\footnotetext{
l"History," <http://www.randburg.com/lv/history.html $>$ (accessed 11
} September 2001). 
Catholic faith and the expansion of feudalism. ${ }^{1}$ Thus economical and cultural ties were developed between local people and neighboring Europeans.

The beginning of the nineteenth century heralded the onset of the consolidation of the Latvian nation, when Latvians first began to consider themselves as members of a viable separate nation. ${ }^{2}$ By the end of the nineteenth century, the Russian government had begun a program of deliberate 'Russification', which endangered the autonomy of the Balto-Germanic provinces and the rapidly increasing nationalistic movements. ${ }^{3}$

Before the Latvian Republic was established on November 18, 1918, and before it gained independence, the country was in a very hectic stage. The revolutions of 1905 and 1917 in Russia, World War I, and the battle for independence left an indelible mark on the history of Latvian culture. It was a time of sufferings and battles that led to eventual liberty. ${ }^{4}$

In 1939, Latvia fell under Soviet dominion and because of this new political situation, tens of thousands of Latvia's population were deported to Siberia. The years of World War II were marked as the time of destruction and

${ }^{1}$ Gunārs Kurlovics and Andris Tomasuns, Latvijas Vēsture (The History of Latvia) (Riga, Latvia: Zvaigzne ABC, 2000), 44.

${ }^{2} \mathrm{Ibid}$.

3"History, Language, Identity and Culture of Latvia," $<$ http://www.lettland.nu/info/latvia.identity.html $>$ (accessed 11 September 2001).

${ }^{4}$ Artūrs Priedītis, Latvijas Kultüras Vẽsture (The History of Latvian Culture) (Daugavpils, Latvia: A.K.A., 2000), 185. 
demolition, especially for the Latvian Jewish population. ${ }^{1}$ By the end of World War II about 250,000 of the Latvian intelligentsia had emigrated from the country. ${ }^{2}$ During that time, all of Latvia's ethnic groups suffered from the communistic terror, genocide, the war, and concentration camps.

During the Soviet occupation, Latvian culture found itself under the strong pressure and influence of totalitarianism, which became the determinative characteristic of life. Strongly emphasized were ideas such as 'soviet man,' 'socialistic way of life,' and 'unity of soviet cultures'. ${ }^{3}$ All Latvian holidays that were related to Christianity and church rituals were forbidden to celebrate and were changed into different kinds of holidays. Religion was taken out of the mind of Latvians.

Latvia regained her independence at the time of the collapse of the Soviet Union in August 1991. Now the government could restore Latvia's pre-war status and re-establish diplomatic relations with the Western democracies.

Today Latvia's people live in a country that has gone through a period of economic and political restoration. ${ }^{4}$ Latvia's culture is in a time of renovation. As the philosopher Nikolai Roerich said, culture in the circle of art, science, and

\footnotetext{
${ }^{1}$ Ibid, 191. During WWII about 61,000 Jews were killed in Latvia.

${ }^{2}$ Ibid., 193.

${ }^{3}$ Ibid., 192.

${ }^{4}$ Kurlovics and Tomasuns, 287.
} 
religion is the key to harnessing the diversity of origins and beliefs of many

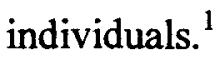

\section{Language}

Language is one of the determining factors of national identity. Without language for communication, there would be little or no science, religion, commerce, government, art, literature, and philosophy. ${ }^{2}$ The Latvian language is part of the Baltic branch of the Indo-European language family. Having developed a rich lexicology and a standardized grammar, it meets the needs of a modern society. However, after the Soviet takeover, all Latvians had to learn Russian, which became the official language of government, business, and the mass media. During the fifty years of occupation a whole generation was raised knowing mostly only the Russian language. At that time the Latvian language had nearly become extinct.

Therefore, during the national re-awakening in the late 1980s, the fight for the survival of the Latvian language became a rallying point for many Latvians. In October 1988, while Latvia was still an illegally annexed republic of the Soviet Union, Latvian was declared the state language and on May. 5, 1989 the Language Law was passed. ${ }^{3}$ Even though the implementation of the Law was gradual, for

\footnotetext{
1"Facts About Latvian History," $<$ http://www.cc.jyu.fi/ wlad/latvia/latvia.html $>$ (accessed 11 September 2001).

${ }^{2}$ The World Book Encyclopedia, 1996 ed., s.v. "Language."

3،History, Language, Identity and Culture of Latvia," Internet.
} 
the almost 670,000 non-Latvians in the country ${ }^{1}$ it became a traumatizing factor, especially for the older non-Latvian population. ${ }^{2}$ For these reasons, the proposed health evangelism program would need to have materials and leadership instructions provided in both Latvian and Russian languages.

\section{Identity}

From old times until today Latvians have lived very close to the natural world. The geographical environment, nature, and climatic conditions strongly influenced the character and spirit of the nation. The people's way of life, work traditions, customs, food, clothing, and festivals all reflect, in one way or another, the beauty, character, and processes of nature.

Latvia's culture was originally that of an agricultural people who were born in individual farms and not in villages. Today, however, because of agricultural industrialization the number of people living in farms has sharply diminished. In $1863,85.2$ percent of the total Latvian population lived in farms, but in 1997 the figure had dropped to only 31 percent. ${ }^{1}$

But in spite of the rapid process of urbanization, the Latvian people still have a tendency to obtain a small plot of land outside a city for gardening or just simple relaxation. It shows that the nation has a deep-seated love and longing

\section{${ }^{1}$ Ibid}

${ }^{2}$ According to the 1989 census, only 52 percent of Latvians lived in the country. In 1994 estimates of Latvian and Russian groups were 54.2 percent and 33.1 percent, respectively. For additional information see "Latvia" $<$ http://memory.loc.gov/cgi-bin/query/r?frd/cstdy:@field(DOCID+lv0008)> (accessed September 6, 2001). 
towards nature, land, and being in harmony with them. It also signifies of actual health evangelism possibilities that must work in harmony with nature in order to restore human health.

Latvians identify themselves as the culture of choirs singing together. Once in every five years, a united choir of twenty thousand or more singers performs on the stage of Mežapark in Riga. ${ }^{2}$

Twentieth-century Latvian culture is also known as the "green land" apologetic. ${ }^{3}$ It describes the land as the source of strength and life for the nation. Private property of land is pointed out as the social, material, and cultural guarantee of independence and the precondition of the nation's prosperity and wealth. The above-mentioned elements find their expression in Latvian folklore, especially folk songs, and also in literature, poetry, art, and dances.

Though this health evangelism proposal does not include music as a separate point, however, spiritual and classical music, as one of the most powerful mediums positively effecting moods and dispositions of people, could be used as an avenue, especially in dealing with mental health problems. Good melodious music by its nature is a bonding agent that transcends cultural and church boundaries.

${ }^{1}$ Priedīis, 198. 10.

${ }^{2}$ G. Pelēkais et al., eds., Latvija (Latvia) (Riga, Latvia: SIA «LKS», 1997), ${ }^{3}$ Ibid., 204. 


\section{Latvian Society}

\section{Population}

Latvia is not only a small country in territory, but also its population decreases with every year. For example, according to the 1989 census, the country contained 2,680,029 people. ${ }^{1}$ By 1994 , the population had declined to $2,565,854 .{ }^{2}$ At the beginning of 2001, the Central Statistic Bureau estimated only $2,366,400$ Latvian residents. ${ }^{3}$ See fig. 1

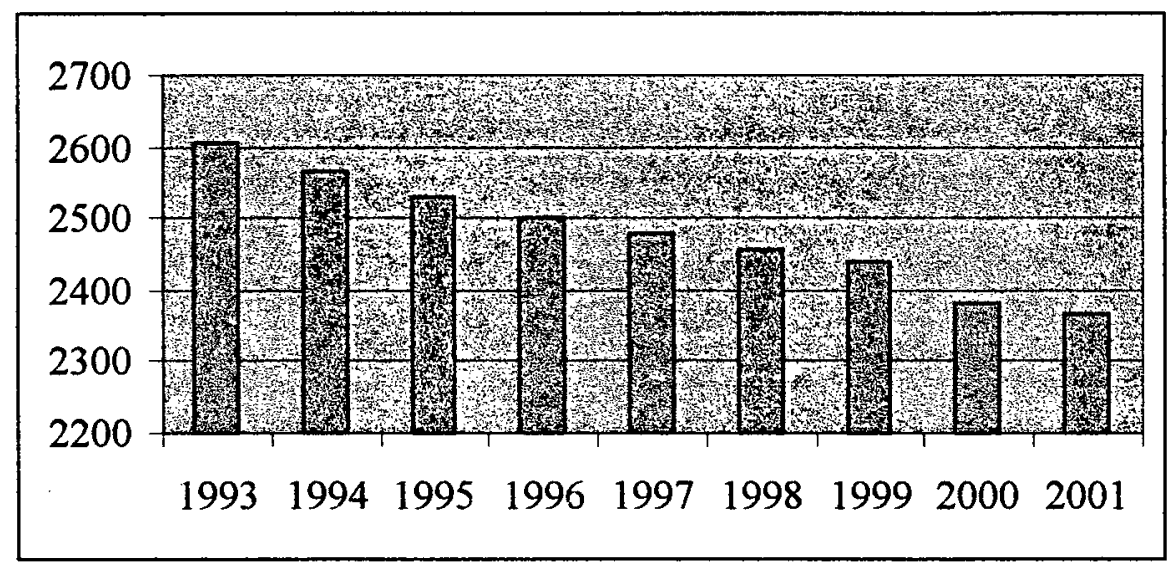

Fig. 1. Latvian population (at the beginning of the period), in thousands From "Population," Basic Socio-Economic Indicators, $<$ http://www:csb.lv/Satr/rad/C1.cfm?akurs3=C1> (accessed 31 August 2001).

${ }^{1}$ The WB Encyclopedia, s.v. "Latvia."

2"Latvia," $<$ http://memory.loc.gov/cgibin/query/r?frd/cstdy:@field(DOCID+lv0008) $>$ (accessed 6 September 2001).

${ }^{3}$ Uldis Usackis, "Latvijas Iedzīvotāju Skaits Turpina Samazināties" (The Population of Latvia Continues to Decrease), $<$ http://www.csb.lv/lteksts.cfm?tem_kods=dem\&datums $>$ (accessed 7 September 2001). 
One of the main reasons for the decline of the population during these years is a net out-migration and negative natural growth. In regard to natural growth, the latest data show that in Latvia in 2000 the number of abortions surpassed the number of newborn babies by almost 2,000 , according to the Central Statistic Bureau of Latvia in its bulletin, "Children in Latvia 2001." From January to July 2001 , the birth and death rates were the following: 4.3 newborn babies and 7.1 deaths per thousand population. That means that during only the first half of 2001, the Latvian population declined by almost 8,800 persons. ${ }^{2}$

One of the very important segments of a population is the family. Latvian families view their lives today as busier, more complex, and more challenging that they were ten years ago, just before the restoration of Latvia's independence. ${ }^{3}$

The pressure of balancing schedules and resources to achieve economic security lies on the family. Thanks to old family traditions, there is a strong bond between generations. In most families where both parents are forced to work, it is the grandmother who assumes the main responsibility for maintaining the household and looking after the children.

1"'Pērn Latvijā Abortu Skaits Par Gandrīz 2000 Pārsniedzis Jaunpiedzimušo Skaitu" (Last Year the Number of Abortion Surpassed the Number of Newborn Babies by Almost 2,000), <http://www.leta2000.com> (accessed 9 September 2001). In 2000, 20,248 babies were born and 22,201 were aborted.

${ }^{2}$ Usackis, Internet.

3"The Contemporary Latvian Family," <http://www.latinst.lv/family.htm> (accessed 7 September 2001). 
At the same time, most Latvian couples do not stay married longer than ten to twelve years. ${ }^{1}$ The percentage of divorces is very high. In 1996, there were 628 divorces per 1,000 marriages and in 2000, there were 666 divorces per 1,000 marriages. ${ }^{2}$ Most of these broken families have underage children, for which it is very difficult for separated parents to provide a good education.

As fundamental and complex the problems may be, here is the opportunity for Adventist church to become involved and minister with health evangelism. Under these circumstances health evangelism program can leave the greatest impact on human lives by presenting to people the basics of the sanctity of a human life, destructive consequences of abortions, sacredness of marriage establishment, and how to cope with and overcome family dilemmas from the biblical perspective.

\section{Education}

For some people, the Latvian educational system may seem to be out of the ordinary because of the diversity in the national schools. During the $1960 \mathrm{~s}$ new schools were introduced with two languages of instruction, Latvian and Russian. Each group of children held classes in its own language. There were also purely Latvian or Russian schools. After Latvia got independence in 1991, various ethnic groups opened schools in their own language of instruction. Next to

\section{${ }^{1}$ Uldis Usackis, "Turpina Samazināties Noslēgto Laulību Skaits" (The} Number of Registered Marriages Continues to Decrease), <http://www.csb.lv> (accessed 17 September 2001).

${ }^{2}$ Ibid. 
Latvian and Russian schools today in Latvia are Polish, Estonian, Lithuanian, Ukrainian, and Jewish schools.

All children in Latvia must complete nine years of primary schooling, which may be followed by three years of secondary education or one to six years in technical, vocational, or art schools. According to basic socioeconomic indicators, in 2000 there were in Latvia 1,074 general schools with an enrollment of 359,818 students (in 1995 there were 1,094 schools with 347,541 students). ${ }^{1}$

People can get a higher education in one of the high educational institutions or universities, the largest of which is the Latvian State University in Riga. Today there are 33 such institutions with 101,270 students enrolled (in 1995 there were 28 institutions with 46,696 students). ${ }^{2}$ See fig. 2 .

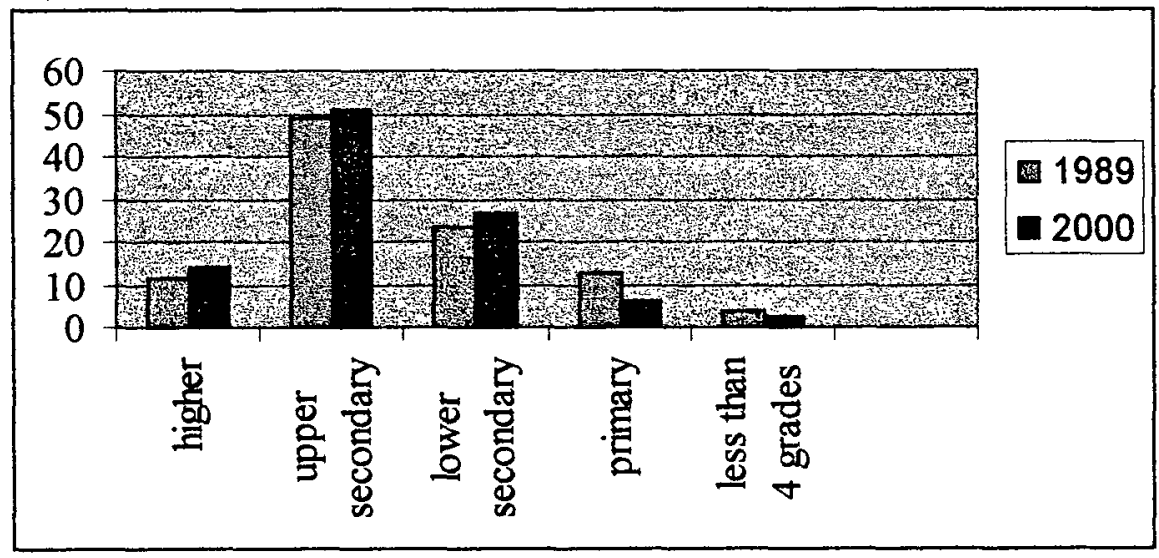

Fig. 2. Latvian population by educational attainment (percentage of total). From "More Than Half of the Population of Latvia has Secondary Education," $<$ http: $/ /$ www.csb.lv.ateksts.cfm?tem kods=tsk\&datums $>$ (accessed 18 September 2001).

l'"General Schools," <http://www.csb.lv/Satt/rad/Mla.cfm?akurs03=M1a > (accessed 18 September 2001).

${ }^{2}$ Ibid. 
The Latvian Ministry Cabinet has a goal to provide education for all children in the country. Unfortunately, not all children go to school. In September 1997, the Ministry of Science and Education had records of 1,311 children ages 715 who were not attending school. ${ }^{1}$ Usually these are children who live in dysfunctional families where the value of education is not appreciated or children from families below the poverty level. In spite of these negative data, the literacy rate stands not far from 100 percent.

These statistical data has great value for planning different health evangelism aspects. Miscellaneous books, magazines, and pamphlets on a variety of health topics can be distributed among various strata of Latvian society thus keeping them not only informed but also educated in wholistic health issues.

\section{Employment}

In regard to employment in Latvia, all residents ${ }^{2}$ are allowed to work from age 15. Retirement age for men is 59 and for women is 56 . The rapid economic changes of the early 1990s have brought about an employment reorientation by

\footnotetext{
${ }^{1}$ Antra Mazura, "Education for All," $<$ http://www2.unesco.org/wef/countryreports/latvia/repport 2 2.html $>$ (accessed 20 September 2001).

2“"Before October 15, 1991, all residents of Latvia enjoyed equal legal status. On October 15, 1991, Latvian Parliament passed a Resolution on the Renewal of Rights of the Citizens of the Republic of Latvia and Fundamental Principles of Naturalization which divided the residents of Latvia into two major categories: citizens (approximately two thirds), and non-citizens (approximately one third). The criterion for citizenship was whether a person or the person's parents were Latvian citizens in 1940. The difference in their formal political status increasingly led to the differentiation in the Latvian residents' social, property, employment, and other 'non-political' rights." For additional information see $<$ http://www.lvnet.lv/HumanRights/Differences $>$.
} 
various ethnic groups. Latvians or citizens of the country mostly work in the culture and art departments, agriculture, public education, communications, administration, credit and state insurance companies, health care, and social security. The rest of the population works in industry, transport, and construction. ${ }^{1}$

For several years the country's unemployment rate has remained stable at 7.8 percent $(92.9$ thousand persons of the economically active population are considered as unemployed). ${ }^{2}$ At such a high rate of unemployment, finding a job is extremely difficult for young people, for people with disabilities, and for those who do not have a good educational background. See fig. 3 .

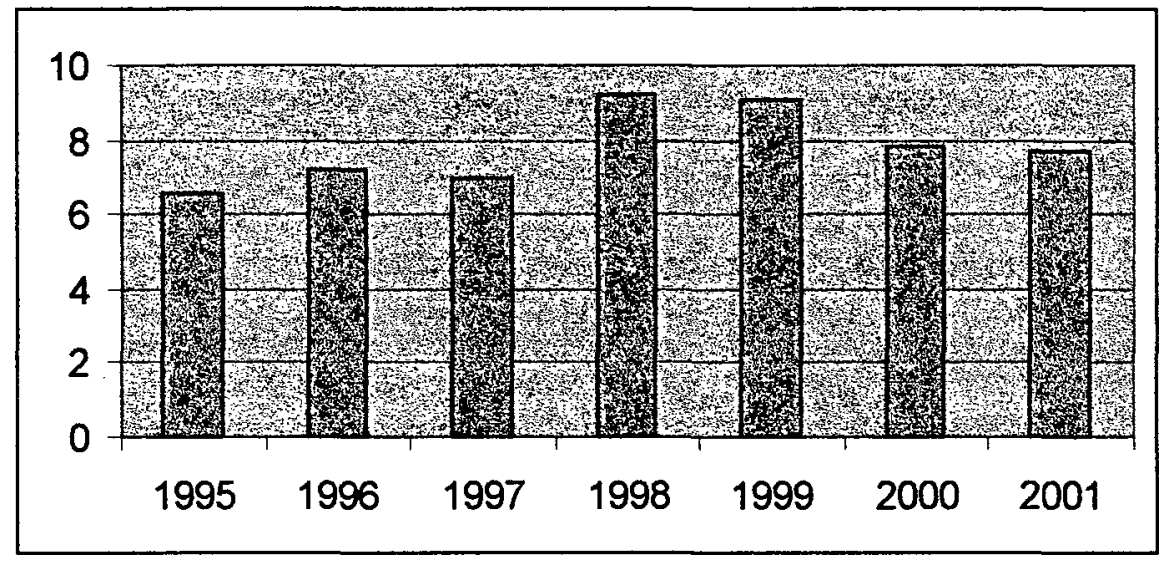

Fig. 3. Unemployment rate (percentage of total at the end of each year). From "Bezdarba Limenis" (The Level of Unemployment), Galvenie Sociālekonomiskie Rādîtāji (The Major Socio-Political Indicators), <www.csb.lv/Satr/rad/D3.cfm?kurs3=D3> (accessed 31 March 2002).

\footnotetext{
"Latvia: Urbanization, Employment, and Education," $<$ http://lcweb2.loc.gov/cgi-bin/query/r?frd/cstdy:@field(DOCID+lv0019) $>$ (accessed 10 September 2001).

2"The Unemployment Rate Remains Stable," $<$ http://www.csb.lv/ateksts.cfm?tem kods=bezd\%5Fv\&datums $>$ (accessed 18 September 2001).
} 
According to the results of the living conditions survey, the average net wages and salaries in 1999 for persons with higher education were LVL 156 (about \$290) per month and LVL 75 (about \$140) for persons with basic education. ${ }^{1}$ As of March 2000 the minimum wage was LVL 50 (about $\$ 80$ ). ${ }^{2}$

Finally, a productive economic system is the main precondition for providing the population with employment and an adequate standard of living, which is an indispensable element of a nation's prosperity. However, as was mentioned above, the transition of the political system and the drastic turn from central planning to a market economy have been attended by a serious economic and unemployment crisis.

These crises open before Adventists another way of presenting health message to the people by teaching them how to investigate their habits of diet, effects of various foods on their system, how to make wise choices, etc. Price wise such natural foods as vegetables, whole grains, and fruits are much cheaper, easier available, and healthier than meat products.

\section{Health and Welfare}

With the change of social and economic norms in the country, public health also feels this profound impact. Within the last years the health status of the Latvian population, including children and youth, has rapidly worsened. Until

\footnotetext{
'Edmunds Vaskis, "Living Conditions in Latvia," $<$ http://www.csb.lv/Pres/livcond1.htm> (accessed 18 September 2001).

2a"Labor Legislation," $<$ http://www.lda.gov.lv/index.php?b=18> (accessed 21 September 2001).
} 
recently, organized efforts to promote better health have played only a small part in the society.

Public Health and Its Promotion

The data regarding the negative population growth tell not only about the infant death rate and abortions, as mentioned above, but have much more to say. Statistics show that "only 7\% of Latvian school children have been found practically healthy. Shocking are the data on the life style of adolescents in Latvia: $27 \%$ of boys and $9 \%$ of girls are regular smokers, and only $36 \%$ are subjected to regular physical work. These indices are among the worst in Europe." 1

According to the 1993 survey, 67 percent of males and 12 percent of females were regular smokers. At the same time, smoking prevalence among physicians was 59 percent and 26 percent among nurses. ${ }^{2}$ Even though tobacco is not grown in Latvia, people buy cigarettes, ${ }^{3}$ smoke, and show a bad example to their children. By doing this, they put themselves and the surrounding society in greater danger of getting sick. Therefore, there is a unique chance for the church to present smoking cessation seminars.

1"Health Education," <http://www.who.dk/NEHAP/Lat/Lchap58.html> (accesses 10 September 2001). According to Dr. Neil Nedley, Eastern European men have the world's highest death rates from smoking. For more information see Neil Nedley, Proof Positive: How to Reliably Combat Disease and Achieve Optimal Health through Nutrition and Lifestyle (Ardmore, OK: Neil Nedley, 1999), 372.

2"'Tobacco or Health: A Global Status Report, Latvia," $<$ http://www.cdc.gov/tobacco/who/Latvia.html $>$ (accessed 6 September 2001).

3" At average earnings, about 77 minutes of labor were needed to purchase a pack of 20 cigarettes in the early 1990 s." Ibid. 
Because of wrong eating habits and unhealthy lifestyle, Latvia ranks with many other countries where diseases of the blood circulatory system are the most frequent cause of death. The second most frequent cause of mortality is malignant tumors, ${ }^{1}$ which is followed by unnatural deaths: traumas, transport accidents, and suicide. ${ }^{2}$ If a person lives without God, suicides are a symptom of an individual's inability to adapt oneself to the changing reality, which by its nature is destructive.

Tuberculosis is another common disease. It is more prevalent among males than females. In addition, rates of food poisoning and hepatitis A remain high. $^{3}$ Causes of these diseases include application for medical aid that is too late, self-treatment, application for quick aid, as well as a decrease in the frequency of medical examinations and preventive healing.

During the last few years the number of people with HIV and $\operatorname{AIDS}^{4}$ has rapidly increased in the country. In comparison with other countries, the number of AIDS cases in Latvia is still small, but increasing every year. In 1997, there were only three registered persons with AIDS. Two years later, that number was increased almost six times. In 2000, 24 new cases of AIDS were registered in the

\footnotetext{
${ }^{1}$ With years, cancer rates increase rapidly. For example, "in 1994 there were registered 307.2 cancer cases per 100,000 of population, in 1992 the number of cancer cases having been 291.4 only." Ibid.

${ }^{2}$ Ibid.

${ }^{3}$ Ibid.

4“"A person cannot get Acquired Immunodeficiency Syndrome (AIDS) unless they are infected with Human Immunodeficiency Virus (HIV). However, not all individuals with HIV infection will necessarily develop AIDS with its profound immune system weakness and accompanying symptoms. Even after 10 years, only about half of those infected with HIV have actually developed AIDS." Nedley, 347.
} 
country. ${ }^{1}$ The picture with HIV cases seems even worse. In 1997, only 25 new cases of HIV were registered. By the middle of September 2001, this number was increased to 591 new cases. By that date there were in Latvia 1,555 persons with HIV. See fig. 4.

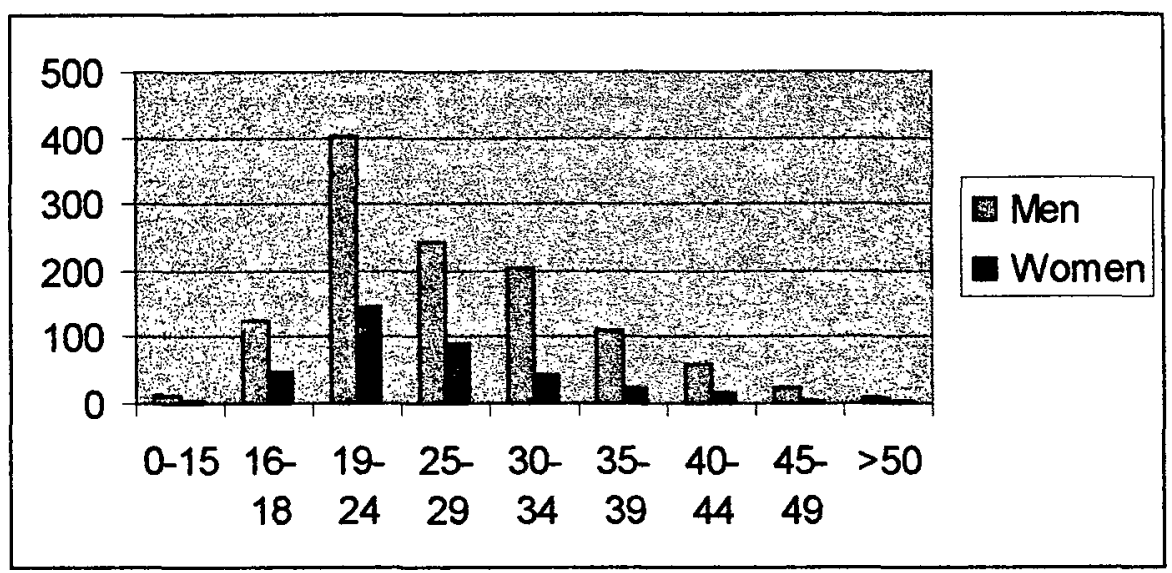

Fig. 4. Number of HIV cases by age group and sex. From "Number of HIV Cases by Age and Sex, September 15, 2001," $<$ http://www.aidslatvija.lv/Statistika/vecumi_1.htm> (accessed 23 September 2001).

At this mediocre level of public health in the country, health promotion is moving forward, in spite of the fact that it faces a number of problems. First, policy-making for public health promotion is not systematically established, and lacks vital skills and input as are present in more advanced European societies. Since social and economic development requires the concept, principles, and

"HIV/AIDS Cases by Year of Diagnosis, September 15, 2001," $<$ http://www.aids-Latvija.lv/Statistika/ikgad_ 1.html > (accessed 23 September 2001). 
strategies of health promotion to be at the heart of government business, these issues are still of serious concern. ${ }^{1}$

Second, there appears to be a widespread misunderstanding that primary health-care professionals, particularly family doctors, should carry most of the responsibility for "health promotion." There is no doubt that these professionals take upon themselves the main role of health promotion, but at the same time health promotion should actively engage many other sectors of society, broadened far beyond health-care services. Today, education and promotion of public health need to become one of the country's priorities.

The focus on reaching the Latvian community with health-promotion programs started in 1990, when a group of Latvian school teachers and physicians visited Boston and observed the teaching of health subjects at school. After that experience, many Latvian schools and universities started to teach health education. ${ }^{3}$ In 1994, the Department of Health formed a Unit of Health Promotion responsible for the development of coordinated programs of health promotion and disease prevention at both the national and regional levels. ${ }^{4}$

\footnotetext{
1"Public Health in Latvia with Particular Reference to Health Promotion," $<$ http://www.rhpeo.org/ijhp-articles/1998/6/> (accessed 6 September 2001).

${ }^{2}$ Tbid.

${ }^{3}$ In 1995 the Ministry of Welfare together with the Ministry of Education and Science published the magazine Sveiks and Vesels (Safe and Sound). This magazine is an educational aid on health issues for different ages of school children.

"Health Education," Internet.
} 
Besides schools, there are opportunities for health promotional work in many different sectors, such as the workplace, voluntary agencies, churches, and individual homes. However, until recently, organized efforts to promote better health have played only a small part in Latvian society. ${ }^{1}$ Much greater effort still needs to be made on the topic of health promotion in Latvian society.

Health and Welfare Institutions

\section{Primary Health Care}

Since Latvia regained its independence, both state-run institutions and private medical establishments and services provide health care for all residents of the country. Until the early 1990s, primary health care in cities and towns was provided only in polyclinics. ${ }^{2}$ During recent years more health-care providers began to operate more independently of the state and privatize their services. Thus, the number of family physicians increased from 27 in 1991 to 801 in $1999 .{ }^{3}$

${ }^{1}$ One such effort has been made since 1994, where the Ministry of Welfare, in collaboration with the World Health Organization (WHO) Mission in Latvia and Latvian Physician Society, has organized a Health Week, which involves various non-governmental organizations and representatives of mass media. Every day of the week has been dedicated to a concrete health problem, e.g., sexual health, mental health, oral health, healthy environment. During the event, various seminars and conferences on these topics have been organized, and the event course has been daily reflected by radio, television, and press. For more information, see WHO, "Latvia," <http://www.who.dk/NEHAP/Lat/Lchap58.htm> (accessed 10 September 2001).

${ }^{2} \mathrm{~A}$ polyclinic is a medical center where specialist physicians, dentists, nurses, and therapists provide health-care services.

${ }^{3}$ The rate of practicing physicians in 1999 was 313 per 100,000 population, which is lower than the European average (353 per 100,000 in 1997). WHO, "Highlights on Health in Latvia," 33, 36, $<$ http://www.who.dk/document/e72407.pdf> (accessed 8 October 2001). 
At the same time, the total number of nurses in the country decreased significantly, by 40 percent. $^{1}$

Between 1945 and 1991, health care in Latvia, as everywhere in the USSR, was planned and organized according to the Semashko model, where the state centrally planned the organization, management, and delivery of health-care services. All services were free of charge and accessible to all the population but private initiatives were restricted. ${ }^{2}$ Today the public health-care sector is mostly funded from general taxation. Local government provides very little financial support and each patient has to pay out of pocket 25 percent of doctor-visit fees. Only emergency care, maternity care, and treatment for those under 18 years of age are entirely free. ${ }^{3}$ At the same time, high class society prefers to visit doctors in private clinics. By establishing medical or dental clinic, Adventists would have an opportunity to reach these people.

\section{Hospitals}

In order to better perceive the total picture of health and welfare institutions in Latvia, it is necessary to mentions also hospitals. Most of them provide both in-patient and out-patient services. Private hospitals obtain their income from direct payments by patients and from contracts for specific services from regional sickness funds. In the public hospitals, hospital administration

\footnotetext{
${ }^{1}$ Ibid.

${ }^{2}$ Ibid., 32.

${ }^{3}$ Ibid., 33.
} 
requires patients to sign an agreement to pay the co-payment. The sickness fund pays the remaining expenses.

The number of hospital beds has rapidly decreased during the last decade. In 1992 , there were 130 beds per 10,000 inhabitants, ${ }^{1}$ but the number in 1999 was only about 89 beds, $^{2}$ which is still 32 percent higher than the European average (67 beds per 10,000 in 1998). ${ }^{3}$ The same can be said about the average length of hospital stay. In 1985, it was 18.2 days. By the 1999 , the average length of hospital stay had declined to 11.8 days. ${ }^{4}$

\section{Retirement Homes}

Currently in the country, 30 percent of the population are retired people. According to the Latvia Human Development Report, "107,822 lacked family support of any kind and 139,309 had family members who were either unwilling or unable to provide them with material assistance. Moreover, 12,579 persons were in need of home care and 1473 were confined to beds."

Municipal social aid services are doing their best to provide care for the elderly people, but, because of lack of finances, only 63 percent of those who

1"Latvia: Urbanization, Employment, and Education," Internet.

${ }^{2}$ WHO, "Highlights on Health in Latvia," 35, Internet.

${ }^{3}$ Ibid.

${ }^{4}$ Ibid., 36.

5“Latvia Human Development Report," Chapter 3, $<$ http://www.un.lv/down/1995 e/chapter3.html $>$ (accessed 3 October 2001). 
needed help got it in $1994 .^{1}$ Since then, the picture may have improved only slightly. The homes for the elderly people, which are run by Latvia's social security system, cannot accommodate everyone. On the other hand, many aged people are unwilling to live in the retirement homes. Many of these homes are in great need of funds for salaries, structural renovation, equipment, and sanitary materials. People in such homes lack any privacy. The rooms are usually shared by two or even more persons. In spite of the financial, ethnic, and other struggles, these homes provide only basic amenities such as food, clothing, shelter, and basic health-care needs.

Latvian Christian Mission, together with some other organizations, provides food, shelter, and other Christian spiritual guidance. ${ }^{2}$ The State Minister for Health in the Ministry of Social Welfare also has concerns about the health and welfare of the Latvian population. The Minister's responsibilities for implementing the government's health policy include improvement of the state-run retirement homes and the promotion of primary and preventive health care.

\section{Religion in Latvian Society and Culture}

First Half of the Twentieth Century

Religion in Latvia has a very colorful history of religious traditions.

Before World War II, during the years of independence, the country had four predominant Christian denominations, as well as Jews. Evangelical Lutheranism

\section{${ }^{1}$ Ibid.}

2"Latvian Christian Mission," <http://www.gospels.com/lcm.html> (accessed 3 October 2001). 
was the single most widespread creed, claiming the allegiance of 55.2 percent of the total population. ${ }^{1}$ In second place was the "oldest Latvian denomination," Roman Catholics, with 24.5 percent of the population. ${ }^{3}$ Catholics mostly lived in the economically less-developed southeast province of Latgale. Even today this remains the center of the Latvian Catholic Church.

The Orthodox Church claimed 9 percent of the population, ${ }^{4}$ mostly Russians and other Slavs. At the same time, many Russians in Latvia belonged to the Old Believers Church. ${ }^{5}$ Nearly 5.5 percent of the total population were Old Believers. ${ }^{6}$ Ancestors of these people came to Latvia in the seventeenth century, when they fled from persecution in tsarist Russia.

In Latvia also were large Jewish communities, which had been formed earlier than the sixteenth century. ${ }^{7}$ Before 1940,56 of Latvia's cities and small rural districts were home to about 300 synagogues and prayer houses. In those

${ }^{1}$ Walter R. Iwaskiw, ed., Estonia, Latvia, and Lithuania: Country Studies (Lanham, MD: Research Division, Library of Congress, 1996), 121.

${ }^{2}$ Ringolds Balodis, Valsts un Baznīca (Church and State) (Riga, Latvia: Nordic, 2000), 128.

${ }^{3}$ Iwaskiw, 121, 122.

${ }^{4}$ Ibid., 122.

${ }^{5}$ Old Believers are "Christians, who split from the Russian Orthodox Church in opposition to Patriarch Nikon's demand in 1652 that Russian liturgical practices conform completely to those found among the Greek patriarchates." The HarperCollins Dictionary of Religion (1995), s.v. "Old Believers."

${ }^{6}$ Ibid.

${ }^{7}$ Balodis, 326. 
years about 5 percent of Latvia's citizens were Jews. ${ }^{1}$ Christian Latvians and Jewish Latvians have a long history of harmony and good relations. Until World War II the Jews in Latvia had religious freedom and financial prosperity; but during the war about 75,000 Latvian Jews were killed by the Nazis.

The rest of the pre-World War II Latvian population was scattered among an array of Protestant denominations such as Baptists, Seventh-day Adventists, Methodists, and others. In the 1920s and 30s, Adventists in the Latvian society were considered to be a "foreign sect"; however, the church was included in the Civil Law which gave members legal marriage rights.

In 1919 Pēters Stučka, chairman of the Latvian National Council, proclaimed a total separation between church and state. ${ }^{2}$ Fifteen years later, in 1934, the Church Law recognized full freedom of.religion, "any group of 50 citizens being entitled to register as a denomination, and ten of such denominational groups being sufficient to form a nationál religious association. No single denomination was given special privileges or protection. All came under the supervision of the Department of Religious Affairs of the Ministry of the Interior."3

During Latvia's independence period, religious education was required for all schoolchildren. It was one of the most important subjects. Four main Christian

${ }^{1}$ Ibid.

${ }^{2}$ Ibid., 126.

${ }^{3}$ Alfred Bilmanis, A History of Latvia (Westport, CT: Greenwood, 1951), 376,377 . 
denominations ${ }^{1}$ and Jews taught religion in the public schools. Students who did not belong to these traditional churches were allowed to exchange their religion classes for ethics classes. ${ }^{2}$ Clergymen could procure higher religious education in local or foreign universities and seminaries. Even Seventh-day Adventists had in Riga province a Mission Seminary from 1924 to $1941 .^{3}$

It seems that religion was deeply rooted in Latvian pre-Soviet and pre-war society. Unfortunately, this period of prosperity and freedom ended with the Soviet invasion and World War II. At this time, churches suffered serious losses. "Many of the most religious individuals and clergy fled as refugees to the West or were deported to Siberia. A large number of church buildings were demolished by war action. ${ }^{, 4}$

\section{Second Half of the Twentieth Century}

During the second half of the twentieth century, religion in Latvia was under the pressure of atheism and communism. It was the intention of the Soviet government that "religious bodies shall wither away and die." Therefore, many churches were closed. Many church buildings were confiscated and either

${ }^{1}$ Lutheran, Catholic, Russian Orthodox, and Old Believers churches.

${ }^{2}$ Balodis, 131.

${ }^{3}$ E. Černevskis, Adventes Kustība Latvija (The Adventist Movement in Latvia) (Riga, Latvia: Patmos, 1998), 16, 17.

${ }^{4}$ Iwaskiw, 122.

${ }^{5}$ Trevor Beeson, Discretion and Valour (Glasgow: Collins, 1982), 150. 
demolished or given to political organizations. Only local executive committees could decide whether a congregation needed a church or not.

Schools usually fulfill the role of a potential influence in a society. For that reason "a sharp separation of schools from the church was advocated by the Communists."1 Consequently, to teach religion in schools was forbidden. Seminaries and the theological department of the Latvian University ceased to exist. Religious books were taken out of libraries and collected in special places, where people could not read them. Henceforth, not only the printing of books, but even of small religious song sheets, required special permission from the state. ${ }^{2}$

Legally, religion was separated from the state and declared to be a private matter for each individual citizen. During that time "there was no possibility to reach the unchurched or even non-churchgoing members outside of the portals of the churches." ${ }^{\text {"3 }}$ Public evangelistic work was non-existent. Because of atheistic misinformation, ${ }^{4}$ the general population viewed Christians as mentally sick, oldfashioned, or uneducated people. Partially this was true, because church attendance barred people from good education and job opportunities.

${ }^{1}$ Paul Mojzes, Church and State in Postwar Eastern Europe (Westport, CT: Greenwood, 1987), 16.

${ }^{2}$ Balodis, 142 .

${ }^{3}$ Kurt Hutten, Iron Curtain Christians (Minneapolis: Augsburg, 1967), 71.

${ }^{4}$ The facts of antireligious propaganda reveal matters on the surface only. For example, the "Evangelical Lutheran church in 1953 married 1086 couples and in 1969--only 134 couples." Balodis, 147. 
Fifty years of occupation, ideological indoctrination, and isolation caused spiritual and ethical damage to the whole Latvian society. The past atheistic propaganda also "produced a great number of people without any positive attitude to Christian faith and laid the ground for superstition and new religious movements."1

In the second half of the 1980s, during the Gorbachev era, the long-closed doors of religious freedom slowly began to open. Churches and religious groups who had worked underground received some freedom from the government. ${ }^{2}$ Some religious workers received the opportunity to go abroad for religious education. Foreign church leaders were allowed to come and visit their brothers and sisters in the country. At this time religiosity seemed to be re-awakening in people's hearts.

At the Threshold of the Millennium

During the last ten years of the twentieth century, religion in Latvia changed its face several times. People, tired of a communist ideology, at first sought to fill an inner void by becoming Christians and going to church. Almost all traditional churches ${ }^{3}$ doubled their membership, and many more new religious

\footnotetext{
'Tom Dorris, "Northern Europe," in Remembering the Future: The Challenge of the Churches in Europe, ed. Robert C. Lodwick (New York: Friendship, 1995), 29.

${ }^{2} J a r o s l a v$ Bilocerkowycz, "Latvia," A-to-Z Geography, $<$ http://school.discovery.com/homeworkhelp/worldbook/atozgeography/1/314760. html $>$ (accessed 25 October 2001).

${ }^{3}$ The following churches in Latvia are called traditional: Lutherans, Roman Catholics, Orthodox, Old Believers, Baptists, Jews, Seventh-day Adventists, and
} 
groups were organized. People were open to accept almost everything, even Eastern religions, and new religions flooded the country.

By the mid-1990s, the religious hunger of the nation began to decline. It seemed that people had found what they were looking for. Most believers continued to attend their own church services, but there were no large-scale numbers of new conversions. Religiosity in Latvia reached a plateau stage. By 1999 , a large percentage of the so-called believers no longer regularly practiced their faith. "It is reliably, if informally, estimated that only 2 percent of the population regularly attend church services, and that regular worshipers are predominantly women."1

Adapting to this trend, in 1996, the Parliament amended the Law on Religious Organizations. One of the amendments "reduced the number of persons necessary to seek registration as a religious organization from a minimum of 25 to 10 persons residing permanently in the country."2 Today, however, precise denomination membership statistics are not available. The Justice Ministry registered over 1,000 congregations with only estimates of church membership, which are the following: Lutherans $(400,000)$, Roman Catholics $(500,000)$, Orthodox $(190,000)$, Baptists $(6,000)$, Old Believers $(70,000)$, Seventh-day

Methodists. All of them, except Seventh-day Adventists and Methodists, are members of the Traditional Consultative Church Board. Balodis, 294, 295.

1،U.S. Department of State Annual Report on International Religious Freedom for 1999: Latvia," <http://www.state.gov/www/global/human rights/irf/irf rpt/1999/irf latvia99. html $>$ (accessed 16 October 2001).

${ }^{2}$ Tbid. 
Adventists (4,000), Jehovah's Witnesses (2,000), Methodists (500), Jews $(6,000)$, Buddhists (100), Muslims (300), Hare Krishna (500), and Mormons (200). ${ }^{1}$ There are also still a significant number of atheists, perhaps half of the population.

Recently in Latvia, an old non-Christian Latvian religion, called Dievturiba, has been spreading rapidly. The exact number of its followers is not known. At the foundation of Dievturiba lies an understanding of God, which was developed, improved, and preserved in national folk songs by Latvian ancestors. In Dievturiba the highest spiritual concept is the only God. It cannot be called even a faith in general meaning, because it does not emphasize believing but has only a realization about God. In practice Dievturiba manifests itself in cultic rituals, which consist of frequently mentioning God's name, praying, sacrificing, drawing symbols of God, etc. The main laws of this religion are goodness, honor, morality, and obedience. By its essence, Dievturiba is thoroughly pagan; it worships nature, ${ }^{2}$ and believes in immortality that expresses itself in the form of visual images of memory. ${ }^{3}$

With so wide a variety of religions in so small a country as Latvia, its government tries to support the principles of religious freedom. However, "there are ongoing confidential negotiations between the Government and the Vatican

\section{${ }^{1}$ Ibid.}

${ }^{2}$ In order to introduce the gospel message to every person, Adventists look for a common ground. In a case of Dievturiba, a common ground could be presented in a form of incentives for obedience, value of morality, and nature. The last one is as an important tool for reaching these people with the health message.

${ }^{3}$ Balodis, 333-336. 
concerning a new Concordat.... The new Concordat reportedly would grant the Roman Catholic Church a privileged status."

In regard to religious instruction in public schools today, only the denominations represented by the Traditional Consultative Church Board have the opportunity to teach children; and only these denominations can establish religious instruction institutions of higher education such as seminaries. ${ }^{2}$ Lutherans and Roman Catholics already have their own seminaries. At the same time, every person is eligible to study in the University of Latvia's theological faculty, which is nondenominational.

This brief description of Latvian society, culture, and religion with the latest developments concerning them presents a rather mixed picture. It is rather hard to foresee what direction of these developments may take in the future. Whether these trends will be positive or negative, they will vitally affect the proclamation of the gospel in Latvia.

1"U.S. Department of State Annual Report on International Religious Freedom for 1999: Latvia," Internet.

${ }^{2}$ Ibid. 


\section{CHAPTER 3}

\section{SEVENTH-DAY ADVENTIST EVANGELISM IN LATVIA}

The history of the Adventist church in Latvia can be divided into several periods: from its beginning to World War II (1895-1940), the Soviet era (in Latvia, 1940-1990), and restored freedom for evangelism during the final decade of the twentieth century. During these time periods political, economical, and social changes affected both positively and negatively the progress and methods of evangelism.

\section{Evangelism before World War II}

General Background of Adventist Church

The Seventh-day Adventist message came to Latvia for the first time in 1895, when Johans Perks, a literature evangelist, moved from Russia to Riga, the capital city of Latvia. During one year of his work he was able to organize the first Adventist Church in the country with twelve members. ${ }^{1}$

These new church members boldly shared the gospel with others. The Word of God was introduced to many people in different Latvian towns. By 1914,

\footnotetext{
${ }^{1}$ Černevsskis, 6.
} 
eleven churches were already organized. ${ }^{1}$ It seems that some of the main ways of spreading the Gospel were preaching and practically living out the Word, and also doing literature evangelism.

By the middle of the 1920s Adventists in Latvia gained acceptance in the society and the privilege to freely keep the Sabbath day at schools and in the military service. At this time the church experienced tremendous growth in numbers. In 1921 the total membership was 1,244. By the beginning of 1929 church membership had increased by 914 members, and in the 1934 the church had 2,950 members. ${ }^{2}$ See fig. 5.

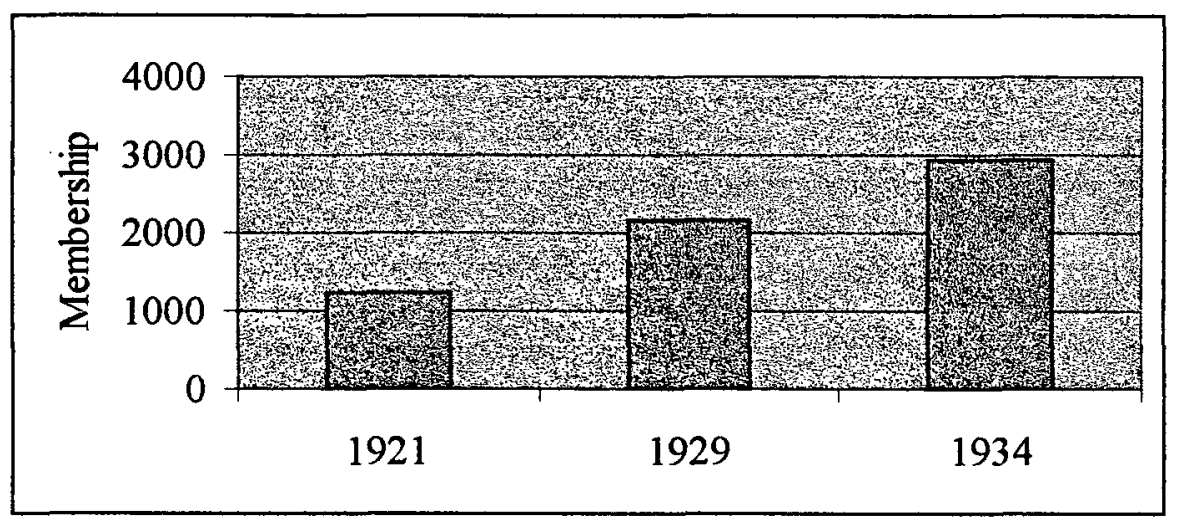

Fig. 5. Church membership of Latvian Conference $(1921,1929,1934)$.

During the next two years the Adventist church went through an unexpected downturn in the number of members. This decline was due to the new government law, issued in December of 1934, which announced that in order to
'Ibid., 8.
${ }^{2}$ Ibid., 19, 22. 
register a group of believers as an official church, it must have no less than fifty people. ${ }^{1}$ As a result of this new situation, small churches were disbanded and their members were attached to other nearby Adventist churches.

In spite of that obstacle, Adventists continued to spread the gospel by all available means. The Lord blessed the faithful ones and the church continued to grow. Fig. 6 presents an overview of the church membership.

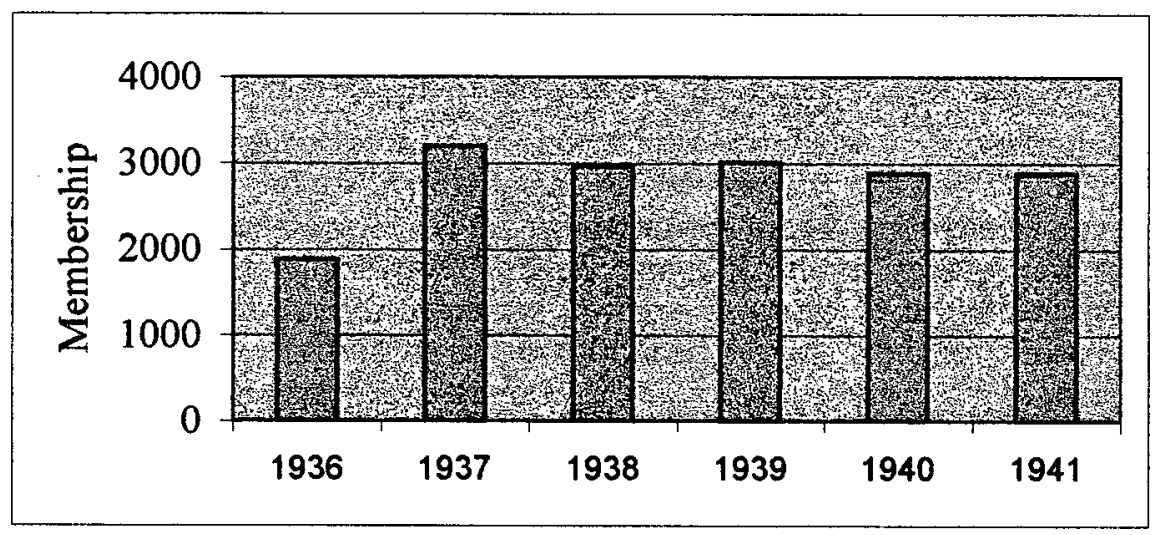

Fig. 6. Year-ending church membership of the Latvian Conference (19361941). From "Yearly Growth Analysis: Latvian Conference (1936-1998)," $\leq$ http:/statistics.gc.Adventist.org/ast/stats> (accessed 20 January 2002).

The years before World War II for the Latvian Seventh-day Adventist church were most rewarding. In spite of all the hardships, the Adventist message was reaching the inhabitants of far and nearby towns, villages, and farms, and new converts were the most influential witnesses about the transforming power of the Word of God. The church grew not only in numbers, but also in the spirit of ministry and mission. Both young and old were on fire to spread the gospel in

\footnotetext{
${ }^{1}$ Ibid., 22, 23.
} 
every corner of the country. That is why the Lord blessed His church with the seminary, a publishing house, and with faithful and fearless evangelists.

\section{Suži Mission Seminary}

One of the basic institutions for preparing missionaries, evangelists, pastors, and literature evangelists was Suži Mission Seminary, established in 1923. Even though the seminary existed for only seventeen years, it made a tremendous contribution to Adventist church expansion in Latvia and neighboring countries. ${ }^{1}$ During the first ten years, 106 students finished the Seminary and 50 of them decided to devote their lives to mission work. ${ }^{2}$

It is important to point out some details concerning the beginnings and the establishment of the seminary. During the first Latvian Seventh-day Adventist congress in 1920, youth of the church requested the delegates to vote for an organization of some spiritual classes that would help prepare them for missionary work. However, due to various obstacles, this request was not granted.

One year later it was decided to raise money for the building of an Adventist sanitarium. All Latvian Adventist churches took an active part in that project. They understood that having a sanitarium could help to unlock new opportunities and introduce new ways of evangelizing the country. At the same time, the youth continued to pray for the establishment of a missionary school or at

${ }^{1}$ By 1938,45 students from Estonia graduated from the Seminary (R. Vinglass, "Atminas par Seminãru Latvijā" (Memories About the Seminary in Latvia), Adventes Vêstnesis (Adventist Herald) 7 [1938]: 163).

${ }^{2}$ Ibid., 17. 
least some classes. Now these prayers and requests were heard and at the congress in May 1923 it was decided to transfer the whole sanitarium fund of Ls 5,000 to the school fund and to buy the property for the future missionary seminary at Suži. ${ }^{1}$

Since the early years of the existence of the Adventist church in Latvia, the church had felt a need for medical evangelism. However, it seems that the time had not yet come for building a sanitarium. It became obvious that there was a much more urgent need of having a missionary school, which after its establishment served as a lighthouse for all three Baltic Republics.

\section{Literature}

As early as 1905, the church's publishing house started to print the small booklet by Ellen G. White called Steps to Christ. During the period between World War I and World War II, various books of E. G. White and other Adventist authors were translated from English, German, and other languages into Latvian and Russian and then published.

Monthly periodicals also played an important role in spreading the good news of Jesus Christ. Of the three magazines in circulation, ${ }^{2}$ one was designed

'J. Oltinš, "Latvijas Adventes Misijas Seminārs" (Latvian Adventist Mission Seminary), Adventes Vēstnesis 7 (1938): 156.

${ }^{2}$ Adventes Vēstnesis was intended for the church members and Ciänas Sargs (Zion's Watchman) for those who were seeking the truth. In 1929 Ciānas Sargs was renamed as Müsu Laikmets (Our Age). The third publication for the youth was called Adventes Jaunatnes Vadonis (Adventist Youth Guide) (Černevskis, 21). 
especially to encourage young people to become Christian missionaries and literature evangelists.

Once a year the Conference published a beautifully illustrated Plaujas Numurs (Harvest Issue). The church members distributed it for freewill offerings in order to secure funds for their mission work. Also published on a regular basis were an Adventist Calendar, Morning Devotions, and Sabbath School Lessons for adults and children as well as annual Readings for the Week of Prayer.

\section{Colporteurs}

One of the most productive aspects of evangelism before World War II was the work of colporteurs or literature evangelists. One can only admire the perseverance, courage, and faithfulness of those young and old people. Whether in rain or snow, literature evangelists were going from home to home, bringing the Word of God even to the most distant farms. ${ }^{1}$ Because this kind of work was one of the most important aspects of evangelism, ${ }^{2}$ it is obvious why it was strongly emphasized in Suži seminary. As Černevskis points out, the rapid growth of the Adventist church in Latvia could take place largely because of the extremely

${ }^{1}$ Literature evangelists daily traveled from 8 to $20 \mathrm{~km}$ or in some cases even more, trying to reach isolated country farms with God's message (B. Baumans, "Draudžu Dzīve: Baldone" (Church Life: Baldone), Adventes Vèstnesis 4 [1926]: 44).

${ }^{2}$ Ellen G. White, Reflecting Christ (Hagerstown, MD: Review and Herald, 1985), 253. 
active and aggressive work of colporteurs, who "tried not to pass even one apartment or one farm."

For example, due to the work of colporteurs, the Ādaži Adventist church, one of the youngest churches in the Conference in 1926, baptized nine persons on one Sabbath and on the following Sabbath two more. ${ }^{2}$ However, this work was not restricted only to Latvia. Literature evangelists from Suži seminary worked also in the neighboring countries of Estonia and Lithuania.

\section{Bible Groups}

Hundreds of young people consecrated themselves to Christ. Their hearts were burning with the desire to do a missionary work by using any available opportunity. In order to reach their goals they started Bible Group activities. For example, one such activity was carried out not far from Riga, in Jaunciems, with a population of about 1,000 people. The youth made and distributed 500 invitations. Almost all of the invited people came to the Bible Group meeting in the local cinema. Unfortunately, because of the lack of space many visitors had to return home. At that meeting the biblical message was followed by songs. The attending people had open hearts and a real interest in the message. The sincerity and earnestness of their intentions could be seen in a positive response concerning their rich donations of free-will offerings and the records of the sold literature. ${ }^{3}$

${ }^{1}$ Černevevskis, 19.

${ }^{2}$ A. Juris, “Draudžu Dzīve: Ādaži,” Adventes Vētnesis 6 (1926): 63.

${ }^{3}$ A. Jurkevics, "No Misijas Skolas," Adventes Vēstnesis 2 (1927): 12, 13. 


\section{Evangelistic Meetings}

Young people played an active role in helping to prepare and conduct large evangelistic meetings. For instance, in November 1923, Kārlis Roze presented the biblical truth in Latvian and German languages in Liepāja. He rented a hall that seated 600 . The auditorium was crowded every night. Roze had a unique opportunity to acquaint the people with the basic biblical teachings. All together he held 50 meetings. Soon 26 people were baptized with many more later. ${ }^{1}$ Such seminars were held in many parts of the country. They brought people to God and acquainted them with the Word of God.

In spite of the fact that there were many obstacles and hardships, God's work continued to progress in His church in Latvia because evangelizing Adventists had committed themselves "to equipping people to live as disciples of Christ and citizens of the kingdom of God."2 Unfortunately, the privileges for evangelism did not long continue. In 1940, Latvia was occupied by the Soviet Army. A year later, World War II came to Latvia and the church almost ceased to function as an organized unit.

\section{The Church during the Soviet Era}

It is almost impossible to present any information about evangelism in Latvia during the Soviet era. The Seventh-day Adventist church, like other

'Kārlis Roze, "Pirmā Pusgada Darbs un Panākumi Liepājā" (The Work and Success in Liepaja during the First Half Year), Adventes Véstnesis 5 (1924): 54, 55.

${ }^{2}$ Kenneth Eriks, Reach Out \& Receive (New York: Reformed Church, 1988), 5. 
churches in the country, was denied any opportunity of spreading the gospel. Even more, some Adventist pastors were taken to prisons or sent to Siberia. Almost all church properties and church buildings were taken away, and it was forbidden to print or distribute any religious literature. ${ }^{1}$

Consequently, the church suffered tremendous loss. It is difficult to determine even the approximate number of church members during those years because official documents, for reasons of secrecy, were not kept. Unofficial estimates indicate that the church membership in Latvia in 1960 was about $2,600{ }^{2}$ In fact, during the years of the communist regime the church membership declined even more.

At the same time the church stood firmly in doctrines and teachings. ${ }^{3}$ In spite of the hardships, small baptisms were carried out in every church. Sometimes the names of new church members cannot be found in the church books, but they were accurately kept in the minds of the church members and in the heavenly books. The mission work was continued and carried out mostly among the children of the church members ${ }^{4}$ and sometimes close friends.

\footnotetext{
${ }^{1}$ Mojzes, 20, 21.

${ }^{2}$ Černevskis, 45.

${ }^{3}$ Ibid.

${ }^{4}$ Alf Lohne, Adventists in Russia (Hagerstown, MD: Review and Herald,
} 1987), 129. 
After the mid-1970s, the Soviet government's greater tolerance for religion resulted in what Paul Steeves called 'normalization of conditions for believers.' These new conditions allowed the Adventist church in Latvia together with other churches in the state to express their religious concerns and objectives.

Even though the Latvian Conference as an organization finished its existence in $1949^{2}$ and until 1989 there was no official Seventh-day Adventist Conference in Latvia, the church was led by God Himself through His faithful pastors. The first step toward the restoration of the Latvian Conference was taken in 1979 when the church elected Jānis Oltinš as the elder of the Latvian church. The second step came three years later when the first Latvian committee was elected with four pastors on it. It was an important turn after so many years of being under repression. The third and last step toward the organization was made in $1989 .{ }^{3}$ Almost half a century had passed and now the Latvian church could send her delegates to the Conference congress, which opened a new page in the history of the Adventist church in Latvia. From this time on, the spirit of evangelism started to awaken and recover from the long period of severe antagonistic repression by communism.

Even though public evangelism was still not allowed, church members were eager to spread the gospel to their relatives, co-workers, neighbors, and 124.

'Paul D. Steeves, Keeping the Faiths (New York: Holmes \& Meier, 1989),

${ }^{2}$ Černevskis, 30 .

${ }^{3}$ Ibid., 46. 
friends. The 1980s were not marked with many baptisms, but it was a period of preparation for the harvest that would occur during the following decade. Some churches became smaller in membership because of the revisions done in the church books, and some of them grew larger. See fig. 7 .

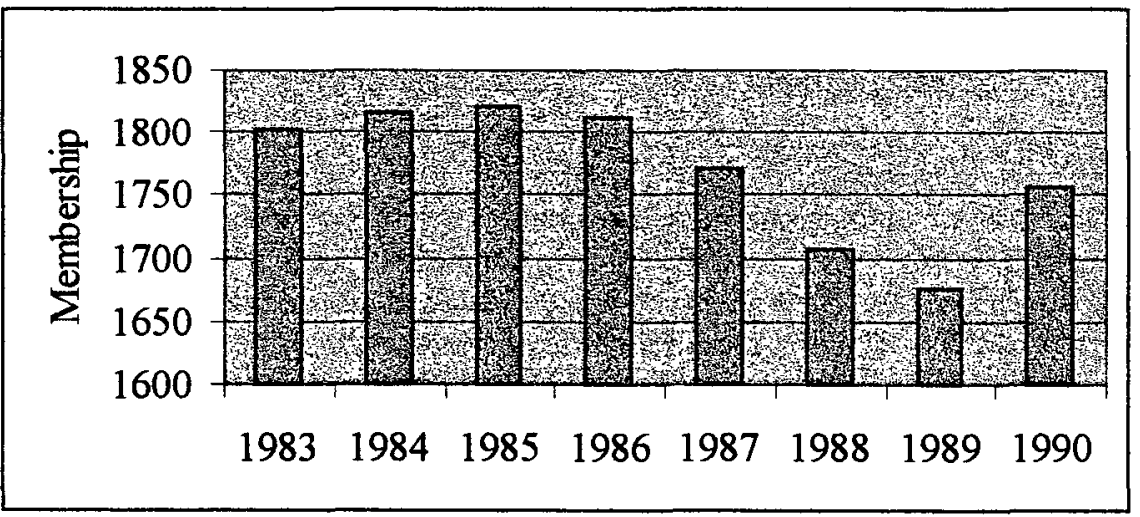

Fig. 7. Year-ending church membership of the Latvian Conference (19831990). From "Yearly Growth Analysis: Latvian Conference (1936-1998)."

As the night seems darkest just before dawn, so it was with the church membership in Latvia. It is difficult to tell the accurate reasons of the decline; one prominent factor, however, among many that could be mentioned, was the consequences of the political administration during the previous years. ${ }^{1}$

${ }^{1}$ According to Barna, a church decline is affected by eight symptoms: demographic changes, inadequate leadership, poor management, old blood, building campaigns, the ingrown family, resistance to change, and spiritual health (George Barna, Turn-Around Churches [Ventura, CA: Regal Books, 1993], 3238). 


\section{Restored Freedom for Evangelism}

The third period of Adventist church history in Latvia began with the last ten years of the twentieth century. When communism unraveled in Latvia, the Adventist church emerged from its dormant state. At this time the Lord opened the doors of new opportunities to evangelize the country. Public evangelism, Bible classes, prison ministry, literature evangelism, radio broadcasting, and other types of evangelism were the most effective means of church growth.

\section{Public Evangelism}

In summer of 1991, Jack Colon ${ }^{1}$ arrived in Riga as a foreign evangelist to hold the first public evangelistic meetings in Latvia, thus introducing a new era of the proclamation of the gospel in the country. Those few older pastors who survived persecutions and hardships and who used to lead evangelistic campaigns during the years of Latvian independence were now too old to do the work; and the new generation of pastors had no idea how to lead such campaigns. Therefore, guest-evangelists such as Jack Colon, Kenneth Mittleider, ${ }^{2}$ David Currie, ${ }^{3}$ and many others not only carried out evangelistic campaigns, but also taught the local pastors the basic strategies and techniques of how to lead their local churches in

${ }^{1} \mathrm{~J}$. Colon is the church evangelist and in 1991 he was also the director of the Seventh-day Adventist North-West Evangelism Institute of America.

${ }^{2}$ At that time Kenneth Mittleider was the vice president of the General Conference of the Seventh-day Adventist church. During his campaign in Riga in 1992, 367 persons were baptized.

${ }^{3}$ David Currie was the ministerial secretary of the Trans-European Division. In 1995, he carried out two evangelistic campaigns in Riga, where more than 200 people were baptized ("Riga Meetings Draw Record Crowds," Messenger, 31 March 1995, 2). 
public evangelism. They strongly emphasized that the most important work of the church is outreach or soul-winning ministry. The clear implication of this emphasis points to the fact that the primary evangelists are the church members themselves, ${ }^{1}$ and that pastors are to equip the members under their charge for this vital task. $^{2}$

The first part of the 1990s in Latvia can be characterized as a period of explosion and rebirth of evangelistic campaigns all around the country. In those days evangelistically minded Adventists found ways and means for communicating the good news to the masses of contemporary people in three languages--Latvian, Russian, and sign language. ${ }^{3}$ As a result, the general population started to "look at Christianity as the only hope for the spiritual restoration.... They had lost all confidence in the advocates of Marxism and atheism."

'Werner Vyhmeister, "What Can Laypersons Do in Ministry?' in Adventist Mission in the $21^{\text {st }}$ Century, ed. John L. Dybdahl (Hagerstown, MD: Review and Herald, 1999), 170.

${ }^{2}$ Melvin J. Steinbron, Can the Pastor Do It Alone? (Ventura, CA: Regal Books, 1987), 93.

${ }^{3}$ In 1992, after a large evangelistic campaign in Rīga, 62 deaf persons were baptized. Since that time the ministry to the deaf is an ongoing evangelism. "The deaf people are interested in making changes. The Adventist message is very attractive to deaf people because it is a wholistic message. It is concerned with the spiritual, mental, social, and physical aspects of man" (Rikki Stenbakken, "Deaf Services Reach Out to World Church," Outlook [Mid-America Union], June 1994, 29). 15.

${ }^{4}$ Mikhail Kulakov, God's Soviet Miracles (Boise, ID: Pacific Press, 1993), 
The second half of that period may be characterized as the period of various local evangelistic campaigns done in different parts of the country. The success of these meetings was not as great as it had been in the previous years. Economic recession, unemployment, and other factors led people to apathy and loss of interest in religion. Consequently, these negative influences and apathetic attitudes left their impact on public evangelism as well.

\section{Bible Classes}

Bible classes represented another approach of evangelizing the country. During the first part of the decade, local church members together with their pastors were actively looking for new ways of acquainting people with the Word of God. They started various outreach programs and moved in all possible directions, watching where and how the Lord would open doors of opportunity. It seemed unbelievable, but for a short time many lay members had the opportunity to teach the Bible not only in public schools, but also in public libraries and recreation halls. People were hungry for the spiritual truth and they accepted it with an open heart and mind. One day per week, usually on Sundays when people were free from work, young and old came together to find out what the Bible says about such vitally important issues as personal salvation, prophecies, the second coming of Christ, etc.

Bible class evangelism did not give such obvious results for church growth as did public evangelism, but many people were baptized and the classes provided a unique opportunity and privilege to bear witness about Jesus' love and His willingness to save the lost. People received the true message from the Bible 
and they personally became acquainted with Adventists. Unfortunately, this type of evangelism worked only for a short period of time. As mentioned in the previous chapter, Adventists in Latvia are no longer permitted to teach Bible in the public schools. ${ }^{1}$

\section{Prison Ministry}

Around 1993, another door of opportunity was opened for spreading the gospel--in Latvian prisons. The Lord had prepared men and women to devote their lives to exactly this type of ministry. Thanks to this ministry, more than one hundred people were baptized in Latvian prisons with many more still on their way to making a decision for Christ. ${ }^{2}$ This prison ministry also involves rendering help to the inmates' relatives, especially their children. The center of charity, Jaunā Dzive (New Life), was established with the goal of practically assisting those who live in miserable circumstances and are struggling financially on a daily basis. ${ }^{3}$ Today this organization continues its work by helping orphanages and those people who come out of prisons and have difficulties with rehabilitation. ${ }^{4}$

"'Latvia," Record (South Pacific Division), 16 May 1998, 10.

${ }^{2}$ In 1996, 56 persons were baptized in one of Riga's prisons ("A Captive Audience," Record, 26 October 1996, 4).

"'Labdarỉbas Centra 'Jaunā Dzive' Atskaite" (The Report of the Center of Charity 'New Life') Adventes Vēstis (Adventist Message), February 1999, 7.

${ }^{4}$ Rita Kaulina, "Cenšas Palīdzēt Bāreņiem un Bijušajem Ieslodzītajiem" (Strive to Help the Orphans and Previous Inmates), Adventes Vēstis, May 2001, 2. 


\section{Literature Evangelism}

Literature evangelism played one of the most important roles in spreading the gospel in the country in 1920s and 30s and became one of the major ways of evangelizing Latvia in the 1990s. After Latvia became independent, the church regained its previous freedom to print books, magazines, and other Adventist literature. Talented young people started to work on translating books, mostly from English. They tried to use every opportunity at the state's publishing houses in order to print religious literature in the Latvian language. At the same time, supplies of literature in the Russian language have been sent mainly from Zaoksky and Kaliningrad, Russia.

At the beginning of the 1990s, when people were more hungry for spiritual truth, the doors of homes and apartments were open for the gospel and people were eager to buy Bibles and Adventist books. ${ }^{1}$ Literature evangelists with bags full of books, Bibles, and magazines in both languages started to cross the country in all directions. This type of evangelism still continues to work and people buy books in spite of their financial difficulties. ${ }^{2}$ Some literature evangelists even managed to open several Adventist book kiosks and sell religious literature in the very center of Riga, the capital city.

${ }^{1}$ Kulakov, 14.

${ }^{2}$ A. Bite, "Savāda Sastapšanās" (A Strange Encounter), Adventes Vēstis, February 1999, 8. 


\section{Radio Broadcasting}

Since the mid-1990s "the church in Latvia has leaped over several generations of audio studio techniques to embrace computer editing, $\mathrm{CD}$ players and DAT (Digital Audio Tape) recorders."' A new radio studio was opened in Riga to serve the Latvian population by proclaiming the gospel.

Before the dedication of the studio in December 1995, Latvian Adventists had already worked for some time with the state Christian radio station, but without any training. Therefore, Adventist World Radio provided basic training programs and funding. ${ }^{2}$ Today the Latvian Adventist radio studio works to reach every person in the country with the Three Angels' message in the Latvian and Russian languages. Even though the message is still broadcast through the Christian radio station, new technology has given an advanced step in evangelizing the country. ${ }^{3}$

\section{Opportunities for Pastors' Education}

In order to be better prepared to reach people with the everlasting gospel in a politically and economically fast-changing world, pastors should be trained to

\footnotetext{
I'Leading Edge Technology Powers Latvian Studio," The Atlantic Union Gleaner, March 1996, 4.

${ }^{2}$ Ibid.

${ }^{3}$ Aidis Tomsons, "Rādio Darbs" (Radio Work), Adventes Vēstis, March 2001, 2, 3. Also T. Tomsone, "Komunikācijas Nodala" (The Department of Communication), Adventes Vēstis, October 2000, 7.
} 
use different and more useful approaches and methods of presenting Christ. ${ }^{1}$ Sadly, for almost fifty years Latvian pastors have not had this opportunity; but with the return of freedom from communism, the Lord opened the doors of opportunities for pastoral education.

During the last decade of the twentieth century some of the young pastors had the privilege of studying at Zaoksky Theological Seminary in Russia, and others were even able to go to Newbold College in England, Spicer College in India, Andrews University in the USA, etc. Unfortunately not all the pastors were so privileged. Only a few were able to leave the country and get a theological education abroad.

The majority of the pastors, however, were not able to enroll in any educational institution because of their continued active service in their churches. In order to help them become more deeply rooted in the basics of biblical theology and practical ministry, the Baltic Union Conference together with the help of Trans-European Division started to organize extension courses and also summer classes. $^{2}$

'Ellen G. White, Testimonies for the Church (Mountain View, CA: Pacific Press, 1948), 9:32; idem, Counsels to Parents, Teachers, and Students (Mountain View, CA: Pacific Press, 1943), 11, 12.

2“Newbold Goes Off-Campus," Record, 18 April 1998, 5. Regarding Adventist Suži seminary, the Latvian Conference with the Baltic Union is still continuing to work on the project of regaining this property, which was used for 50 years by the Soviets and later Latvians as a military base, or being reimbursed with other property of equal value (A. Tomsons, "Par Draudzes İpašumiem" [About Church's Property], Adventes Vēstis, November 2000, 2). 


\section{Growth in Numbers}

In the 1990s the Adventist church in Latvia almost doubled its membership. The years 1991 to 1995 were especially years of rapid growth. All of the above-mentioned evangelistic opportunities with many other varieties of evangelism echoed in the numbers of church members. Fig. 8 reveals this increase in church membership. In 1991, there were 2,114 members and in 1995, this number grew to 3,789 members.

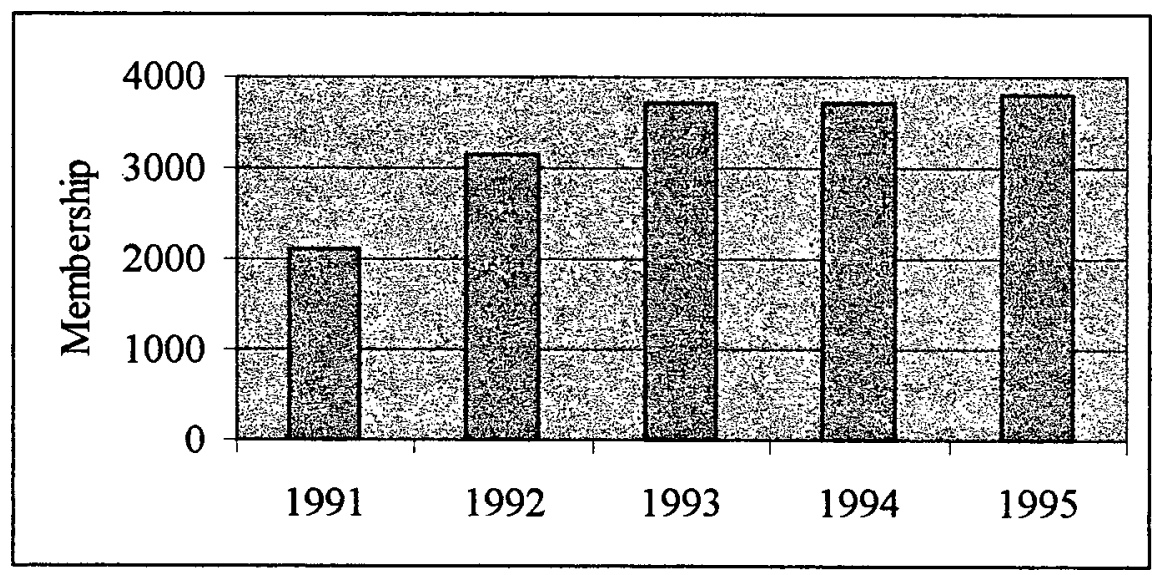

Fig. 8. Year-ending church membership of the Latvian Conference (19911995). From "Yearly Growth Analysis: Latvian Conference (1936-1998)."

The second part of the 1990 s may be characterized as a plateau stage with a slight decline. Even though the church has worked hard, the results have not been impressive. Fig. 9 shows the data of the church membership from 1996 to 2001. 


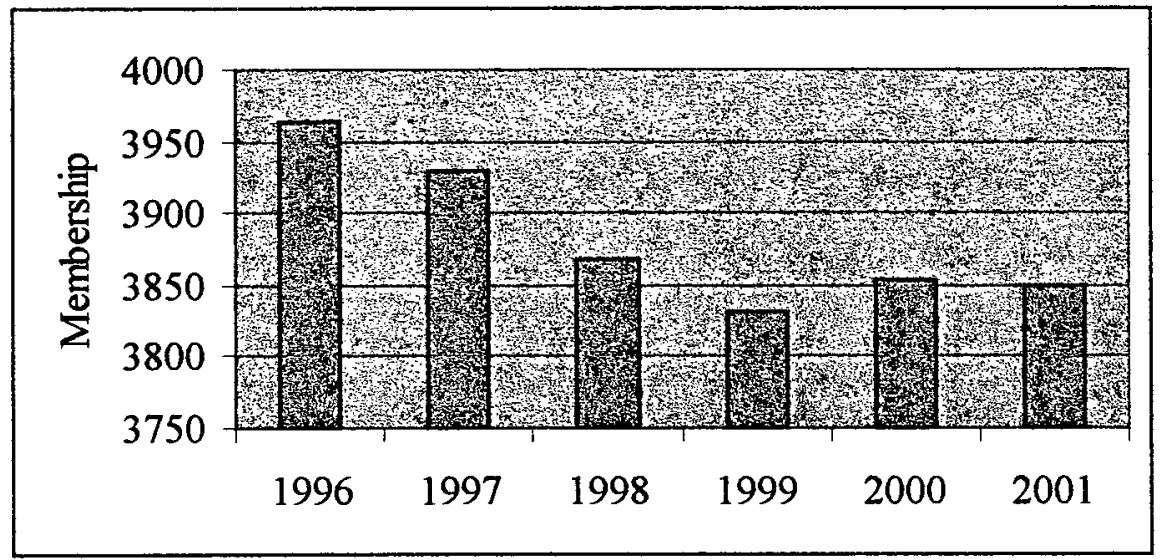

Fig. 9. Year-ending church membership of the Latvian Conference (1996-2001). From "Yearly Growth Analysis: Latvian Conference (1936-1998)" and the latest statistics received from the Latvian Conference through e-mail.

The problems causing a church to decline are no respecters of boundaries. They may relate to people, culture, facilities, theology, geographical location, and finances about which the previous chapter speaks. Decline may also be caused by inappropriate programs and style of ministry.

This chapter attempted to take into consideration the complicated background and the whole current picture of political, economical, national, and social aspects and trends in the life of the Latvian population, in relation to all the above-mentioned types of evangelism. It appears that the time has come for the Adventist church in Latvia to be actively involved in initiating new varieties of evangelism, one of which could be medical evangelism or wholistic health ministry. ${ }^{1}$ According to those who have used it in other countries, this type of evangelism will meet the needs and "particular interests of the community that is

\footnotetext{
l"Evangelism was not to be done separate from the health message. That's why many evangelists ... make health a part of their public presentations" (Williams, Kuzma, and Van Dolson, 59).
} 
targeted,"1 acquaint them with the gospel message, and consequently lead to church growth.

'Earl P. W. Cameron, Evangelism in Today's World (Oshawa, Ontario: Maracle Press, 1996), 91. 
CHAPTER 4

\section{A BIBLICAL FOUNDATION FOR WHOLISTIC HEALTH MINISTRY}

It is not immediately evident whether the Bible contains any information regarding the wholistic health approach and ministry that could serve as the biblical foundation for SDA health evangelism in Latvia. This chapter investigates selected biblical passages, which relate to many-faceted healthful lifestyle issues.

The first part of the chapter acquaints the reader with God's original plan for a healthful lifestyle. The second part deals with sickness and healing issues in the Old Testament (OT) period and speaks about the greatest Physician. The third part focuses on Jesus' teachings and healing ministry. It also discusses the mission of His disciples, later called apostles.

\section{God's Original Plan}

"And the Lord planted a garden in the Eden, in East; and there he put the man whom he had formed" (Gen 2:8). As the crown of all creation God created Adam and Eve-the first human beings. He gave them the Garden of Eden to be 
their home, ${ }^{1}$ the place where they would live, work, rest, and worship their Creator. $^{2}$

Every step in creation was designed to provide for people the essentials of life and happiness. "God saw everything that he had made and indeed, it was very good" (Gen 1:31). ${ }^{3}$ Before their fall the first couple were healthy mentally, spiritually, and physically. They did not have even the slightest disease. The basic conditions for good health include at least eight factors: fresh air, sunlight, pure water, exercise, proper diet, periodic rest, temperance, and trust in God. ${ }^{4}$ All of these are clearly evident in the opening two chapters of Genesis.

\section{Fresh Air}

On the second day of creation, God created the atmosphere. He knew how necessary it would be for all His future creation. So when on the sixth day the Lord created man, He "breathed into his nostrils the breath of life; and the man

${ }^{16}$ 'It is simpler to associate Eden with its homonym 'pleasure, delight' (2 Sam 1:24; Jer 51:34; Ps 36:9). Whenever Eden is mentioned in Scripture it is pictured as a fertile area, a well-watered oasis with large trees growing (Isa 51:3; Ezek $31: 9,16,18$ ), a very attractive prospect in the arid East" (Gordon J. Wenham, Genesis 1-15, Word Biblical Commentary [Waco, TX: Word Books, 1987], 1:61).

${ }^{2}$ John H. Sailhamer, The Pentateuch as Narrative (Grand Rapids: Zondervan, 1992), 100.

3"God saw EVERYTHING that He had made, the creation in its totality, and He perceived that not only were the details, taken separately, good, but that each one harmonized with the rest; hence the whole was not just good, but very good" (U. Cassuto, From Adam to Noah, A Commentary on the Book of Genesis [Jerusalem: Magnes, 1998], 1:59).

${ }^{4}$ Ellen G. White called these eight principles of health "the true remedies" (Ministry of Healing, 127). Today they are found under various acronyms, such as NEWSTART (Nutrition [proper], Exercise, Water, Sunlight, Temperance, Air, Rest, and Trust), FRESH START, STEWARDS, etc. 
became a living being" (Gen 2:7). ${ }^{1}$ From that moment Adam's lungs began to function together with the other parts of his body. ${ }^{2}$ He breathed the kind of fresh air that no place on earth can boast today. Human life is completely dependent on breathing in adequate oxygen and breathing out carbon dioxide. Fresh air is "the elixir of life." 3 Therefore, God bestowed on Adam and Eve the privilege of associating with Him in the fresh air of the Garden of Eden.

\section{Sunlight}

Fresh air was good, but it was not enough to sustain life on earth. So on the fourth day God created the sun and moon (Gen 1:16) for the future of His earthly children. These lights were "subject to his purposeful will.", They were made to regulate and influence agriculture and other aspects of life. The sun's heat and radiation were given as great blessings to life when used as directed by the Creator. Adam and Eve were especially thankful to God for the benefits of sunshine. Though God Himself sustained them, they still needed sunlight, for it

\footnotetext{
${ }^{1}$ The man "is the recipient of the divine breath. ... Until God breathes unto him, man is lifeless corpse" (Victor P. Hamilton, The Book of Genesis, Chapters 1-17, The New International Commentary on the Old Testament [Grand Rapids: Eerdmans, 1990], 159).

2،After fashioning the inanimate figure, God enabled it to breathe the aira clear indication of life - and thereby the lifeless body became a living soul, a living being" (Cassuto, 106).

${ }^{3}$ White, Testimonies for the Church, 7:76. A person can exist without food for a few weeks, endure without water for a few days, but can survive for only a few minutes without breathing.

${ }^{4}$ Kenneth A. Mathews, Genesis 1-11:26, New American Commentary (Nashville: Broadman \& Holman, 1996), 154.
} 
builds up the immune system, and synthesizes and builds vitamin $D$ in the skin. ${ }^{1}$

There are many other benefits of sunlight, which people still enjoy today, so many centuries later. ${ }^{2}$ Sunshine is a disinfectant and a killer of bacteria. "It invigorates the body and cheers up the spirit."

\section{Pure Water}

Pure water was another gift from God to the new couple. "A river flows out of Eden to water the garden" (Gen 2:10). The availability of water in liquid form is one of the basic conditions for life on earth. The Creator made human beings not only from the dust of the ground (Gen 2:7), but also from water. The human body consists of approximately 70 percent water, all of it essential for the proper function of the body, from the minutest cell to the most important organ. ${ }^{5}$ God knew that human beings could survive longer without food than without water, so He provided Adam and Eve with fresh water to drink, to sustain their bodies. At the same time, a river of water is symbolic of the life-giving presence

${ }^{1}$ Reuben A. Hubbard and Don Hawley, Health Secrets of the Bible, Abundant Living Health Series (Loma Linda, CA: Loma Linda University, 1984), 6.

${ }^{2}$ Gunther B. Paulien, The Divine Prescription and Science of Health and Healing (Brushton, NY: TEACH Services, 1997), 102-107.

${ }^{3}$ Philip G. Samaan, Christ's Way to Spiritual Growth (Hagerstown, MD: Review and Herald, 1995), 185.

${ }^{4}$ Ellen G. White, Sons and Daughters of God (Washington, DC: Review and Herald, 1955), 241.

${ }^{5}$ Samaan, 182. 
of God. ${ }^{1}$ Ellen G. White wrote: "In health and in sickness, pure water is one of heaven's choicest blessings."2

\section{Exercise}

"The Lord God took the man and put him in the Garden of Eden to till it and keep it" (Gen 2:15). Even before the fall, man was expected to work; ${ }^{3}$ paradise was not a life of "uninterrupted bliss"4 or leisured unemployment. Therefore, God endowed Adam and Eve with energy to move, work, and become fit and strong. He knew that inactivity invites disease, but exercise promotes health, and only physically active people find the true joy of life. Diehl and Ludington attest that a "sedentary lifestyle is the quickest route to an early death. Inactivity kills us-literally." ${ }^{5}$ On the other hand, "greater vitality, better health, and longer life can be ours through regular, brisk physical activity." God wanted to see not only His first human couple but also their descendants strong and

${ }^{1}$ Wenham, 65.

${ }^{2}$ White, Ministry of Healing, 237.

3."Physical labor is not a consequence of sin. Work enters the picture before sin does, and if man had never sinned he still would be working" (Hamilton, 171).

${ }^{4}$ Ibid.

${ }^{5}$ Hans Diehl and Aileen Ludington, Lifestyle Capsules (Santa Barbara, CA: Woodbridge, 1991), 164.

${ }^{6}$ Ibid. 
healthy, because a "man who would refuse to exercise his limbs would soon lose all power to use them."1

\section{Proper Diet}

The Lord designed the human body "fearfully and wonderfully" (Ps 139:14) in every way. And when it came to nourishing the first people, $\mathrm{He}$ provided them with the right food for maintaining optimum health. "See, I have given you every plant yielding seed that is upon the face of all the earth, and every tree with seed in its fruit; you shall have them for food" (Gen 1:29). This passage seeks to convey that the human diet should come from plants and that meat was not part of such a diet. ${ }^{2}$ It presents here an idealized picture of the primeval world situation. ${ }^{3}$ So, the first diet for humans consisted of a rich variety of fruits, nuts, and grains for sustaining life and enjoyment. ${ }^{4}$ This diet was perfect: rich in nutrition, healthful, and tasty. ${ }^{5}$

'Ellen G. White, Steps to Christ (Boise, ID: Pacific, 1981), 81.

${ }^{2}$ "At no point is anything (human beings, animals, birds) allowed to take the life of another living being and consume it for food" (Hamilton, 140).

${ }^{3}$ In full accord with this standpoint is the prophetic view that the prohibition of eating flesh was never annulled, and that in the New Earth it would be operative again and even the wild animals would then eat only vegetation (Isa 11:7; 65:25). See Cassuto, 58-59.

${ }^{4}$ Ellen G. White, Education (Mountain View, CA: Pacific Press, 1952), 204-205.

${ }^{5}$ Ellen G. White, Counsels on Diet and Foods (Washington, DC: Review and Herald, 1976), 81. 


\section{Periodic Rest}

The Creator, in His wisdom, ordained rest not only for Himself, ${ }^{1}$ but also for human beings and their children. ${ }^{2}$ God believes in rest; at the beginning of the world "he rested on the seventh day from all the work that he had done. So God blessed the seventh day and hallowed it" (Gen 2:2,3). This day was set apart as a special day on a weekly basis for recharging spiritual, mental, and physical wellbeing." "God saw that a Sabbath was essential for man, even in Paradise.... He needed a Sabbath to remind him more vividly of God and to awaken gratitude because all that he enjoyed and possessed came from the beneficent hand of the Creator."4

\section{Temperance}

Right from the beginning, human beings were expected to practice selfcontrol $^{5}$ in regard to their food and at the same time be totally faithful to their Creator. God said, "You may freely eat of every tree of the garden; but of the tree of the knowledge of good and evil you shall not eat" (Gen 2:16-17). "The verse teaches that it is not good for man to acquire the habit of indulging all his desires

'Sailhamer, 97.

${ }^{2}$ Hamilton, 143.

${ }^{3}$ See Exod 20:8-11; Isa 58:13-14; Mark 2:27; Heb 4:9.

${ }^{4}$ Ellen G. White, Patriarchs and Prophets (Boise, ID: Pacific Press, 1958), 48.

5"The virtue of one who masters his desires and passions, especially his sensual appetites (Acts 24:25; 1 Cor 9:25; Gal 5:23" (Merrill F. Unger, The New Ungers Bible Dictionary [1988], s.v. "Self-control"). 
without restraint, and that it is proper for him to discipline himself according to Heaven's precept, and thereby accustom himself to conquer his evil inclination and abstain, when necessary, from temptation."1 It is obvious that self-discipline is the necessary corollary of free will.

The Lord endowed Adam and Eve with free choice, though they belonged to Him by creation and later by redemption. Obedience to Him enables humans to gain true self-control over their lives. It makes an impact not on one part but on every aspect of a human life. ${ }^{2}$ "True temperance teaches us to dispense entirely with everything hurtful and to use judiciously that which is healthful."

\section{Trust in God}

Trust in the Lord, the foundation of spiritual and emotional health, undergirds all the other health provisions God gave to the first couple in Eden. ${ }^{4}$ The Creator wanted Adam and Eve to trust in Him, and after the fall to accept His invitation to come back to Him. God wanted to exchange their heavy burdens for His renewing rest and peace of forgiveness. ${ }^{5}$ The same truth concerns every child

${ }^{1}$ Cassuto, 124.

${ }^{2}$ Samaan, $185,186$.

${ }^{3}$ White, Patriarchs and Prophets, 562.

4" If humans obey the command, they recognize that they do have limitations in the exercise of their God-given responsibilities and that a right relationship to God provides an indispensable matrix for the proper exercise of that power" (Terence E. Fretheim, "The Book of Genesis," The New Interpreter's Bible [Nashville: Abingdon, 1994], 1:353).

${ }^{5}$ Samaan, 197. 
of Adam and Eve today. Ellen G. White said: "Many who profess to be His followers have an anxious, troubled heart, because they are afraid to trust themselves with God." By ignoring God's original plan and choosing sin, human beings began the process of destruction in their own bodies. But God still loves His creation and wants it to be healthy. "The Father's mercy and love have not ceased to flow earthward in rich currents." ${ }^{, 2}$ He wants His people to trust in His Divine power that makes them strong and leads to a healthy and happy life. ${ }^{3}$

Creation week reveals God's original plan for human well-being. The eight fundamental principles of health and a happy life have their beginning in the Garden of Eden. God Himself was the Originator of these principles, and throughout all history He has been interested in a full restoration of fallen human beings.

\section{Health Teachings from the Old Testament Period}

God provided the first couple with an ideal environment and conditions for a healthy, happy, and holy life. His plan was that people would live forever. Unfortunately, Adam and Eve fell into sin, lost their privileges, and were driven out of the Garden of Eden (Gen 3). Now they had to taste the hardships of a sinner's life. In order to get bread Adam had to work in the sweat of his face (vs.

${ }^{1}$ Ellen G. White, The Desire of Ages (Boise, ID: Pacific Press, 1940), 330.

${ }^{2}$ White, Ministry of Healing, 116.

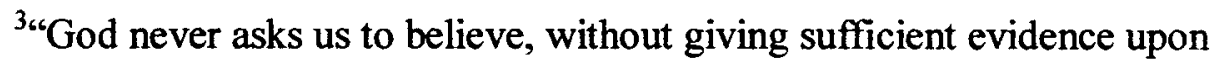
which to base our faith. His existence, His character, the truthfulness of His word, are all established by testimony that appeals to our reason; and this testimony is abundant" (White, Steps to Christ, 74). See also Ps 115:9; Prov 3:5; Isa 26:4. 
19) and to Eve it was said that "in pain" she would "bring forth children" (vs. 16).

From this moment tiredness and pain visited this earth and with them, later on, sickness and death. But God used a healing ministry to the physical needs of sinners as an avenue to present the gospel. ${ }^{1}$

\section{Sickness and Healing}

After the tragic experience of leaving the Garden home, the same lifestyle would maintain health and promote people's restoration if it were followed.

However, some changes took place after the fall. At first, God gave additional food to the first couple, namely, "plants of the field" (Gen 2:5). ${ }^{2}$ They needed them for sustaining their lives outside of Eden. ${ }^{3}$ When Adam's firstborn son lost self-control and trust in God, he and his descendants went astray from God. ${ }^{4}$ In spite of the "painful aftermath of $\sin , "$ the first generations after Adam lived long lives of "exceptional duration," with some over 900 years. ${ }^{7}$ Apparently illness

${ }^{1}$ White, Ministry of Healing, 20.

${ }^{2}$ Jiri Moskala, The Laws of Clean and Unclean Animals of Leviticus 11: Their Nature, Theology, and Rationale (Berrien Springs, MI: ATSP, 1998), 215218.

${ }^{3}$ Only after the Flood was man permitted to eat meat (see Gen 9:1-4). It significantly shortened the life span of a long-lived race (see Ellen $\mathrm{G}$. White, Spiritual Gifts, 4 vols. [Washington, DC: Review and Herald, 1945], 4:120, 121).

${ }^{4}$ White, Patriarchs and Prophets, 78.

${ }^{5}$ Mathews, 295.

${ }^{6}$ Ibid., 302.

${ }^{7}$ Until the Flood many people lived more than 900 years, except Enoch, who was translated to be with God at 365 years of age (Gen 5:21-24). 
was rare-or nonexistent. But the most unfortunate natural consequences of their choices were seen in increasing unhappiness, crime, misery, and death, as people made their individual choices to be loyal to the Creator or to the rebel chief. ${ }^{1}$

By engaging in immorality people not only grieved God, but also brought sickness on themselves and, consequently, a shortened "life span." The OT tèaches that disobedience to God is the cause of disease, while obedience brings happiness, health, and prosperity (Deut 28:1-24). God is the Originator of all natural laws, including the physical, and to ignore them is to invite trouble.

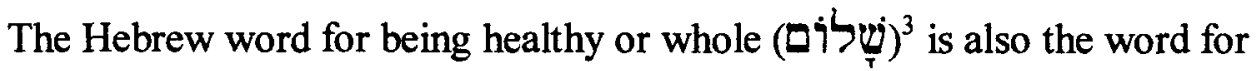
peace, which demonstrates that soundness of body and wholeness of mind have been closely associated in Hebrew thought. Both were God's gifts to His people, as is most evident in the Psalms and Proverbs. ${ }^{4}$

\footnotetext{
${ }^{1}$ Marjorie V. Baldwin, “A Christian Worldview of Healing," Health and Healing 21 (1998): 16.

${ }^{2}$ Wenham, 142.

${ }^{3}$ This word occurs about 250 times in the Hebrew Bible; most frequently in the Psalms (27 times), in the prophetical books of Isaiah (27 times), and Jeremiah (31 times). True ơ comes from God, for human beings find their true wholeness and complete fulfillment only in God. In God alone can individuals know wholeness in all their being and all their relationships which is what the OT means by health.

For the Israelites, health consisted in the wholeness of being and holiness (שT Righteousness (י.? Isa 32:17) also is fundamental to the OT concept of health. Another aspect of physical health is length of life (Gen 15:15; 25:8; Deut 6:2; $30: 20 ; 32: 46-47)$.
}

${ }^{4}$ See Pss 6:2, 3; 31:9, 10; Prov 3:1, 2, 7, 8; 4:20-22; 14:27-30. 
Often Israelites looked upon sickness as a divine judgment for $\sin ^{1}$ While sickness as a judgment from God was the prevalent view in the Old Testament, it was by no means the only one. Maladies could be caused by the "adversary," as in Job's case (Job 2:7), or by jealousy, as on the part of others (Job 5:2). There is also a hint in the OT that some maladies occur naturally, namely, because of old age (Gen $27: 1 ; 48: 1)$. And some misfortunes occurred because of the notions of the people (Gen 34:25).

In spite of sickness, one can see very little evidence of any widespread use of medicine in the OT period, but at the same time healing took place. Natural healing, healing at the direction of God, and prophylactic or preventive healing kept people healthy.

\section{Natural Healing}

"Much of the healing which occurred in Israel must have come about by the operation of natural healing."2 The most sought-after remedies seem to have been of plant origin, such as the balm of Gilead. Jeremiah refers to this popular item: "Is there no balm in Gilead? Is there no physician there?" (Jer 8:22). Moses spoke of using oil as a soothing treatment for the feet: "May he dip his foot in oil"

(Deut 33:24). ${ }^{3}$ Solomon was aware of the interaction between mental and physical illnesses. He wrote, "A cheerful heart is good medicine, but a downcast spirit

${ }^{1}$ John Wilkinson, The Bible and Healing (Edinburgh: Handsel, 1980), 32.

${ }^{2}$ Ibid., 57.

${ }^{3}$ Oil was used like lotion for dry skin. Dry, cracked skin of bare feet needed oil for soothing and healing. 
dries up the bones" (Prov 17:22). ${ }^{1}$ Among several others, natural healing was one aspect of the healing ministry presented in the OT.

\section{Preventive Healing}

Preventive or prophylactic healing is found mainly in the first five books of the Bible and provides for the "restoration of functional wholeness." Modern public health researchers have been impressed with the fact that much of what is now recognized as the area of public health practice is included in the OT prohibitions and codes. They deal with the essentials of air, water, shelter, food, and personal cleanliness. ${ }^{3}$

Dietary restrictions contributed remarkably to the well-being of the Hebrews throughout their generations. These restrictions include abstinence from unclean food, ${ }^{4}$ blood (Lev 17:10), and animal fats (Lev 3:17). Laws of cleanliness and sanitation stressed the importance of personal bathing and washing of garments (Lev 14:8; Jer 2:22; Eccl 9:8), isolation and quarantine (Lev 13, 14; Num $5: 2,3$ ), disposing of all bodily wastes by burial (Deut 23:13-14), and many other related aspects. As a precaution against infection and possibly also against

${ }^{1}$ See also Oliver Leon Larkin, "A Quest for Understanding the Issues in a Healing Ministry at a Local Church" (D.Min. dissertation, Drew University, 1986), $31-41$.

${ }^{2}$ Seward Hiltner, Preface to Pastoral Theology (Nashville: Abingdon, 1958), 90.

${ }^{3}$ Leo R. Van Dolson and J. Robert Spangler, Healthy, Happy, Holy (Washington, DC: Review and Herald, 1975), 33-35.

${ }^{4}$ In Lev 11 one finds the word unclean (טָמא) 34 times, and the word detestable (rpor) 10 times. These regulations were given in regard to specific kinds of animals or creatures which are not to be eaten. 
idolatry, tattooing was forbidden (Lev 19:28). Marriage, as a special gift from God, was sacred. "You shall not commit adultery" (Exod 20:14). This commandment prevented the spread of sexually transmitted diseases among the Hebrews. It also provided other psychosomatic health benefits--peace, contentment, security, etc. Modern research indicates that happily married people live longer then single people. ${ }^{1}$ Sabbath rest (Exod 20:8-11) was perhaps Israel's greatest contribution to mankind. It tells about two vital principles of health: the need for productive labor and the necessity of a day of rest.

Preventive healing like that in the Mosaic code could be of great benefit for a modern society as well. It is "an acceptable healing ministry for the church that has sound biblical support."2

The Greatest Physician

Throughout all the OT one can see that God is not only the Creator who is interested in human well-being, but at the same time $\mathrm{He}$ is the greatest physician. ${ }^{3}$ His plan for His people is excellent health, as well as clear and perceptive minds ready to spread His message all across the world.

${ }^{1}$ William R. Miller and Kathleen A. Jackson, Practical Psychology for Pastors (Englewood Cliffs, NJ: Prentice Hall, 1985), 368-369.

${ }^{2}$ Larkin, 40 .

3"When his people became ill, whether through disobedience or not, the Lord did heal them (Ps 30:2; 103:3; 107:19-20; 147:3; 2 Kgs 20:5)" (Wilkinson, 56). 
God healed His people directly and indirectly. He used His faithful children as channels through whom He could do His "healing activity."1 For example, a little slave girl and Elisha were medical missionaries for Naaman and his family (2 Kgs 5:1-19a). ${ }^{2}$ The Lord chose the prophets and did miracles of healing through them ${ }^{3}$ as may be seen in the case of the prophet Elijah and the widow's son at Zarephath (1 Kgs 17:17-24). Miriam was healed with the aid of her brother Moses (Num 12:9-16). In these cases and other similar ones God was in the business of healing. In the same way God used priests and sacrificial rituals for healing (Lev 14:8-20). The rituals for cleansing or healing were based on the Law of Moses in which there was a complete repudiation of the use of magic. ${ }^{4}$ God alone was the Healer.

As the greatest healer of His people, God is the one who heals the brokenhearted and binds up their griefs (Isa 61:1). He not only forgives sin and heals physical disease, He restores the emotionally wounded as well (Ps 146:7, 8). His plan was that none of the diseases of Egyptians would be upon His people, "For I am the Lord who heals you" (Exod 15:26). But if His people decided to reject Him as their Lord of the covenant, they would reject their Healer. A case in point

${ }^{1}$ Ibid., 61.

${ }^{2}$ Ellen G. White, Prophets and Kings (Mountain View, CA: Pacific Press, 1943), 252-253.

${ }^{3}$ Wilkinson, 59.

${ }^{4}$ Isa 8:19; Lev 19:31; 20:6; Deut 18:10-12. 
is found in the pitiful account of the godless king Jehoram of Judah in $2 \mathrm{Chr}$ 21:4-

20. Because of his persistent sin, the Lord afflicted him with a severe disease for which there was no cure. ${ }^{1}$ According to Brown, any sickness that could not be healed was understood as the result of rejection by the Lord. ${ }^{2}$

Throughout the OT God was always interested in the well-being of His earthly children, and in spite of their unbelief He still wanted to be their spiritual, mental, and physical Restorer. At the same time the Lord needed people through whom He might work, heal, and proclaim the gospel. These were His faithful children who gave all glory back to Him. The prophets and poets of Israel had passionate faith in the Lord their Healer, since He alone could say: "health to you" (Jer 30:17). He alone could cause the dawning of a new day in which the sun of righteousness would rise "with healing in His wings" (Mal 4:2).

\section{Health Teachings from the New Testament Period}

Healing or medical-missionary work was an essential element of the method used for the proclamation of the gospel in the New Testament (NT) period. It was an indispensable part of the overall purpose of God, who from the very

${ }^{1}$ Repeatedly the Scriptures describe God as the cause of sickness (Lev 26:14-16; Deut 28:20-22, 27, 29, 35, 59-61; 1 Sam 5:6-12; 2 Sam 12:15; 1 Kgs 13:4; 2 Kgs 5:27; Job 5:17-18; Ps 38:1-8; Jer 16:3-4; Hos 5:13-6:2). In the Scriptures no event ever takes place in God's absence. From this perspective Bible writers can attribute to God anything that happens within His domain.

. 2 Michael L. Brown, "II Am the Lord Your Healer': A Philological Study of the Root 'Rapa' in the Hebrew Bible and the Ancient Near East" (Ph.D. dissertation, New York University, 1985), 43. 
beginning was engaged in healing ministry, to send His Son to proclaim salvation and healing to the world.

\section{Medical-Missionary Work of Christ}

Jesus Christ came to this earth in order to restore the broken relationship of human beings with the heavenly Father. He came to remove the burden of disease, wretchedness, and sin. It was His mission to bring to the human family complete restoration. ${ }^{1}$ He came to give them health, peace, and perfection of character. His mission included "teaching in their synagogues and proclaiming the good news of the kingdom and curing every disease and every sickness among the people" (Matt 4:23). This verse points out that Christ had a threefold ministry: teaching, preaching, and healing. It is of special interest that He spent more time healing ${ }^{2}$ than $\mathrm{He}$ did teaching and preaching. ${ }^{3}$ It seems He realized that people were not able to receive His spiritual message until they were relieved of their immediate physical ills. ${ }^{4}$

${ }^{1}$ Norman R. Gulley, "Gospel-Medical Evangelism," Syllabus for Medical Evangelism Course, Madison College, n.d., 1:30-31.

${ }^{2}$ In all some 38 accounts of healing by Jesus are recorded in the Gospels. Twenty-six of these concern individual sick persons of whom some details are usually provided, 12 deal with the healing of groups of sick people of whom no individual details are recorded.

${ }^{3}$ E. G. White emphasizes that "the Saviour of the world devoted more time and labor to healing the afflicted of their maladies than to preaching" (Healthful Living [Battle Creek, MI: Medical Missionary Board, 1898], 279).

${ }^{4}$ Hubbard and Hawley, 36. 
Jesus placed a great deal of importance on the faith of those who were seeking healing. ${ }^{1}$ For example, after healing a blind beggar, Christ told the man, "Go; your faith has made you well" (Mark 10:52). ${ }^{2}$ About faith Ellen G. White said, "Faith is a mightier conqueror than death. If the sick can be led to fix their eyes in faith upon the Mighty Healer, we shall see wonderful results. It will bring life to the body and to the soul." In many different ways faith was rewarded in the miracles of healing. Thus the importance of faith was shown as a prerequisite for God's blessings. Likewise spiritual health also depends upon faith. ${ }^{4}$ In that sense, healing helped to teach people the cardinal truth of the gospel that salvation from $\sin$ is by faith.

Christ's healings were full of messages of hope. Through them the love of God was poured out not only to teach the gospel, but also to administer it. Through His mighty works Jesus demonstrated the truth He taught. His parable of the Good Samaritan is a classical illustration of the true idea of medicalmissionary work (Luke 10:30-35). Many have seen in the Samaritan the person of Christ Himself, who came where people were and ministered to their wounds. In His healing ministry is direct evidence of God's limitless love, and such work is "the pioneer work of the gospel.",

'Michael L. Brown, Israel's Divine Healer (Grand Rapids, MI: Zondervan, 1995), 223-224.

${ }^{2}$ See also Luke 7:1-10; 8:45; Mark 9:23.

${ }^{3}$ White, Ministry of Healing, 63.

${ }^{4}$ Wilkinson, 43.

${ }^{5}$ Ibid., 144. 
Jesus used several methods in His healing ministry. He usually healed by word or touch (Mark 1:30,31; Luke 6:6-10). Even more, people filled with faith touched Jesus and found healing (Mark 3:10). The particular instance of this is the woman with the hemorrhage (Luke 8:44). In his Gospel Mark writes that people begged Jesus to allow their sick to touch even the fringe of His cloak "and all those who touched him were cured" (Mark 6:56). Morris Maddocks describes the healing of Jesus: "The faith of the individual, a prayer of thanksgiving, the forgiveness of sins, are further elements that play their part in the healing, but on the whole it is the immediate response of compassion expressed in touch or word that characterizes the ministry of Jesus."1

Jesus' ministry of healing consisted mostly of miracles, which were not only external confirmations of His supremacy and message; rather they were "the vehicle of the message." ${ }^{2}$ His miraculous power of healing created a willingness in people to listen to His teachings. Jesus was, first of all, the Savior, and physical miraculous healings were evidences, signs of His authority. ${ }^{3}$

The medical-missionary work of Christ was not restricted to the Jews.

Even when it was not yet time for the general evangelization of Gentiles, Jesus 1981), 61 .

${ }^{2}$ Raymond E. Brown et al., "The Gospel Miracles," The Jerome Biblical Commentary, vol. 2 (Englewood Cliffs, NY: Prentice-Hall, 1968), 787.

${ }^{3}$ George W. Reid, "Health and Healing," in Handbook of Seventh-day Adventist Theology Commentary Reference Series, ed. George W. Reid (Hagerstown, MD: Review and Herald, 2000), 766. 
began to break down these barriers. ${ }^{1}$ He healed the daughter of the

Syrophoenician woman (Mark 7:24-30), a centurion's servant (Matt 8:5-13), and among the Gerasenes a demon-possessed man (Mark 5:1-20). Doing this, Christ showed in practice the true medical-missionary spirit; and Gentiles received healing by the same channel as Jews - through faith in Jesus who healed physically, mentally, and spiritually. His healing ministry was for the healing of the nations as well as for the healing of His own people (Isa 42:5-7, 16).

\section{Christ's Commission to His Disciples}

The NT acquaints the reader not only with Christ's healing ministry, but also with His commission to His disciples to continue the work of healing and preaching. Luke's account clearly tells about this continuity: "Then Jesus called

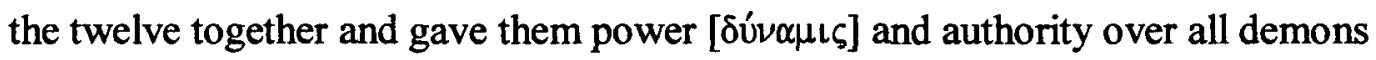

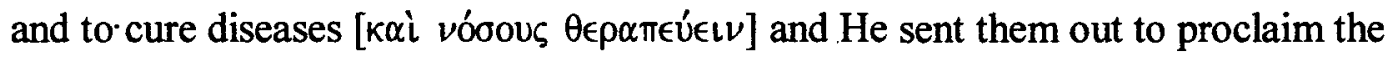

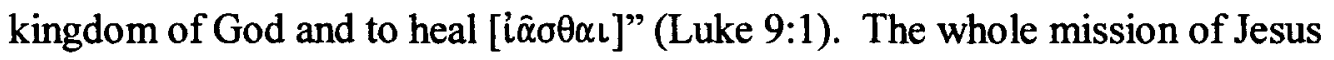
(Luke 4:14, 36), and especially His healing ${ }^{2}$ (Luke 5:17, paralytic; 8:46, bleeding

${ }^{1}$ White, Reflecting Christ, 19.

${ }^{2}$ A survey of the occurrence of the word health and its synonyms, which are used in the NT to denote health, is impressive: the word ióoual is translated

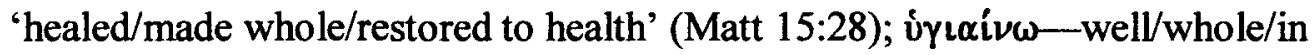

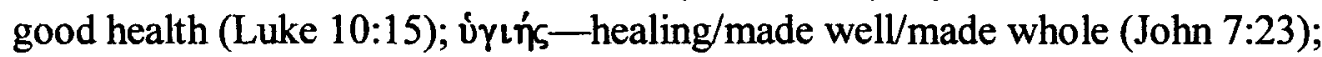

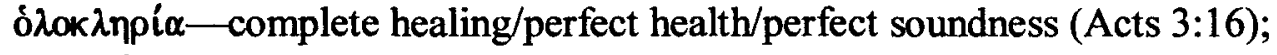

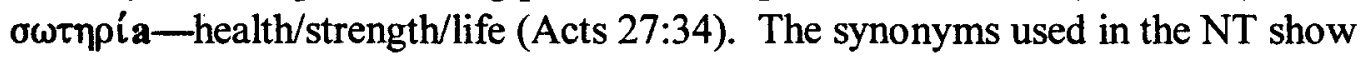
how similar the concept of health is to the OT concept of $ם$ iț. Health is thought of in terms of wholeness, well-being, soundness, life, strength, and salvation. All these are facets of the NT understanding of health and express ideas which have already been found in the OT. Wilkinson, 8-12. 


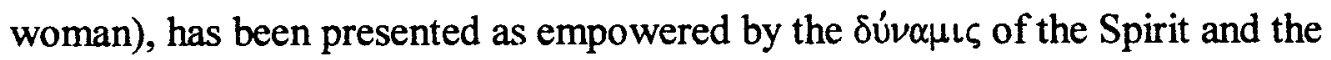

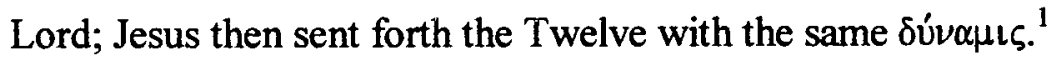

Jesus entrusted His disciples with the same message as that of John the Baptist and Christ Himself: "The kingdom of heaven is at hand" (Matt 3:2; 4:17; Mark 1:15). "In His name they were to do the same work of mercy as He had done." ${ }^{2}$ He commanded, "Cure the sick, raise the dead, cleanse the lepers, cast out demons. You received without payment; give without payment" (Matt 10:8). God expected His disciples to use whatever He had given them and to share it with others. Ellen G. White said, "The disciples were to go as His representatives."3 They were called to do the medical missionary work of "unlocking the hearts of humans." ${ }^{, 4}$

\section{Medical-Missionary Work of the Apostles}

After the resurrection Jesus sent His disciples to experience again the first vision of their calling. In the book of Acts the physician Luke shows how in the power of the Holy Spirit Christ's disciples (apostles) carried out their commission. They not only preached the Word, but also did miracles of healing. Ten specific

${ }^{\mathrm{I}} \mathrm{M}$. Dennis Hamm, "This Sign of Healing, Acts 3:1-10: A Study in Lucan Theology" (Ph.D. dissertation, Saint Louis University, 1975), 51.

${ }^{2}$ White, Desire of Ages, 350.

${ }^{3}$ Ibid., 351.

${ }^{4}$ William Dysinger, Heaven's Lifestyle Today (Silver Spring, MD: General Conference of Seventh-day Adventists, Ministerial Association, 1997), 103. 
healings and ten other cases of healing are described in summary. ${ }^{1}$ In these, hundreds were healed, clearly testifying about God's loving care for His earthly children. The healing provides a literally heaven-sent opportunity for proclaiming the good news of Jesus Christ (Acts 4:10,12).

The healing ministry of the apostles greatly influenced the spread of the gospel and occurred at certain key points of the mission. The healing of the lame man (Acts 3) gave emphasis to the events of Pentecost (Acts 2). The healing of Saul's sight led to the greatest missionary career in the church's history (Acts 9:17-19). The exorcism of the Philippian slave girl led to major opportunities for evangelism in what became the first Christian church in Europe (Acts 16).

It was natural that the healing work of the early Christian community should take place in an evangelistic context. ${ }^{2}$ Just as Jesus had shown His love for others in ministering to people and healing their sicknesses, so the apostles and their helpers had an intense desire to continue their Lord's ministry. ${ }^{3}$

At the same time the apostles, following God's example, used not only a ministry of healing the sick, but also spread preventive healing. ${ }^{4}$ They recognized

${ }^{1}$ Maddocks, 81.

${ }^{2}$ F. Graber and D. Muller, "Heal," The New International Dictionary of New Testament Theology (1986), 2:169.

${ }^{3}$ White, Ministry of Healing, 141.

${ }^{4} 3$ John 2 tells the reader that John's wish was to see Gaius spiritually and physically healthy. Though the text does not elaborate on health issues, the idea of a preventive healing is implied. 
the importance of diet to good health (Phil 3:19; Eph 5:18; 1 Cor 10:31; Rev 22:1, 2). The NT writers warned against sexual immorality, which causes emotional, physical, and spiritual health problems (1 Thess 4:3-5; 1 Cor 6:9, 10). The need of adequate exercise (1 Tim 4:8) through productive labor was also stressed several times in Paul's writings (1 Cor 9:24-27; 1 Thess 4:11).

The gospel ministry of the apostles included medical-missionary work, which is "a corollary of relationship with God." The purpose of such ministry was to bring people closer to God and acquaint them with their personal Savior. "James (5:13-18) is quite clear that healing is always more than physical for it includes the whole being of the human person."2

This brief research clearly demonstrates the reality of and need for a healing ministry which is reflected throughout the whole Bible like a golden thread. Such a ministry points to God's love and care in regard to the wholeness of human beings and His concern for their salvation. The Bible contains a solid foundation and rich information regarding the wholistic health approach and ministry that could be useful for Seventh-day Adventist health evangelism in Latvia.

${ }^{1}$ Mike Flynn and Doug Gregg, Inner Healing (Downers Grove, IL: InterVarsity, 1993), 49.

${ }^{2}$ Wilkinson, 245. 


\title{
CHAPTER 5
}

\section{HISTORICAL DEVELOPMENT OF SEVENTH-DAY}

\section{ADVENTIST HEALTH EVANGELISM WORK}

\begin{abstract}
After surveying the biblical foundation for health evangelism, it is important to explore the beginnings and historical developments of Adventist health evangelism work. Some of the points of special interest are: health practices in the early nineteenth century in America; E. G. White and her contribution to the early Adventist movement; concepts of wholistic health ministry and approaches used by Adventists which led to health evangelism; and finally, the progress of medical-missionary work in Europe.
\end{abstract}

\section{Background: Health Practices in the Early Nineteenth Century}

Health evangelism is an aspect of gospel work that presents basic health principles and offers practical instructions for sensible health habits. ${ }^{1}$ The concept includes everything that positively contributes to the health of the body, mind, and soul. Health evangelism occupies an important role in the SDA church and sets Adventists apart from most other Christians. The development and practical

\footnotetext{
${ }^{1}$ Williams, Kuzma, and Van Dolson, 59.
} 
implications of a particular teaching of health and healing have become an integral part of their beliefs.

The true science of healthful living was little known by anyone in the beginnings of the advent movement. For example, most people were afraid of the "deadly night air."1 They closed their windows to keep the fresh air out of every sleeping room. Doctors and nurses knew almost nothing of the relationship between diet and health. They administered powerful poisonous drugs and subjected the patients to repeated bleedings and purgings.

\section{Heroic Practice}

The last part of the eighteenth century and the beginning of the nineteenth century have become known as the era of heroic ${ }^{2}$ medicine. Benjamin Rush is a famous representative of this school of practice in America. Heroic prescriptions became normative for almost all people. Those physicians who denied them were criticized by their colleagues. ${ }^{3}$ Most people believed that they had to undergo

'Ellen G. White, "Disease and Its Causes--Impure Air," Review and Herald, 5 December 1899, 786.

${ }^{2}$ Heroic medicine used extreme means to get a necessary result, especially by employing extraordinary medical procedures to keep a patient alive. See Robert K. Barnhart, "Heroic," The World Book Dictionary, 2 vols. (Chicago: World Books, 1995), 1:993.

${ }^{3}$ William G. Rothstein, American Physicians in the Nineteenth Century: From Sects to Science (Baltimore, MD: Johns Hopkins University Press, 1972), 41-43. 
massive bloodletting and to submit themselves to the violent purgatives and emetics that were prescribed by the medical doctors. ${ }^{1}$

In fact, bleeding had been common for centuries. Even in the mid-1800s, pharmacies still had pots of leeches, bloodsucking worms, on their shelves. ${ }^{2}$ Dr. Gallup, believing that too much blood caused inflammation and fever, removed blood ounce after ounce. Usually his patient's temperature would drop. Many people, including George Washington, thus were bled to death. ${ }^{3}$

In heroic medicine, physicians also prescribed various kinds of drugs in order to induce vomiting. For example, calomel (chloride of mercury) was used for almost every complaint. ${ }^{4}$ The literature of the nineteenth century is full of references to drugs such as tartar emetic (a lethal poison that lowered body temperature), nitre (that depressed heartbeat), jalab (a violent purgative), and many others. ${ }^{5}$ Dr. Hooker used to denounce quackery, homeopathy, and the medicines of the late sixteenth century, but on the other hand he stated with all sincerity, "Mercury is a remedy of great value in the treatment of many chronic diseases," and "opium is the most important of all drugs that are employed in the treatment of

${ }^{1}$ For cleansing processes physicians used two kinds of drugs: "emetics which produced emesis or vomiting, and cathartics or purgatives which acted as extremely powerful laxatives" (ibid., 49).

${ }^{2}$ George Griffenhagen, The Story of California Pharmacy (Madison, WI: American Institute of the History of Pharmacy, 1950), 20.

${ }^{3}$ Rothstein, 55.

${ }^{4}$ George Wayne Reid, "The Foundations and Early Development of the Health Emphasis Among Seventh-day Adventists" (Th.D. dissertation, Southwestern Baptist Theological Seminary, 1976), 65.

${ }^{5}$ Ibid., 66. 
disease."1 Finally, apothecaries (druggists) could diagnose illness, prescribe, and sell any medicine or drug. In fact, anyone could be an apothecary. ${ }^{2}$

During that period American physicians did not do much research and thus they were far behind their European colleagues in the study of physiology and pathology. "Although by the 1830 s doctors in Paris and Vienna had shown the futility of 'bleeding and purging' and were discontinuing the heavy use of drugs, it was several decades before these ideas were generally accepted by American physicians. ${ }^{33}$

\section{Theories of Disease}

In 1800 , the true nature of disease was a matter of best guess and was clouded by an accumulation of theories, some of which were too extreme. Many physicians held up to ten or more different theories. Many dedicated Christians believed that the illness was sent as a divine affliction, and clergymen, some of whom were giving medical counsel, supported such ideas. ${ }^{4}$ People could better

\footnotetext{
${ }^{1}$ Worthington Hooker, Rational Therapeutics (Boston: John Wilson and Sons, 1857), 40.

${ }^{2}$ John Ferriar, Medical Histories and Reflections (Philadelphia, PA: Thomas Dobson, 1816), 19. See also Adelaide Hechtlinger, The Great Patent Medicine Era, or, Without Benefit of Doctor (New York: Galahad Book, 1970); Jacob Bigelow, Brief Exposition of Rational Medicine (Boston: Philips, Samson, and Company, 1858).
}

${ }^{3}$ Richard William Schwarz, "John Harvey Kellogg: American Health Reformer" (Ph.D. dissertation, University of Michigan, 1964), 98.

${ }^{4}$ Otho T. Beall, Jr., and Richard H. Shryock, Cotton Mather: First Significant Figure in American Medicine, Publications of the Institute of the History of Medicine, First Series (Baltimore, MD: Johns Hopkins University Press, 1954), 5:54-58. 
understand sickness and pain when somebody used theological terminology. All human suffering found in this world was believed to be a result of Adam's fall and that healing could be achieved only through prayer and forgiveness. Whatever happened in a human life was a fulfillment of God's will.

In spite of the fact that the above-mentioned beliefs were highly popular in the first part of the nineteenth century, they were heavily attacked by new secular developments, philosophies, and ideologies. Horace Mann ${ }^{1}$ wrote, in 1842, about "sufferings and calamities of my fellow-beings which seem to me to be no part of the ordination of a merciful Providence, but to be directly chargeable to human ignorance and error."2

Another view, the so-called filth theory of disease, was not so much a theory as a methodological approach, which played an important role in that society. It was observed that some infectious diseases came as a result of association with filth and this led many people to the conclusion that filth was the real cause of disease. "This [partly] erroneous conception led to an unparalleled war against dirt and nuisances, great improvements in the conveyance and disposal of sewage." 3

${ }^{1}$ Horace Mann "played a leading role in establishing state-supervised, statefunded, mandatory-attendance school system in the United States" (Glenn Smith, "Mann, Horace," World Book Encyclopedia [1996], 13:164).

${ }^{2}$ Horace Mann, "The Study of Physiology in the Schools," in Annual Reports on Education, ed. Mary Tyler Mann, vol. 3 of Life and Works of Horace Mann (Boston: Horace B. Fuller, 1868), 226-227.

${ }^{3}$ Charles Singer and Ashworth Underwood, $A$ Short History of Medicine, $2^{\text {nd }}$ ed. (New York and Oxford: Oxford University Press, 1962), 231. 
Even more, some believed that diphtheria was the result of association with evil smells, which were coming from filth, and likewise the cause of many other diseases was found in the same source. In the nineteenth century people experienced three major epidemics of cholera that, including typhoid, were believed to be either divine judgment sent upon the sinners or caused by miasma, an evil essence which arose from filth, garbage, or marshes. ${ }^{1}$ Naturally, the therapy for the latter was to start clean-up movements and to drain marshes near densely populated areas. It was this theory which led to the striking progress in sanitation. ${ }^{2}$

Other theories were: the mathematical theory, fluid theory, soul theory, stimulation theory, Broussais's irritation theory, and so on. ${ }^{3}$ Amid these numerous theories of disease, the ancient concept of the healing power of nature began to be rediscovered. The health reformers of the nineteenth century were uncovering a theory, only to find themselves confronted with the almost standardized opposition of the regular medical practitioners. Physicians labeled them as empirical rustics, who were attempting to restore what should be regarded as a discredited element of a primitive medicine. ${ }^{4}$

${ }^{1}$ Ibid., 232.

${ }^{2}$ Reid, "The Foundations and Early Development of the Health Emphasis Among Seventh-day Adventists," 57.

${ }^{3} \mathrm{~A}$ number of the popular theories are summarized in Wyndham E. B. Loyd, A Hundred Years of Medicine, $2^{\text {nd }}$ ed. (London: Gerald Duckworth \& Co., 1968).

${ }^{4}$ Singer and Underwood, 111. 


\section{Sylvester Graham}

Sylvester Graham (1794-1851) was one of the earliest American health reformers. He first became involved in the temperance movement, then in hygienic and dietary reforms. His basic theory was simple--to return to the concept of the healing power of nature. According to Shryock, Graham believed that "right living was a more certain means to health than was a resort to doctors and drugs."

Graham strongly believed that God created human beings, and that human nature was governed by natural laws. Therefore he emphasized and promoted the belief in vital forces. In spite of the fact that these ideas were already known in the past, in his day they were considered completely wrong by the medical professionals. Graham's theory taught that man was endowed from birth with a vital force of energy, which, attacked by disease, responds in conflict. ${ }^{2}$

Graham pointed out that whatever a person does, including physical and mental activities, affects positively or negatively on one's life force. Above all, he was a proponent of a moderate diet, including vegetarianism and whole wheat products. He praised the virtues of bathing, of fresh air, sunlight, reform of dress, sexual hygiene, and exercise. ${ }^{3}$ According to him, the ideal diet should be simple and as free as possible from strong spices and stimulating ingredients. As part of his program, Graham condemned tobacco, tea, coffee, cordials, tonics, fermented

${ }^{1}$ Richard H. Shryock, Medicine in America, Historical Essays (Baltimore, MD: Johns Hopkins University Press, 1966), 120.

${ }^{2}$ Reid, "The Foundations and Early Development of the Health Emphasis Among Seventh-day Adventists," 83.

${ }^{3}$ Shryock, 114. 
or distilled alcoholic liquors, opiates, and other common drugs used in the name of medications or preventives. ${ }^{1}$ With prophetic tone he pronounced, "All these things necessarily prepare for consumption [tuberculosis]."2

However, Graham's greatest contribution to the health reform movement was his theory in which he bound together health with morality aspects. He was convinced that "a gross state of sensuality, and consequent intellectual and moral stupidity and darkness," was in sharp disharmony with spiritual life. ${ }^{3}$ Graham united the ideal of sensible living with good health in all its phases -"a sound body and a sound mind."

As the popularity of Graham's movement grew and spread, resistance arose from many sides, namely, from tavern keepers, millers (defending their white flour), butchers, physicians, and others. By 1840 , the public became tired of Graham's theories and of his reform movements, which started to lose their power and influence on the masses. However, the once popular health movement with its practices left its impact on many thinking Americans. In spite of the fact that the enthusiasm and controversy declined during the early 1840 s, the movement was not dead.

'George R. Knight, Ellen White's World (Hagerstown, MD: Review and Herald, 1998), 35.

${ }^{2}$ Ibid., 27-30.

${ }^{3}$ Sylvester Graham, Lectures on the Science of Human Life, 2 vols. (Boston: Marsh, Capen, Lyon, and Webb, 1839), 1:441.

${ }^{4}$ Shryock, 114. 
The Adventist Movement and the Role of Ellen G. White

Early Adventists before 1863

Early Adventists were not health reformers, or even health practitioners. They did not understand the evil effects of tobacco, improper diet, and wrong habits upon the body, mind, and soul. Children died through ignorance of health practices and ignorance of simple home treatments. ${ }^{1}$ However, the time was coming when a flood of light on healthful living would be given to the Adventist believers, and they would emphasize the relation of a strong body and a sound mind to spiritual living.

Joseph Bates, who has been called "the father of the Sabbath truth among Seventh-day Adventists, ${ }^{, 2}$ began practicing a temperate and healthful lifestyle as early as 1822 and was active in the temperance cause when he learned of the Advent movement. He urged others to join him. Some people did, but many pioneers of the movement were indifferent to his message. ${ }^{3}$

Bates quickly was drawn into leadership. After the Great Disappointment, Joseph Bates discovered the Sabbath truth and with James and Ellen White became one of the top three leaders in the rising Seventh-day Adventist

\footnotetext{
${ }^{1}$ Richard A. Schaefer, Legacy (Mountain View, CA: Pacific Press, 1977), 12.

${ }^{2}$ C. Mervyn Maxwell, Tell It to the World (Mountain View, CA: Pacific Press, 1977), 76.
}

${ }^{3}$ Anne Devereaux Jordan, The Seventh-Day Adventists: A History (New York: Hippocrene Books, 1988), 103-194. 
movement. ${ }^{1}$ Although Bates was practicing many of the principles of health reform before $1844,{ }^{2}$ he did not popularize these subjects until after Ellen White's vision of 1863 . No doubt, his example was noticed by many people, for at the time when many of the leaders of the new church were often weak and sick, Joseph Bates could state at seventy-nine, "I am entirely free from aches and pains!"3

However, in 1849 in the context of spiritual preparation for the second Coming of Christ, Joseph Bates spoke out against tobacco, snuff, and alcohol, stressing 'the necessity of the cleansing of body and spirit, and perfecting holiness ( 2 Cor 7:1; Isa 52:11), because continuation of defiling practices would prevent entrance into the New Jerusalem (Rev 21:27)."

During this period, Adventists suggested several other reasons for abstaining from bad habits. James White believed and preached that the Holy Spirit cannot dwell in those who use tobacco, snuff, and tea. ${ }^{5}$ Adventist believers noticed a relationship between spirituality and health, and frequently referred to

${ }^{1}$ Maxwell, 79.

${ }^{2}$ Dores Eugene Robinson, The Story of Our Health Message (Nashville, TN: Southern Publishing Association, 1943), 50, 51.

${ }^{3}$ Ibid., 80 .

${ }^{4}$ Damsteegt, 226.

${ }^{5}$ Ibid., 224. 
1 Cor 3:16-17 and 1 Cor 6:19, where the believer's body is compared with the temple of the Holy Spirit. ${ }^{1}$ The concept of Gloria Dei was also used to encourage healthful living. This was supported by 1 Cor $6: 20$, "For you were bought with a price; therefore glorify God in your body" and 1 Cor 10:31, "So, whether you eat or drink, or whatever you do, do everything for the glory of God."2 George Reid summarizes their philosophy of healthful living in these words: "If the Christian would do all to the glory of God, he would eschew any damaging product."”

Another important appeal was based on stewardship. As the young Adventist church began to grow, there was an urgent need of financial support. ${ }^{4}$ Therefore, in 1854 Ellen White passionately called for a victory over unhealthful habits and appetite so that money saved in this way could be "put into the treasury of the Lord."

The early church's growing faith in Ellen White's gift of prophecy also played an important role. Her first health vision in the autumn of 1848 revealed the "injurious effects of tobacco, tea, and coffee." It is interesting to note that

${ }^{1}$ In 1 Cor 3:16-17 "you" is plural, referring to the church (congregation) as Christ's body and in 1 Cor 6:19 "you" is singular, referring to the individual human physical body.

${ }^{2}$ Damsteegt, 225.

${ }^{3}$ George W. Reid, $A$ Sound of Trumpets (Washington, DC: Review and Herald, 1982), 65.

${ }^{4}$ Damsteegt, 227. 1945), 122.

${ }^{5}$ Ellen G. White, Early Writings (Washington, DC: Review and Herald, ${ }^{6}$ Ibid., 222. 
some reforms, such as abstinence from swine's flesh, were rejected as premature

by the church leadership. D. E. Robinson, former secretary to Ellen G. White,

points out why:

There were, however, other reforms to be adopted before the Sabbathkeeping Adventists were ready to accept the health reform principles. It is a well-known proclivity of human nature to rise up against any interference with self-indulgent habits. Had the health message, with its call to self-denial, been introduced prematurely, it might have caused distraction and brought in confusion. It seems to have been in the providence of God, therefore, that the great fundamental spiritual truths should be presented first. By these the body of believers was unified and knit together before it was to be tested by the introduction of the health reform message, which, though a matter of great importance, was nevertheless secondary.

By 1863 the doctrinal foundation of the Seventh-day Adventist church had been laid and its organizational structure was in place. Friday night, June 6, 1863, only fifteen days after the General Conference of Seventh-day Adventists was organized, God gave Ellen White a major vision concerning health. ${ }^{2}$

\section{${ }^{1}$ Robinson, 54.}

${ }^{2}$ The first-known vision relating to health concerns was given in the autumn of 1848. She saw that tobacco was a filthy weed and must be given up, and that tea and coffee were also injurious. A second, limited, view was presented on February 12, 1854. White saw that the houses of the saints should be kept tidy and neat, free from dirt and filth and all uncleanness, and the appetite must be denied. The third (and major) vision was given the evening of Friday, June 5, 1863 , at Otsego, Michigan (it is commonly dated to June 6 because by the biblical reckoning the day begins at sunset, therefore Sabbath, June 6, had already begun). The last of the first four (and $2^{\text {nd }}$ major) health reform visions would come two years later, on Christmas Day, 1865, in Rochester, NY, during the service especially called to pray for the restoration of James White's deteriorating health condition. In this vision the Lord pointed out that the church did not respond to the light on health reform as it should have. The little church was also instructed to begin medical evangelism by building a denominational health institution. See Van Dolson and Spangler, 63-65. 
Changes after E. G. White's 1863 Health Vision

The year 1863 became a turning point in the Adventist movement in regard to health issues. At the beginning of the Sabbath, family and visitors assembled for songs and prayer at the home of brother A. Hilliard in Otsego, Michigan. While Ellen White was praying, she was taken off into a vision. The vision continued for about forty-five minutes, while she was introduced to the broad outlines of the subject of health reform. The next day she wrote about the content of that vision:

I saw that it was a sacred duty to attend to our health, and arose others to their duty. ... We have a duty to speak, to come out against intemperance of every kind--intemperance in working, in eating, in drinking, in drugging, and then point them to God's great medicine, water, pure soft water, for diseases, for health, for cleanliness, for luxury. . . . I saw that we should not be silent upon the subject of health, but should wake up minds to the subject. ${ }^{1}$

In the vision were included specific details which greatly broadened Adventist understanding of health reform. But the outstanding feature of the vision seems to be its revealing to early Adventists their "duty to elevate by precept and example the principles of temperance and of health reform, by giving them a place with other saving truths, as an integral part of the message to prepare a people for Christ's coming."”

The health reform message was integrated with the third angel's message, especially Rev 14:12: "those who keep the commandments of God." Damsteegt points out why health reform was seen as part of this message. He writes:

\footnotetext{
${ }^{1}$ Ellen G. White, Letter 4, 1863, quoted in Robinson, 67.

${ }^{2}$ Robinson, 69.
} 
A basic principle in health reform indicated transgression of the laws of the human organism was a moral issue, and thus sinful, so that transgression of these laws could be considered as transgression of God's law, the Decalogue. It was at this point that the integration of health reform into the third angel's message took place, because its central theme summoned the observance of God's commandments (Rev 14:12). Therefore, health reform by calling people to obedience to the laws of nature supported obedience to God's commandments, an object similar to the mission of the third angel's message. ${ }^{1}$

After Ellen White's 1863 health vision, Adventists began to see the health reform as part of the third angel's message. They saw violation of health principles as disobedience to both moral and natural law and as having negative effects on one's spirituality. Even more, in 1867 E. G. White informed the church that the health reform "is a part of the third angel's message and is just as closely connected with it as are the arm and hand with the human body."2

In $1866, \mathrm{~J} . \mathrm{H}$. Waggoner also pointed out that it was the doctrine of the Second Coming that gave doctrinal importance to Adventist teachings on health. At the same time, he confirmed that Adventists do not profess to be discoverers of the general principles of the health reform:

We do not profess to be pioneers in the general principles of the health reform. The facts on which this health reform is based have been elaborated, in a great measure, by reformers, physicians, and writers on psychology and hygiene, and so may be found scattered through the land. But we do claim that by the method of God's choice it has been more clearly and powerfully unfolded and is thereby producing an effect, which we could not have looked for from any other means.

As mere physiological and hygienic truths, they might be studied by some at their leisure, and by others laid aside as of little consequence; but when placed on a level with the great truths of the third angel's message by the sanction and authority of God's Spirit, and so declared to be the means whereby a weak people may be made strong to overcome, and our diseased bodies cleansed and fitted for translation, then it comes to us as an essential

${ }^{1}$ Damsteegt, 229.

${ }^{2}$ White, Testimonies for the Church, 1:486. 
part of present truth, to be received with the blessing of God, or rejected at our peril. $^{1}$

This lengthy statement, quoted by almost every Adventist writer dealing with the history of Adventist health reform, declares that preparation for translation at Jesus' Second Coming was the motivating factor in the development of Adventist teachings on health. Many other doctrines adopted by early Adventists contributed to the formation of a doctrine of health, but this driving desire to be ready for Jesus' soon coming was the main motivation of health reform.

\section{Adventist Concepts of Wholistic Health Ministry}

Approaches Used by Adventists

Seventh-day Adventists used several approaches to explain that abuse of the laws of the human organism is sin. Ellen G. White's counsel concerning medical-missionary work as an inseparable part of the Christian gospel brought new insights on wholistic health ministry. ${ }^{2}$

In the most important of these approaches, Adventists saw physical injury to their own lives or the lives of others as a direct violation of the sixth commandment. J. H. Waggoner wrote: "It is morally wrong, according to the sixth 77.

'J. H. Waggoner, "Present Truth," Review and Herald, 7 August 1866, 76,

${ }^{2}$ White, Ministry of Healing, 88, 89. 
commandment, to do anything tending to abridge the lives either of ourselves or others."1

Another approach saw the laws of the human organism as created by God, just as God created the body itself. Ellen White pointed out that "God has formed laws which govern our constitutions, and these laws which he has placed in our being, are divine, and for every transgression there is affixed a penalty, which must sooner or later be realized." ${ }^{2}$ This, according to Damsteegt, suggests that the law of God includes both the moral law and the laws of the human organism. Early Adventists saw transgression of either law as a sin.

A third approach was the most revolutionary. It "viewed the violation of the laws of nature by its consequences on the body." Damsteegt coins the phrase "soma-psycho-pneumatic" to describe these consequences because "each violation of the laws of health affected the physical, mental, and spiritual constitution of man."4

An example of Ellen White's use of the soma-psycho-pneumatic principle was the experience of Nadab and Abihu (Lev 10:1-2), where fermented wine first impaired their minds, and then in turn affected their spirituality. The obvious conclusion to be drawn was that "if violation of the laws of the human organism

'J. H. Waggoner, "Moral Duty of Preserving Health," Health Reformer, February 1872, 51, quoted in Damsteegt, 230.

${ }^{2}$ Ellen G. White, "Parents Their Own Physicians," Health Reformer, October 1866, 36, quoted in Damsteegt, 230.

${ }^{3}$ Damsteegt, 230.

${ }^{4}$ Ibid. 
would lessen one's spiritual discernment, it would also negatively affect one's obedience toward the moral law of God."'

This approach was revolutionary because it was at odds with the religious and emerging scientific theories of the time. In science a mechanistic approach to health care was gaining ground in which the attention was shifting from man to microbe. Very little attention was given to the interrelationship between mind and body. In fact, Adventist teachings were considered more reactionary than revolutionary, but today's research confirms the benefits of the Adventist wholistic approach to health. ${ }^{2}$

\section{Health and Wholeness}

The Adventist argument that "a person's moral and spiritual nature is largely affected by his physical condition"3 grew out of the church's understanding of the nature of man-a view at odds with most other Christian theories of man. Reid emphasizes the Adventist doctrine:

Rejecting the Hellenistic separation of body from soul and its corollary, the immortal soul theory, Adventists follow instead the unitary view characteristic of Hebrew thought. Body and spirit are united in a single person, designated 'mortal man.' Life, then, is a continuing gift of God, moment by moment, not a state conferred at some point in the past. Therefore life exists only as long as its flow continues from God, the sole source of life. ${ }^{4}$

${ }^{1}$ Ibid., 231.

${ }^{2}$ Reid, A Sound of Trumpets, 117-118.

${ }^{3}$ Ibid., 126.

${ }^{4}$ Ibid., 127. 
This "holistic Adventist view of man" became "a major building block in the church's medical philosophy," for "if a man is a whole, God must save him as a whole." If the Advent hope in the Second Coming is the major motivation of their health tradition, then the Adventist wholistic view of man is like glue, which holds the many parts of the Adventist doctrine of health together. 1 Thess 5:23 is a key text that was used by Ellen White and others. ${ }^{2}$ It points out that the doctrine of the Second Coming and the nature of man were combined to give the doctrine of health a major place in the third angel's message: "And the very God of peace sanctify you wholly; and I pray God your whole spirit and soul and body be preserved blameless unto the coming of our Lord Jesus Christ" (1 Thess 5:23). The Adventist health reform sought to preserve believers' bodies as well as their minds and spirits until Jesus' Second Coming.

\section{Step-by-Step in Health Evangelism}

After 1863 another development took place. Ellen White had seen in her vision on health that "we should not be silent upon the subject of health, but should wake up minds to the subject,", and "nothing will open the doors for the truth like evangelistic medical work. Doors that have been closed to him who

${ }^{1}$ Ibid., 127-128.

${ }^{2}$ Damsteegt, 236.

${ }^{3}$ Ellen G. White, Selected Messages (Hagerstown, MD: Review and Herald, 1980), 3:280. 
merely preaches the gospel will be opened to the intelligent medical missionary."1 Here in a nutshell is the main reason for the tremendous emphasis on health evangelism among Adventists. They understood that this kind of evangelism or medical missionary work is not an end in itself, but a means to an end. It was designed to open doors for the rest of the gospel.

Another term used to designate the same significant concept is often called the "entering wedge." White pointed out, "I can see in the Lord's providence that the medical missionary work is to be a great entering wedge, whereby the diseased soul may be reached." Health evangelism is not only identified as an "entering wedge" to attract a person's attention to the gospel, but also plays a vital part in the preparation of the mind for the reception of truth. "He designs that the subject shall be agitated, and the public mind deeply stirred to investigate it; for it is impossible for men and women, while under the power of sinful, healthdestroying, brain-enervating habits, to appropriate sacred truth."3

Thus Adventists became conscious of the evangelistic potential of the health message. They saw it as a means of preparing the ground for the third angel's message. Health reform became not only a result of the fact that people accepted the third angel's message, and it not only prepared one for the second 513.

${ }^{1}$ Ellen G. White, Evangelism (Washington, DC: Review and Herald, 1946),

${ }^{2}$ Ellen G. White, Counsels on Health and Instruction to Medical Workers (Mountain View, CA: Pacific Press, 1923), 535.

${ }^{3}$ Ibid., 21. 
coming of Christ, but it also became an opportunity to prepare people for better understanding the message in the first place.

On the other hand, in spite of the fact that healthful living was to play a major role in preparing people for Christ's Second Coming, Ellen White warned against it being misunderstood as the third angel's message. She wrote, "The Health Reform is closely connected with the work of the third angel's message, yet it is not the message. Our preachers should teach the Health Reform, yet they should not make this the leading theme in the place of the message. Its place is among those subjects which set forth the preparatory work to meet the events brought to view by the message, among which it is prominent."

No wonder that three points are distinguished clearly in the writings of Ellen White. First, she writes in regard to the evangelistic role of physicians and explains that evangelism is not to be done independently from the health message.

Let the medical workers present the important truths from the physician's viewpoint. Physicians of consecration and talent can secure a hearing in large cities at times other men would fail. As physicians unite with ministers in proclaiming the gospel in the great cities of the land, their combined labors will result in influencing many minds in favor of the truth for this time. ${ }^{2}$

The presentation of the Adventist health message with the other doctrines does not mean that the success of an evangelist is undermined. On the contrary, this combination could only boost it. Only three years after Ellen White's vision, the Western Health Reform Institute was established in Battle Creek, Michigan. Its purpose was not only to help church members, but it was also to be a place

\footnotetext{
${ }^{1}$ White, Testimonies for the Church, 1:559.

${ }^{2}$ Ellen G. White, Medical Ministry (Boise, ID: Pacific Press, 1963), 248.
} 
where unbelievers could be brought directly under the influence of the truth. ${ }^{1}$ James White stated that "its mission is to contribute to the improvement of mankind physically, mentally, and morally.",2

Second, beyond the health evangelism of physicians, Ellen White received a vision directing that every minister was to become involved in medical missionary work.

Medical missionary work ... is to be connected with the gospel ministry. It is the gospel in practice. I wish to tell you that soon there will be no work done in ministerial lines but medical missionary work. The work of a minister is to minister. Our ministers are to work on the gospel plan of ministering. ... You will never be ministers after the gospel order till you show a decided interest in medical missionary work, the gospel of healing and blessing and strengthening. ...

The Lord wants every one of His ministers to come into line. Take hold of the medical missionary work, and it will give you access to the people. Their hearts will be touched as you minister to their necessities. ${ }^{3}$

Furthermore, this statement says that ministers are to teach health reform.

Ellen White describes the work that she and Sara McEnterfer, her secretary and nurse, did in Australia, stating, "In Australia we also worked as Christian medical missionaries... No charge was made for her services, and we won the confidence of the people by the interest we manifested in the sick and suffering."

Third, the whole church, each member, is to be engaged in health evangelism, for "we have come to the time when every member of the church

${ }^{1}$ Damsteegt, 238.

${ }^{2}$ J. White, "The Health Reformer," $H R$, December 1873, 372, quoted in Damsteegt, 241.

${ }^{3}$ White, Counsels on Health, 533.

${ }^{4}$ White, Selected Messages, 1:34. 
should take hold of medical missionary work." She does not suggest here that the minister or church members should try to put on themselves the mantle of a physician. However, she is explaining that in the Lord's plan for medical missionary work and health evangelism, there is an active role to play and meaningful place for every member. ${ }^{2}$

Ellen White summed up the outreach aspect of health reform when she told the 1901 General Conference session: "Medical missionary work is the pioneer work. It is to be connected with the gospel ministry. It is the gospel in practice, the gospel practically carried out.",3

It is significant to mention another important development. As time passed, a new channel for spreading the medical evangelism began to function through the self-supporting ministries. In 1904, E. A. Sutherland started a selfsupporting school, which later became known as Madison College. This institution trained future home and overseas missionary teachers. As a result of the work of this college, as many as forty small outpost schools were organized, which were famous for "strong preventive medicine training programs." Today in North America one can find a variety of self-supporting institutions, which differ

\section{${ }^{1}$ White, Testimonies for the Church, 7:62.}

${ }^{2}$ Ellen White speaks about "coming to their homes," "ministering to the sick," "feeding the hungry," "clothing the naked," "comforting the sad," and "tenderly pointing to Christ." "The poor are to be relieved," "the sick cared for," "the sorrowing and bereaved comforted," "the ignorant instructed," "the inexperienced counseled," and so on (White, Ministry of Healing, 140-145).

${ }^{3}$ Ellen G. White, General Conference Bulletin, 3 April 1901, quoted in Robinson, 260.

${ }^{4}$ Williams, Kuzma, and Van Dolson, 254. 
in size, structure, and nature, ${ }^{1}$ but at the same time all of them have one common goal: to spread the health evangelism message as far as possible. Some of the most prominent schools are: Wildwood Sanitarium and Medical Missionary Institute, which was established in 1942, and Weimar Institute, established in $1977 .^{2}$

\section{Adventist Medical Missionary Work in Europe}

Many seem to believe that Ellen White's counsels on health were rather well known among European Adventists during the last quarter of the nineteenth century. However, in spite of the fact that the health endeavor was promoted by some enthusiastic individuals and to some extent by ministers who included the health message in their series of public evangelistic meetings, a great work was still to be done. Whatever progress the health work has experienced, both on the institutional and the personal level, the prime motivating factors have been the writings of Ellen G. White and her personal visits. Responding to an earnest invitation from the brethren at the Second European Council held in Basel, Switzerland, 1884, Ellen White went the following year to Europe and spent two full years laboring in eight countries where major work was in progress. ${ }^{3}$

\section{${ }^{1}$ Ibid., 254-261.}

${ }^{2}$ Jerry Moon, "The Rise of the Self-Supporting Movement in Seventh-day Adventist Education," research paper, Andrews University, May 1988, 44-51.

${ }^{3}$ Ellen White visited England, Switzerland, Denmark, Sweden, Norway, Italy, Germany, and France (D. A. Delafield, Ellen White in Europe [Washington, DC: Review and Herald, 1975], 13-15). 
Health Work in Great Britain

On May 23, 1878, William Ings, "a native of Hampshire, who had lived in America and had worked for the Review and Herald," arrived at Southampton, England, and began Adventist missionary work in that city. Before the end of the year he was able to report ten persons ready for baptism. Other workers who came to England were J. N. Loughborough, Maud Sisley, and in 1882 Adelben A. John and family. ${ }^{2}$

In spite of the fact that the Adventist message was spreading rapidly in Europe, the truth about health gained power only after the personal visit of Ellen G. White. At the beginning of her European tour Ellen White arrived at Liverpool, England, on August 18,1885. Friday evening of that week, August 21, she was scheduled to speak at Grimsby. Delafield points out:

A drenching rain threatened to cut down the attendance considerably, but 170 braved the elements to hear Ellen White's lecture on "Christian Temperance," one of her favorite subjects. At the close of her address she was greeted with enthusiastic applause. ${ }^{3}$

Mrs. White presented her health messages in Ulceby, Risely, London, and Southampton, but her address on Christian Temperance in Grimsby marked the foundation of the health work in the British Isles. ${ }^{4}$ Her approach clearly

${ }^{1}$ SDA Encyclopedia, 1966 ed., s.v. "Great Britain and Northern Ireland."

${ }^{2}$ Ibid., 476-477.

${ }^{3}$ Delafield, 40 .

${ }^{4}$ Ibid. See also Ellsworth Olsen, $A$ History of the Origin and Progress of Seventh-day Adventists (Washington, DC: Review and Herald, 1925), 363-378. 
demonstrated that the health message could be used to introduce and advance the gospel work. ${ }^{1}$

A few years later, in 1900 , the large central tent was always crowded to its limits when Dr. Daniel Kress ${ }^{2}$ gave his public health lectures at Bath. ${ }^{3}$ People came home from that camp meeting inspired and uplifted by the whole gospel message, for Kress never ceased to emphasize the vital relation between the spiritual and physical needs of the human body. ${ }^{4}$ The good work spread, and in a short time Good Health Leagues were formed in almost every church in Great Britain. On the first Tuesday of every month, interested groups of Adventists, with many of their non-Adventist neighbors, came to a chosen meeting place to hear the health discussions and to see the display of treatments in the home. ${ }^{5}$

Another significant person in spreading the health message in the British Isles was Dr. J. H. Kellogg, whose influence on health work was both personal and

${ }^{1}$ One should not forget that this all took place 16 years before her comments at the General Conference in 1901, where she said, "Medical missionary work is the pioneer work. ... It is the gospel in practice, the gospel practically carried out." A. G. Daniels and L. A. Hoopes, "Remarks by Mrs. E. G. White," General Conference Bulletin, 12 April 1901, 203-204.

${ }^{2}$ Before 1887 Kress was a Baptist minister in Michigan. After becoming an SDA and a period of service at the Battle Creek Sanitarium, Kress with his wife Lauretta went to England. For details see SDA Encyclopedia, 675.

${ }^{3}$ Olsen, Origin and Progress, 374, 375.

${ }^{4}$ Gideon David Hagstotz, The Seventh-day Adventists in the British Isles (Lincoln, NE: Union College, 1936), 138.

${ }^{5}$ Ibid. 
indirect. ${ }^{1}$ He visited England several times, and promoted the health reform one way or another. A. B. Owen confirms this:

Vegetarianism in England has distinctly pressed ahead within the last few months. This is mainly due to the visit of Dr. Kellogg, of the Battle Creek (Mich.) Sanitarium, and to the subsequent openings of half a dozen English institutions on the plan of Battle Creek. ${ }^{2}$

The Belfast Sanitarium was a direct result of Kellogg's visit and lectures there. ${ }^{3}$ Treatments were given to resident and non-resident patients using the methods developed at the Battle Creek Sanitarium. Speaking about the sanitarium work, Ellen White pointed out that "this is the only way in which the higher classes can be reached, and I feel highly honored because God had placed among us an instrumentality that could reach the higher classes. ${ }^{, 4}$

\section{Ellen G. White in Switzerland}

A second European country which Mrs. White visited while in Europe was Switzerland. There she held important meetings and took part in the first Swiss Conference. However, one of the brightest episodes in this country was her

${ }^{1}$ Kellogg was an unusual man and an indefatigable promoter of better health through biological living, encouraging vegetarianism, proper exercise, and the avoidance of tobacco, alcohol, and other stimulants. He published nearly 50 books on his views. He condemned the practice of women wearing corsets because they prevented them from breathing naturally. He developed flaked cereals and invented a vibrating chair to increase the circulation of the blood, a vibrating belt to similarly aid circulation and to help weight reduction, and the universal dynamometer, a strength-testing device.

${ }^{2}$ A. B. Owen, "Belfast Sanitarium," The Medical Missionary and Gospel of Health (January 1903): 26.

${ }^{3}$ Ibid., 25-26.

${ }^{4}$ Daniels and Hoopes, 203. 
lecture on the subject of temperance to approximately 200 people in the National Baptist church at Tramelan during the last year of her European tour. For two consecutive hours Ellen White spoke to her audience about health issues, and "there was not one who was asleep or uneasy."1

Visiting Basel on February 17, 1887, Ellen White spoke to a great audience at the next Swiss Conference. ${ }^{2}$ The meetings were assigned to her for the whole weekend. Friday night she preached from John 15:1-8; three sermons on Sabbath were drawn from Daniel, chap. 1; and on Sunday she stressed temperance in the Christian's life. ${ }^{3}$ Remembering these meetings Ellen White wrote:

I never felt more in earnest when addressing a people on the subject of temperance, and we had evidence on this occasion that many hearts were deeply impressed. A request was made for me to speak again on the subject of temperance Sunday evening which I did. There seemed to be no diminishing of the interest. After the discourse Sunday evening, the pledge was circulated, and one hundred and thirty-seven names were attached. ${ }^{4}$

At the same time, some of the Adventists did not want to sign the temperance pledge. They justified their choices of drinking wine at work places for "they could not refuse to take it for fear of offending those for whom they worked." The beer-drinkers had almost the same problem. Mrs. White reacted to this with the following words: "I thought that here was a very good opportunity for

${ }^{1}$ Ellen G. White, Manuscript 29, 1887, quoted in Delafield, 269.

${ }^{2}$ Ellen G. White, "The Conference at Basel," Review and Herald, 19 April $1887,241$.

${ }^{3}$ Delafield, 270.

${ }^{4}$ Ibid.

${ }^{5}$ Ibid. 
them to lift the cross.... We should never be ashamed of temperance in all things."

At that conference Ellen White also brought the test of temperance to the consciences of the people by inviting them "to sign the pledge to abstain from Java coffee and the herb that comes from China." In addition, tracts and pamphlets were translated and distributed. In this way the health message gained a foothold not only in Switzerland but also throughout Europe. ${ }^{3}$

The Temperance Movement in Norway

It is significant to note that, at the time of Ellen White's visit to Norway in 1885 , the question of temperance was very much on the public agenda. The Teetotaler movement ${ }^{4}$ was rapidly gaining momentum, engaging growing numbers of people from all ranks of life. At the forefront of this movement stood Dr. Oscar Nissen, Ellen White's host at the temperance meeting.

On Friday, November 6, 1885, the following announcement was printed in the Aftenposten: "Mrs. E. G. White from California will give a temperance lecture,

\section{${ }^{1}$ Ibid.}

${ }^{2}$ Ibid., 271.

${ }^{3}$ Matilda Erickson Andross, Story of the Advent Message (Washington, DC: Review and Herald, 1926), 221.

${ }^{4}$ The Teetotaler movement had its greatest period of expansion in the 1880s. In 1879 there were about 60 lodges, with a membership of 7,000, but by 1887 , this number had grown to 643 lodges with a total membership of about 83,000 . In 1895 the number of teetotalers in Norway was more than 150,000. They advocated total abstinence from all forms of alcohol. John Matteson founded a health journal, called Sundhedsbladet, in 1881. See Ellen G. White and Europe 1885/1887: Symposium Papers (Bracknell, England: Newbold College, 1987), 193. 
Sunday November 8 , at $5 \mathrm{pm}$ in the Fortress Gymnasium. On behalf of the Board of the Norwegian Teetotalers Society, A. Halvorsen, Secretary."I The military gymnasium at the Akershus fortress was probably the largest available hall in Christiania.

A large crowd of about 1,600 people came to hear Ellen White's lecture. Among them were many prominent citizens, the bishop of Christiania, and a number of the clergy. ${ }^{2}$ Ellen White's lecture lasted for about an hour and twenty minutes. Somewhat to the surprise of her audience Ellen White presented the topic of temperance from a biblical point of view, ${ }^{3}$ showing that the Bible was full of history that was related to this question. ${ }^{4}$ When the lecture got under way, the audience was first astonished, then their interest was raised, and they ended up being deeply moved. ${ }^{5}$

SDA medical work began in Norway in 1898 when two graduates of the Battle Creek Sanitarium, Alma Andersen and her sister, Emma Fleisher, opened a
${ }^{1}$ Karl Abrahamsen, Norsk Bokforlag 100 år (Oslo: n.p., 1979), 28.
${ }^{2}$ Ibid., 190.
${ }^{3}$ Ellen G. White, Historical Sketches of the Foreign Missions of the Seventh-day Adventists (Basle: Imprimerie Polyglotte, 1886), 207-211.

${ }^{4}$ She pointed to Adam and Eve in the Garden of Eden; to Christ who was tempted on the point of appetite; to Nadab and Abihu, whose example was a warning to all who 'minister in holy things,' showing that this applied even to judges, law-givers, and teachers; she pointed to the wife of Manoah and to Zachariah, who served as examples for parents in raising their children; and she reminded the youth of Daniel's example. She also took in the economic side of the question, noting that the means spent on stimulants could better be used to relieve suffering (ibid., 208).

${ }^{5}$ Ibid., 211. 
clinic in Christiania. ${ }^{1}$ In fact, as a consequence of the health message Adventists established several health institutions and health clinics in Norway.

Though to describe the whole story of Adventist medical missionary work which started in America and spread throughout Europe is beyond the scope of the present research, the developments in Switzerland, Great Britain, and Norway are representative of the work in much of Europe, and provide patterns that can be adapted to the situation in Latvia.

${ }^{1} S D A$ Encyclopedia, 1966 ed., s.v. "Norway." 


\section{CHAPTER 6}

\section{A PROGRAM FOR HEALTH EVANGELISM IN LATVIA}

The proclamation of the gospel to the nations of the world is the greatest privilege and responsibility of the Seventh-day Adventist church. For more than 135 years health and evangelism in the Adventist church have been inseparable. According to the Annual Statistic Report, the Seventh-day Adventist church today operates 159 hospitals, 306 clinics, 118 retirement homes and orphanages, three medical schools, and one dental school. ${ }^{1}$

The reason for such emphasis on this type of work is that health constitutes a basic need for every person, hence offers an opportunity for the church to exemplify the character of Christ and display its own raison d'etre by serving individuals at the point of a universal human need. Thus individuals encounter Christ in a practical way and are attracted to Him. Each of the Adventist medical centers listed has contributed to the growth of the church. For example, Giffard

${ }^{1}$ General Conference of Seventh-day Adventists, $135^{\text {th }}$ Annual Statistical Report (Silver Spring, MD: General Conference of SDA, 1997), 7. See also Kim Peckham, "Together Forever," Adventist Review, January 31, 2002, 14-15. 
Memorial Hospital, India, alone contributed in establishing thirty-five churches and companies in keeping with the denominational emphasis. ${ }^{1}$

Furthermore, restoration of health is part of a minister's calling. Ellen G. White in her book Medical Ministry makes a very powerful statement: "Ministers, do not confine your work merely to giving Bible instruction. Do practical work. Seek to restore the sick to health. This is true ministry. Remember that the restoration of the body prepares the way for the restoration of the soul."2

Previous chapters in this study have laid the foundation for designing a program of health evangelism especially for Latvia. This chapter describes such a program, consisting of several attractive and proven suggestions for medical evangelism and consequent church growth in the current Latvian cultural, economical, and religious situation. The program includes three main aspects: (1) churches as training centers, (2) churches' outreach into the communities, and (3) the establishment of medical institutions. Following the description of these approaches, the chapter will also present sections on implementing and evaluating this program of health evangelism.

${ }^{1}$ Measapogu Wilson, “A Health Evangelism Strategy for Reaching Rural Indians with Giffard Memorial Hospital as a Model" (D.Min. dissertation, Andrews University, 1999), 35. The term "company," as used in this context, designates a Seventh-day Adventist congregation in process of formation that has not yet been formally recognized as a "church."

${ }^{2}$ White, Medical Ministry, 240. 


\section{Description of the Program}

Every Church a Training Center

In the book The Ministry of Healing Ellen White presents a clear statement that "every church should be a training school for Christian workers. Its members should be taught ... how best to help the poor and care for the sick, how to work for the unconverted." While the medical centers aim for community-oriented programs, local churches are called to develop local health centers. Ministers and church members should be well prepared by education and practice to fight disease of the body as they are to heal the sin-sick people by pointing them to the Great Physician. $^{2}$ For this purpose pastors and qualified laypeople are called to be ready to teach their church members about their Healer, and that with the healing come special opportunities. These opportunities include utilizing the therapy of the Bible and identifying them with the Wounded Healer. As J. A. Knight says, "The minister and the physician are the two professionals who have managed to keep their charismatic authority."3

Utilization of a church-sponsored short-term health and wholeness education series may be the first step in teaching and equipping church members for service. These series may also be named seminars and be "appropriate forms of

\footnotetext{
${ }^{1}$ White, Ministry of Healing, 149.

${ }^{2}$ Ibid., 238.

${ }^{3}$ J. A. Knight, "The Minister as Healer, the Healer as Minister," Journal of Religion and Health 21 (1982): 100.
} 
motivation"1 for a new type of evangelism. They could be beneficial both for the church members themselves and, most important, for evangelistic purposes of equipped laity. Van Dolson and Spangler pointed out that "in order for the church medical missionary team to work together, they must be trained together."2 All church members who are interested in medical evangelism should be willing to attend seminars that will be carried out by trained professionals. At these seminars people can receive practical guidelines for their own health benefits and would be outfitted for sharing the good news of physical, mental, and spiritual well-being with their surrounding communities.

There may be a variety of proposed seminars on a topic of health evangelism. The main ones, such as Eight Essentials of Health, Hydrotherapy, Cooking School, Stress Management, Prayer Healing Ministry, and some other health promotional programs, may be the best ones for the Latvian society in the beginning of the twenty-first century.

\section{Seminars on the Eight Essentials of Health}

A seminar on the Eight Essentials of Health may be also called Natural Remedies Seminar. These are fundamentals that God gave to Adam and Eve in

${ }^{1}$ Daniel Belvedere, "Motivating Lay Members for Mission," in ReVisioning Adventist Mission in Europe, ed. Erich W. Baumgartner (Berrien Springs, MI: Andrews University, 1998), 184.

${ }^{2}$ Van Dolson and Spangler, 84. 
Eden, which still are available and useful today. Even though the emphasis on natural remedies is well known in the Adventist church, it is still proper to have seminars on the basics of health reform, including pure air, water, proper diet, exercise, rest, sunlight, temperance, and trust in the divine power of God.

In many places in the writings of Ellen G. White, she advises teaching church members the use of the natural remedies. She writes, "Let physicians teach the people that restorative power is not in drugs, but in nature. Disease is an effort of nature to free the system from conditions that result from a violation of the laws of health. In case of sickness, the cause should be ascertained. Unhealthful conditions should be changed, wrong habits corrected. Then nature is to be assisted in her effort to expel impurities and to reestablish right conditions in the system."1

A presentation of such a seminar, however, should not encourage people to use only simple remedies in the place of well-established medical care prescribed by a reputable physician. ${ }^{2}$ It would be a mistake to use only a natural remedy if something more effective is available. Natural eight-steps-to-health remedies are more preventive and church members should be well acquainted with them. By knowing and using them laity would have an effective bridge to the hearts of their friends, relatives, neighbors, and co-workers.

\section{Seminars on Hydrotherapy}

\footnotetext{
${ }^{1}$ White, Ministry of Healing, 127.

${ }^{2}$ Williams, Kuzma, and Van Dolson, 81.
} 
A seminar on hydrotherapy for the church members may also be one of the biggest blessings in the field of reaching others. Latvians ordinarily use a lot of water because of its abundance. Therefore, it is a good reason to acquaint them with the wise and beneficial use of a precious God-given gift for their health. Ellen G. White describes water as "one of Heaven's choicest blessings. Its proper use promotes health."1

This seminar will train church members along with their ministers in the safe use of hydrotherapy and other similar simple remedies. It will teach an ethical approach to giving home treatments, and show their relevance in community outreach.

\section{Cooking Schools}

An important factor to remember in conducting health evangelism is that health is a sensitive area for most people. It should be approached quite "diplomatically and cautiously." 2 The Adventist church teaches a lot about proper diet and its benefits for human physical health. One of the best, most practical ways to implement a correct diet is to teach the principles of proper cooking, first to church members and then to others.

Cooking school classes may provide good service for churches and surrounding communities, which struggle with unemployment, financial burdens, and unforeseen social changes. Successfully organized cooking schools could help

\footnotetext{
${ }^{1}$ White, Counsels on Diet and Foods, 419. See also idem, Medical Ministry, 228.

${ }^{2}$ Van Dolson and Spangler, 169.
} 
people to learn to survive in the given circumstances by preparing more qualitative food with less expense. This line of work is as essential as any that can be taken up. "More cooking schools should be established, and some should labor from house to house, giving instruction in the art of cooking wholesome foods. Many, many will be rescued from physical, mental, and moral degeneracy through the influence of health reform."1

A cooking school held in a church or in any other appropriate place may be very beneficial. People not only learn how to prepare the right food, but most important, they would spend time with each other personally. This is an opportunity for church members to share their faith with others. ${ }^{2}$

\section{Seminars on Stress Management}

As was described in chapter 2, Latvians live today in a very hectic time. They face challenges of everyday life without finding any answers to them. Adventist church members are also going through the same life tests. Therefore, the Adventist church has an awesome opportunity to minister, to be a tool in God's hands. People who are subjected to any kind of stress or emotional needs may have an unmet need for spiritual stability. At the same time people may not understand their real needs or may be reluctant to admit that they have problems because many believe that having problems is $\sin$.

\footnotetext{
${ }^{1}$ Ellen G. White, Welfare Ministry (Washington, DC: Review and Herald, 1952), 128.

${ }^{2}$ Williams, Kuzma, and Van Dolson, 110.
} 
A seminar on stress management may first help the parishioners to discover their own problems and to get acquainted with the Healer and Counselor. ${ }^{1}$ When someone is mentally or physically healed by Christ through the power of the Holy Spirit, it is one of the strongest testimonies in behalf of God's restoring power. Then church members may also become instruments of spreading the good news to their neighbors that it is possible to live amid troubles without being in trouble.

\section{Prayer Healing Ministry}

Medical evangelism includes a very special and often neglected part, which is prayer ministry. The apostle James directed, "Pray for each other so that you may be healed" (Jas 5:16). "Spiritual healing in general, and prayer for the healing of the physically and mentally ill in particular, has been largely neglected in the western Adventist church and the dominant medical community. The church should make it a high priority to articulate a theology of healing prayer and to institute the practice of such prayer as a vital, integral part of our ministry to those in need."2

In the light given to the church from the Bible and the writings of Ellen White, it is evident that Adventists should be doing more in prayer ministry for the

\footnotetext{
${ }^{1}$ Isa 9:6. Even though Jesus is the best Counselor, "the Lord can do nothing toward the recovery of man until, convicted of his own weakness, and stripped of all self-sufficiency, he yields himself to the control of God. ... From the soul that feels his need, nothing is withheld. He has unrestricted access to Him in whom all fullness dwells" (White, Desire of Ages, 300).

${ }^{2}$ Jon Dybdahl, "Faith and Healing," in Health 2000 and Beyond, ed. Stoy Proctor (Silver Spring, MD: General Conference of Seventh-day Adventists, 1994), 203.
} 
sick. Such prayer ministry is to be combined with the use of the simple remedies the Lord has given to His children. "God is more anxious to show Himself than we have ever believed, and we need to allow Him to act."1

Even though Ellen White specifically warns against going to extremes and fanaticism in this type of ministry, ${ }^{2}$ healing through prayer and natural remedies represents one branch of last-day medical evangelism that needs to be implemented much more than it has been. Therefore church members should be properly instructed concerning prayer ministry for the sick.

\section{Other Health Promotional Actions}

A seminar, small-group activity, or any church gathering may be organized in such a way that people will understand the urgency and advantage of using medical evangelism to finish the task of proclaiming the gospel. Such activities may promote the necessity for personal practice of health principles and the importance of training the members in the promotion of medical missionary outreach programs.

Once church members become convicted that healthy habits strengthen their own immune system, giving them added protection against modern lifestyle diseases, they should be ready to make some personal lifestyle changes, experience the benefits, and then share what they have learned with the community. ${ }^{3}$

${ }^{1}$ Ibid., 209.

${ }^{2}$ White, Welfare Ministry, 81.

${ }^{3}$ Williams, Kuzma and Van Dolson, 61-62. 
The Church's Public Outreach

Instruction from the Holy Scriptures is clear that caring for the sick is very much a part of the mission of the church (Matt 4:23-25), therefore, the proclamation of the message of Christ's soon return is to be based on His missionary example.

The challenge today in Latvia is to involve health promotion in the soulwinning process of the church in such a way that there may be real fruit for eternity. "Medical missionary work is the right hand of the gospel," states E. G. White.

A church is a basic part of the community and plays an important role in community health. It can serve as a center of health education and service, utilizing a variety of resources and materials, in order to meet community needs. When well trained for evangelism, church members, especially nurses and medical doctors, may be effective leaders in organizing church-sponsored programs and seminars for a local community. Health promotion programs will vary, depending on the needs of the specific neighborhood. The following suggested programs may furnish a starting point for an ever-expanding community health ministry. For example, a Home Health Care seminar will prepare the interested ones to care for the physically weak and elderly. Family Health, Family Nutrition, and Family Life seminars will focus on main principles of developing and preserving physical, mental, and spiritual unity and health within a marriage bond. A Stress

\footnotetext{
${ }^{1}$ White, Counsels on Health, 34.

${ }^{2}$ White, Testimonies for the Church, 7:59.
} 
Management seminar will equip a community with the tools that would lead to inner mental and spiritual balance and help to preserve it in critical situations. Smoking Cessation, Overcoming Alcoholism, and other related workshops will teach people to combat various forms of addictions, which are so vide spread today in the Latvian society.

\section{Health Food Restaurants}

In large Latvian cities, such as Riga, Liepaja, Daugavpils, Valmiera, and others, health food restaurants might provide significant help to evangelistic work, with or without the help of the Latvian conference. Such restaurants may become one of "a variety of entry points through which people may enter" the Christian community. Restaurants may not only promote right cooking schools for the community they serve, but also be places where people would gather for Bible classes and some other related activities.

Such restaurants could also become an entering wedge to the poorest part of the Latvian population. Health food restaurants could devote an hour per day to feeding materially and spiritually needy people from a neighborhood. Thus the poor may also be drawn to the proclamation of the Adventist Message. ${ }^{2}$

${ }^{1}$ George Barna, Evangelism That Works (Ventura, CA: Regal, 1995), 135.

${ }^{2}$ Matt 25:34-40. See also Ellen G. White, My Life Today (Washington, DC: Review and Herald, 1952), 241. 


\section{Evangelistic Campaigns and Health Promotion}

Even though evangelistic campaigns in Latvia are no longer as successful as they were in the first part of the 1990s, they are still in use and bringing souls to Christ. At this point pastors and evangelists should remember the spiritual, emotional, and physical unity that God wants to see in His children. "The gospel ministry is needed to give permanence and stability to the medical missionary work; and the ministry needs the medical work to demonstrate the practical working of the gospel. Neither part of the work is complete without the other."1 Therefore, it is good for a doctor or a nurse to have twenty to thirty minutes every evening during an evangelistic campaign to share health promotional materials with the audience.

\section{Medical Institutions}

There are many different ways to promote health evangelism within the church, and by the church in its community. At the same time, a more advanced step in health promotion in Latvia should not be overlooked. Even though it may be difficult today to imagine having an Adventist health institution in the country, it is a very real possibility and privilege to have one. With much prayer and faith of the church members, God may open the doors of opportunity.

\section{Medical or Dental Clinic}

Because Riga is the biggest and the most diverse city in the country it would be the best place to begin institutionalizing a Latvian Adventist health

\footnotetext{
${ }^{1}$ White, Counsels on Health, 514.
} 
network. With a group of devoted-to-God medical doctor(s), dentist(s), and nurses a small medical or dental clinic may be opened. It could both serve a local community and be a strong witness for God. While treating patients, the staff will look for opportunities to talk to them about spiritual values, lifestyle changes, and the purpose of God in creating man in His image. Such an approach will encourage patients to think about spiritual things and create a desire to know more. $^{1}$

The purpose of such a medical or dental clinic is twofold and will reach its best achievements and prosperity only as workers realize that they are involved in a very noble work for the Lord.

Then, following the example of Riga's clinic, similar institutions could be established in different parts of the country, paying attention to the specific needs of a local community and the availability of staff personal.

\section{Nursing Home}

There is an urgent need in Latvia of establishing an Adventist nursing home for elderly people. Many Adventist church members are taking care of their aged brothers and sisters in Christ without any compensation; nevertheless, they have their own families and duties. At the same time, there are in every community many elderly people who live alone with little outside help.

The church has a unique privilege to serve elderly people in need. Providing their physical essentials would open a great opportunity to serve their emotional and spiritual needs.

\footnotetext{
${ }^{1}$ Wilson, 167.
} 


\section{Self-Supporting Health Ministries}

Based on the commands of Jesus, ${ }^{1}$ all church members should be active medical missionaries. Yet, it is impossible for the Latvian church to hire everyone. Some may find work as medical evangelists on a self-supporting basis. They will have the freedom to plan their work according to their own understanding of the Bible and the writings of Ellen G. White. ${ }^{2}$ Most medical selfsupporting institutions usually are experienced with natural remedies. Because drugs are not very effective for treating influenza, colds, coughs, and simple afflictions, self-supporting institutions view a plant-based diet, exercise, and hydrotherapy as important remedies. These institutions specialize in prevention. ${ }^{3}$

Self-supporting institutions may be very beneficial for Latvia today. The staff of such an institution may not only bless their local community, but also visit neighboring churches to teach members how to cook healthy food and train them to use simple remedies for the prevention and treatment of common diseases.

The purpose of self-supporting health work, a nursing home, and a medical or dental clinic would be to promote the restoration of physical, mental, emotional, and spiritual health in Latvian society by leading people to their personal Healer and Savior.

\footnotetext{
${ }^{1}$ Mark 16:15; Matt 10:18; 28:19.

${ }^{2}$ Williams, Kuzma, and Van Dolson, 253.

${ }^{3}$ Ibid., 254.
} 


\section{Implementation of the Program}

Implementation of the proposed program would begin in the Adventist church. A spokesperson or a director of Health and Temperance Department from the Trans-European Division or some worldwide well-known guest speaker(s) from the General Conference of the Seventh-day Adventist church will be invited to hold a seminar in order to train pastors and Health Department leaders from all the Latvian churches. Subsequently, well-prepared pastors ${ }^{1}$ with church representatives would promote health evangelism seminars within their local churches, equipping local church members all across the country, and they in turn would spread the good news further in surrounding communities.

It is not enough with a one-time seminar, led by an experienced speaker. The various leaders will meet periodically in order to gain new insights and share together their experiences, as every church has its own unique setting and challenges and what works for one environment does not work for another. Ideally the number of the interested church members in health evangelism should grow. It means they should be trained for this task. Therefore, during monthly pastoral meetings in Riga, the local experts or any other qualified person will continue the work started by the guest speaker by presenting various aspects of medical evangelism. These presentations would involve the main issues

${ }^{16}$ The place of the pastor in the evangelism of the local church is strategic. If he is evangelistic, the church will ordinarily be evangelistic. The degree to which the pastor is evangelistic will be reflected in the church. If he is lukewarm, the church will very likely be lukewarm. If he is intensely evangelistic, the church will reflect the warmth and concern of the pastor" (C. E. Autrey, Basic Evangelism [Grand Rapids, MI: Zondervan, 1954], 63). 
concerning the essence, implementation, instructions, and progress of the health program. They will be followed by a discussion and a prayer session, because it is vitally important for its participants to understand that "the fundamental reason for the church's impotence is her ignorance of the power of Christ", and that "the burden for success rests on the Holy Spirit. Primary challenge to the believer is to follow God's leading."

The purpose of such meetings is not only to train and convince the various church leaders of the urgent need to use current evangelistic opportunities wisely, but also to inspire them. The highly motivated pastors and lay leaders are responsible for equipping the people under their charge for this vital task. Therefore, they will receive all the necessary information and textbook materials for the work with their interested church members. Preliminary syllabuses for the laity involved in health evangelism will be prepared in both Russian and Latvian languages by the literature department of the Latvian Conference. These materials will contain the instructions for conducting cooking schools and the following four seminars: Eight Essentials of Health, Hydrotherapy, Stress Management, and Prayer Healing Ministry. There could also be used audio-visual materials and transparencies, which may be purchased through the Adventist Book Centers and translated or otherwise adapted to the specific needs of the local community.

Preparation for the church outreach activities should be planned and coordinated at all possible levels. The proper time, place, and availability of

\footnotetext{
${ }^{1}$ Emil Brunner, The Mediator (London: Lutterworth, 1962), 14.

${ }^{2}$ Barna, Evangelism That Works, 75.
} 
finances play important roles in the realization of the program. Therefore, the local church proposals of any designed outreach activity should be presented before the Latvian Conference committee. Interested people, preferably specialists in a given field, should be invited to conduct seminars for the unchurched and especially to give health-related talks before the evangelistic campaign.

Before the implementing of medical institutions in Latvia there should be formed an executive committee, which will work as a mediator between the church and the government. ${ }^{1}$ This executive committee will take upon itself the whole responsibility of carrying out the project.

\section{Implementation of the Church Training Seminars}

Church training seminars are the first step in the development of health evangelism in Latvia. The representatives from a local church, who took part in the seminars presented on the Conference level, will be responsible for choosing a core leaders' team to train interested church members. Devoted-to-God doctors, nurses, and other members with specialized skills would be the best to be chosen for the task.

Each seminar should be presented at the best time of a year. The needs of farmers and gardeners, ${ }^{2}$ the early darkness and cold winters, and the long summer

'The SDA Latvian church cannot provide the whole financing of a nursing home alone at the time being, therefore some funding might be sponsored by the government or other channels. The executive committee is also responsible for obtaining and securing the license to ensure the opening and functioning of medical institutions.

${ }^{2}$ Almost half of Latvian city-dwellers have gardens where they grow the necessary food products. 
workdays should all be taken into consideration. The best time to present a seminar in the church or outside of it may be in the early spring or late fall seasons, ${ }^{1}$ although a prayer health ministry seminar may be presented at any time of a year. Spring may be the best for hydrotherapy, summer and fall for cooking schools, and late fall for stress management seminars.

Because every community and church has its own individuality and uniqueness, this program for health evangelism in Latvia will give only the main guiding principles and strategies. Step-by-step curricula should be designed at each particular place.

\section{Prayer Healing Ministry}

Regarding prayer ministry, Peter Wagner writes the following, "All Christians must fulfill their role as intercessor, but some have a gift and ministry far above the ordinary."2 Therefore, this seminar is to find out the more gifted people who can intercede for healing the sick $^{3}$ and teach other intercessors the proper use of their gift. A prayer healing ministry seminar will take only two days--on a Friday evening and the following Sabbath afternoon. The power of it depends not on the length of time spent together, but on how well participants

${ }^{1}$ Even during early springtime farmers and gardeners have a lot of work, but the sunshine and length of daylight give people energy. Late fall is a time when all work in the fields is done and people are glad for the blessings of the harvest.

${ }^{2}$ C. Peter Wagner, Prayer Shield (Ventura, CA: Regal, 1992), 52.

${ }^{3}$ There are many different kinds of questionnaires to discover one's giftedness. The following one may be very helpful: Paul R. Ford, Discovering Your Ministry Identity (USA: ChurchSmart, 1998). 
learn to discover "our faith and His will." In teaching people how to pray for the sick it should be remembered that "yet, not my will but yours be done" (Luke $22: 42){ }^{2}$. In the light of the Bible there also should be discussed such important factors as extremism, fanaticism, and spiritualism. Therefore, this seminar may be presented several times during a year for different types of small groups in a church.

\section{Seminars on Stress Management}

Stress management seminars are vitally important and should be held in the late fall. Days are shorter and people feel more depressed than at any other time of a year. During three days pastors themselves or health professionals may introduce to groups of interested church members the essentials of stress management. One of the best and simplest source books for use during a stress seminar may be Managing Stress by the Power of God's Love. ${ }^{3}$ The book contains many illustrations and exercises. It is based on Scripture and the laws of health. There should be no problem in translating the book into the Latvian and Russian languages.

${ }^{1}$ White, Testimonies for the Church, 6:149.

${ }^{2}$ The consistent course of prayer healing ministry is to educate lay people to commit the desires of healing the sick person to the all-wise heavenly Father, and then, in perfect confidence, trust all to Him.

${ }^{3}$ Walter C. Thompson, Managing Stress by the Power of God's Love (Siloam Springs, AR: Creation Enterprises International, 1991). Another good tool for this seminar could be the instructor's manual and workbook written by Skip MacCarty, Stress: Beyond Coping (Berrien Springs, MI: The Author, 1997). 
The following topics may be suggested for presentation during the seminar:

(1) Getting acquainted with stress; (2) Anatomy and physiology of stress; (3)

Learning projects and exercises; (4) Stress solutions; (5) Managing God's temple; and (6) Problem solving.

The participants should have on hand the syllabus of the seminar and a bibliography of easily accessible local and foreign books on the topic. At the end of the seminar, people should be prepared to share with family members, friends, co-workers, and neighbors the practical information they received.

\section{Cooking Schools}

Pastors' spouses can help with the organization of cooking schools. Dieticians, cooks, and housewives can also lend a hand during the preparation and implementation of schools. Vegetarian, healthy, local cookbooks should be available during and after the first seminar. People will learn easier and faster how to prepare healthy and tasty food when there is abundance of fresh vegetables, nuts, and fruits. Therefore, the best time of year for conducting cooking schools is summer and fall. The time of the week to hold a cooking school may vary according to local community circumstances. It could be given on a Sunday afternoon or on any weekday evening for two-three hours per session.

Nutrition videos and practical preparation of food require a fully equipped kitchen and a room with tables and chairs where people can comfortably take notes and taste the prepared food. Cooking schools may also be a time to promote later classes on weight control, gourmet cooking, low-budget cooking, cooking to prevent cancer, one-dish meals, sugarless desserts, and so on. 
The staff's appearance, music, and flowers should indicate quality.

Different speakers should present their lectures during the class. The seminar may be repeated every year with some different variations.

\section{Seminars on Hydrotherapy}

A hydrotherapy seminar includes the promotion of prevention and natural water cures. It requires adequate space and the availability of adequate hot and cold water. Because the Latvian Conference does not yet have a clinic, this seminar could be presented theoretically, with a lot of visual illustrations, transparencies, and videos, with people asked to do their water labs at their homes. The presenters of lectures should distribute material for people to take home. ${ }^{1}$ Books on hydrotherapy should be available for sale. Questionnaires and small quizzes may lend variety to the seminar.

In spite of the unsuitable conditions for teaching hydrotherapy, this seminar may bring a blessing to Latvian pastors, their families, church members, and the Latvian community. People would be eager to learn the proper use, potential qualities, and curative powers of water. They will temper their immune system for winter by using familiar methods of prevention and cure from colds and other diseases.

${ }^{1}$ There is a suggested syllabus by Charles Thomas, G. Damsteegt, and L. Enachescu, Source Book for the Workshop in Hydrotherapy and Home Remedies (Berrien Springs, MI: Andrews University Theological Seminary, 1998). 


\section{Seminars on the Eight Essentials of Health}

Seminars for equipping lay people in the God-given essentials of health should be especially promoted in those churches where they have not been yet fully implemented. A local pastor will organize a core team, including at least one with a medical specialist who would take the responsibility of supervising the advertisement for and conducting the seminar. Well-prepared lectures with visual material and syllabuses on hand will help church members to make positive changes in their own habits. A cooking school and a seminar on hydrotherapy may follow the seminar on Eight Essentials of Health.

Implementation of the above-mentioned seminars and other similar ones will equip church members for radical changes not only in obtaining personal health benefits, but also in improving the health of surrounding communities by their personal examples, testimonies, and practical training.

Implementation of the Church's Public Outreach Activities

Well-prepared church members would go beyond the church borders with a mission to evangelize the non-churched. They can make "an enormous contribution to healthcare." Under the leadership of professionals, lay members can give lectures on a variety of health topics in neighboring schools, libraries, and public clubs. Attractive and colorful advertisements in local newspapers,

${ }^{1}$ Gerald A. Arbuckle, Healthcare Ministry (Collegeville, MN: Liturgical, 2000), 78. 
distribution of eye-catching brochures, and promotion on radio and TV will draw many interested people to hear the given topic. ${ }^{1}$

\section{Health Food Restaurants}

Implementation of health food restaurants may start from a small beginning. In the crowded center of Riga or another big Latvian city, people dedicated to this task, with the help of the Latvian Conference, could rent or buy an apartment for establishing a health food restaurant. In the beginning the church might need to finance its promotion, acquisition of equipment, and staff salaries. With the gain of popularity and income such a restaurant might bring many people to Christ, and also bring in money for further church-sponsored evangelistic programs.

Staff members of restaurants should remember that they are first of all ministers of God, involved in a noble work for the Lord. Their daily task consists not only of feeding physically hungry people, but most important to provide a chance for these people to find their Savior and Friend. Both the environment and the menu should reflect Adventist standards and principles.

${ }^{1}$ As a result of the past years spent under the cruel pressure of communism and totally distorted information by atheism in regard to the church's life and its nature, some people "who are not yet Christians view the church as arrogant, uncaring, and irrelevant" (Elmer Towns and Warren Bird, Into the Future [Grand Rapids, MI: Fleming H. Revell, 2000], 122). If the church wants to rebuff these false assumptions and teachings, today is the time for her to be actively involved in serving all the segments of the population in its community and to demonstrate before the people its true loving and caring nature. 
Such restaurants ought to become health education centers, ${ }^{1}$ where people could learn about the advantages of a healthful lifestyle. During evening hours, groups of interested men and women would gather there for a cup of herb tea and a Bible class or some other Christ-centered activity. By these means, hungry souls would find their wholistic restoration in Jesus Christ.

\section{Evangelistic Campaigns and Health Promotion}

There is also another way through which Latvian churches can reach the nonbelievers. Health advertising talks before the beginning of every evangelistic session would enrich the campaign and attract more people. ${ }^{2}$ There might be health support stands with colorful illustrations, a nurse checking blood pressure and pulse, a table with health promotion books for sale, a lending library, etc. A speaker might present a lecture every night on any health topic, including Smoking Cessation, Drug Prevention, and others. Audio-visual technology with slides or a film would be helpful in presenting a topic.

It must be understood that the suggested lectures and the given health promotion package are only recommendations. Every evangelistic team must be free to employ the programs that are best suited to the needs of the community.

${ }^{1}$ For additional information on health education centers see Williams, Kuzma, and Van Dolson, 207-215.

2"Medical missionaries and workers in the gospel ministry are to be bound together by indissoluble ties. Their work is to be done with freshness and power. By their combined efforts the world is to be prepared for the second advent of Christ." White, Counsels to Parents, Teachers, and Students, 468. 
In the above-mentioned programs and other similar ones, excellence and creativity should demonstrate the spirit of the living God's church, which is eager to minister in the changing and demanding Latvian society. Applied in practice, the above-proposed material will awake evangelism resulting in church members being better motivated ${ }^{1}$ and trained to participate in evangelistic activities. This will also result in "better attendance of non-Christians at evangelistic crusades.",

\section{Establishing Medical Institutions}

Establishing church-sponsored or self-supporting medical institutions is the most complicated step in the development of medical evangelism in Latvia today. Implementation of this advanced point will need to be the subject of much prayer and careful consideration, both from the local churches and from the leadership of the Latvian Conference. It is not recommended that such a large institution as a hospital be owned by the Latvian Conference. Nor is it financially feasible to maintain it. A small clinic, however, owned and operated by the Conference, could be an effective means of health ministry.

\section{Medical or Dental Clinic}

The purpose of medical institutions is to reach people with the message of health in preparation for God's kingdom. Therefore, a medical or dental clinic

\footnotetext{
${ }^{1}$ "Healthy churches do not pay staff to do ministry. They equip the laity to do ministry. Staff does not replace volunteers. Staff identify laity for ministry, recruit and deploy laity into ministry, and equip laity for ministry" (William Easum, The Complete Ministry Audit: How to Measure 20 Principles for Growth [Nashville: Abingdon, 1996], 32).

${ }^{2}$ Cameron, Evangelism in Today's World, 137.
} 
might be the best choice for a beginning. At the outset a facility could be bought or rented depending on specific local circumstances. A doctor or dentist and a nurse might be a good team for the establishment. With growth and availability of additional persons, the staff might be doubled.

A clinic should have a table with Adventist health promotion books and Bibles available to read in the waiting room. Colorful pamphlets in Latvian and Russian languages with biblical texts, health-related information, and addresses of nearby Adventist churches should be available for people to take with them. Medical staff should be instructed to give an answer to any elementary biblical question. ${ }^{1}$ There should also be an emphasis on prayer and personal commitment to God and His leading ministry.

\section{Nursing Home}

A gradual transition from home-based care of elderly persons to an institution where more than one patient would live together under the care and support of professional personnel might be the best suggestion for Latvia today. Acquisition of a license and a house should be prioritized. Because of the lack of sufficient financial support from the Conference, in the beginning a nursing home might share space with a clinic or vice versa.

${ }^{1}$ Because it is impossible to keep a chaplain in a clinic (even if it were possible to have a chaplain), the medical staff is called to reflect Jesus in their work by pointing people's attention to God as the source of all wisdom, health, and life. This is true not only because of a lack of chaplains, but because in most cases people have higher respect and admiration for the medical staff than for the chaplains. Consequently, if the medical staff speaks of Jesus, it has a more powerful influence. 
A second step in establishing a SDA nursing home in Latvia might be staffing and equipping it. Three or four aides, a nurse, and preferably a visiting doctor from a clinic and a chaplain-pastor from a nearby church would make a good caring team. Staff people should be trained in both evangelism and health work. Material for training and the process itself should be under the leadership of a chaplain-pastor and a doctor.

In the beginning there should not be excessive concern for buying new beds, wardrobes, tables, chairs, kitchen equipment, etc. Elderly people may bring their own furniture with them. Donations from supporting organizations and people would be better spent for the acquisition of medical needs. ${ }^{1}$ Patients' government pensions would cover expenses for food, lodging, and personal needs. Staff people should be paid by the Latvian Conference.

\section{Self-Supporting Health Ministries}

In regard to the implementation of a self-supporting health work in Latvia, it is difficult to give much detail because this type of work is flexible and may vary. Evangelistically equipped lay people may use their talents and money in different ways to spread the gospel. Some of them, who have medical education,

${ }^{1}$ The executive committee, together with the help of the nursing home staff and the SDA church members, should seek all possible ways of getting sponsorship for the project. Help should be sought from community services, firms, big companies, government, and from abroad. 
might be willing to open local medical clinics, and even something bigger, such as a sanatarium ${ }^{1}$ or health education centers.

In order not to go to extremes, the founders of a self-supporting health ministry need to be instructed about the history and modern productivity ${ }^{2}$ of Adventist self-supporting health institutions. Each institution should have its own goals and mission statement. Such an institution may offer to a community a variety of health education programs, live-in lifestyle programs, training programs, camp meetings, publications, and other resources to meet health needs throughout lifestyle changes. Despite the fact that a self-supporting health ministry will not be sponsored financially by the Latvian Conference, the Conference and lay ministry still may labor for Christ as one team, having one common purpose.

\section{Evaluation of the Program}

Health evangelism, as a specific aspect of evangelism, is a very broad notion. It includes a variety of diverse programs in or by a church, and of establishment and procedure-varied medical institutions, such as clinics, sanatariums, hospitals, and even universities. Every program is subjected to evaluation and alteration with changes of time, events, politics, financial support,

${ }^{1}$ Any spot outside the cities along the sea might be the ideal place to locate a sanatarium or other health education center. The favorable climate, the temperate seawater, the sandy beach, and the fragrant zone of pines may be the place Ellen G. White suggested for locating a sanatarium. See White, Counsels on Health, 266. See also Pelekais etal., 9.

${ }^{2}$ See Williams, Kuzma, and Van Dolson, 253-261. 
and technology. Nothing is the same today as it was yesterday, except the eternal gospel of Christ.

The proposed and to be implemented health evangelism program in Latvia should also be evaluated according to specific local circumstances. In order to function and prosper, each part of the program should be reviewed, questioned, and, if necessary, changed, at least every half a year for the first three years. After that, if the work goes smoothly with sufficient funds and evident results, evaluation may be prolonged from every six months to every twelve months.

Local church boards with the pastor as a leader would be responsible for the evaluation of their church training programs. They may organize an evaluation committee, which will examine and analyze each seminar. The committee may ask the following questions: (1) Does this seminar bring positive changes in the lives of the participants? (2) Are the church members more evangelistically oriented after a seminar? (3) Do these seminars reveal lay members' giftedness and do they promote usage of their gifts? (4) How may the seminars and programs on health topics be improved and what kinds of new ones may be introduced? Asking these and other similar questions will help to evaluate the equipping of laity for health evangelism and provide better work for greater impact in the future.

To evaluate a church's public outreach programs, the Latvian Conference could organize at least four district committees. ${ }^{1}$ Each committee would have at

\footnotetext{
${ }^{1}$ Latvia has four "ethnic parts: Vidzeme, Kurzeme, Zemgale, and Latgale." See Pelēkais et al., 8.
} 
least three members: a pastor, an evangelist, and a lay member. These committees will critique the work done. The subsequent questions may be asked: (1) What has been accomplished by the church's public outreach? (2) How have health-oriented workshops contributed to evangelistic series attendance and baptism? (3) Is a health food restaurant mission-oriented? (4) What is the financial status of such a restaurant?

After critical evaluation and analysis, improvements can be recommended. If there is a need, the committee may introduce the work of a church's public outreach to the board of the Latvian conference for discussion and recommendations. Also if it is necessary to close a restaurant because of financial constrains, a lack of missionary spirit, or other weighty reasons, it should be done without procrastination.

In order to evaluate the work of medical institutions the Latvian Conference should form a special committee. The members of it might be the same as the members of the executive committee including also a representative from the staff of the institutions. This working group would be responsible to check and evaluate the progress of church-sponsored clinics and nursing home, to see that they are not only surviving, but growing in all dimensions.

The evaluating committee will deal with the following and similar ones questions: (1) What is the spiritual status of the institution? (2) What is the financial situation there? (3) Are the clients satisfied with the service provided? (4) Is the medical staff adequately equipped? (5) What kinds of improvements could be done? In regard to self-supporting health-oriented institutions in Latvia, they 
would need to provide their own similar evaluation in order to find out their weak and strong points. If they would desire to invite some members from the conference or from the conference evaluating committee, help should be provided.

Evaluation is the last and vitally important part of implementing and maintaining a health evangelistic program in Latvia. Every little step of the program should be tested and proved to be workable. Moreover, Ellen G. White clearly points out that "the Lord tests our ability by first giving us small duties to perform. If we turn from these with dissatisfaction and murmuring, no more will be entrusted to us until we cheerfully take hold of these small duties and do them well; then greater responsibilities will be committed to us." By evaluating the work which is done, humans are also evaluating themselves. "Thus we are to serve God.... All who would be sons and daughters of God must prove themselves co-workers with God and Christ and the heavenly angels. This is the test for every soul. Of those who faithfully serve Him the Lord says, 'They shall be Mine, . . . in that day when I make up My jewels; and I will spare them, as a man spareth his own son that serveth him.' Mal. 3:17.,2

${ }^{1}$ White, Testimonies, 2:249.

${ }^{2}$ Ellen G. White, Christ Object Lessons (Washington, DC: Review and Herald, 1941), 283. 


\section{CHAPTER 7}

\section{SUMMARY, CONCLUSIONS, AND RECOMMENDATIONS}

This last chapter summarizes the previous chapters of the dissertation, lists conclusions drawn from the research, and, finally, presents recommendations for implementation of health evangelism in Latvia.

\section{Summary}

Having explored the whole texture of Latvian culture and society, it becomes evident that the people have suffered not only during the process of various political, social, and economic upheavals, but also from the consequences these changes have brought. The result is a multinational community, of which the majority speak the Latvian and Russian languages. The society that recently was under the rule of communism has regained freedom and full independence. Nevertheless, it continues to struggle against such negative factors as a declining population and a growing rate of unemployment with all its side effects.

Adjustment to the new political and economic system also has left its impact on public health. The increased number of sick children, smokers, people suffering from heart diseases, tuberculosis, HIV, AIDS, stress-related sicknesses, and other maladies make it urgent to broaden and advance a multifaceted health promotional work, which is allowed and can be done in a variety of opportunities. 
Latvian welfare institutions try to perform their duties as well as possible. However, there are still many people who cannot afford medical care. The worst situation is seen with the elderly population. Retirement homes with very limited funds cannot accommodate every needy person.

Regarding religion, Latvia is a Christian country that has gone through several stages of being very pious before World War II, atheistic during the Soviet occupation, and multi-religious in recent years. Lutheranism, as the state religion, shares faith with Catholics, Orthodox, Old Believers, Baptists, Adventists, Methodists, and other Christian denominations. There are also Jews, Jehovah's Witnesses, Muslims, and newer (to Latvia) religions such as Buddhists, Hare Krishna, and Mormons. In addition, Dievturiba, an ancient Latvian religion, has been revived and is spreading rapidly among the population.

The third chapter outlines the progress of Adventist evangelism in the country from its beginnings in 1895 , till World War II. In spite of some obstacles, the church grew rapidly. Adventists printed their own literature and sold it all over the country, even in the neighboring countries of Estonia and Lithuania. Suži Mission Seminary served for seventeen years as the school for literature evangelists, pastors, missionaries, and church evangelists. Active Adventist youth and alumni of the seminary used to lead Bible groups and evangelistic meetings, thus proclaiming the gospel to large groups of people.

The second period for the Adventist church in Latvia, 1941-1991, was the time of Soviet occupation. Though oppressed by communism, the church stood firmly in doctrines, and was united as one family. In spite of the fact that 
evangelism was forbidden, from time to time Adventists had baptisms. During those fifty years the church did not experience growth in membership, but neither did it die. The last decade of that period even prepared the soil for the future evangelistic harvest.

With the restored independence of Latvia came the freedom to again evangelize the country. Since 1991, Adventists have proclaimed the Word of God through Bible classes, prison ministry, literature evangelism, radio broadcasting, and other evangelistic means.

During 1991-1995, the church membership almost doubled. But during the following five years, membership reached a plateau stage with a small decline. This suggests a need to re-examine the methods and philosophy of evangelism.

Chapter 4 established a biblical foundation for wholistic health ministry in Latvia. The eight fundamental principles of health and a happy life had their beginning in the Creation week: fresh air, sunlight, pure water, exercise, proper diet, periodic rest, temperance, and trust in God. God Himself was the Originator of these principles.

Throughout the OT, God was always interested in the well-being of His earthly children, and in spite of their rebellion He still wanted to be their spiritual, mental, and physical Restorer. The most prevalent concept of healing in the Old Testament is healing straight from God (Ps 30:8-12). Scripture also mentions "natural healing" (Deut 33:24) and describes "preventive healing." The latter, as represented in the Mosaic code, is one of the greatest benefits for society. 
The NT presupposes the OT concept of health and accepts its expression in terms of wholeness, obedience, righteousness, and life. A close examination of many references of healing reveals that Jesus was actively involved in the healing ministry. He healed people from many different diseases: fever (John 4:52), wounds (Luke 22:30), blindness (Matt 9:27), skin diseases (Luke 17:20), and many others.

Christ commissioned His disciples to do the work He did. The content of this mission charge consisted of seven imperatives, one of which was to "heal the sick" (Mark 6:8). In other words, the disciples were called to do medicalmissionary work to advance the gospel. It is significant that the apostles, following Christ's example, used not only a healing ministry, but also taught prevention of disease.

This chapter tells that the Bible contains a firm and basic foundation regarding the wholistic health ministry that could be valuable for Seventh-day Adventist health evangelism in Latvia.

The fifth chapter traces the historical developments of Adventist health evangelism in North America and Europe. In the early Adventist movement, Joseph Bates was one of the first Adventists to speak out against tobacco and alcohol. During the pre-1863 period, Adventists began giving up tobacco, alcohol, tea, and coffee. Theological arguments used to justify these reforms included preparation for Christ's soon return, living to the glory of God, keeping the body a fit temple for the Holy Spirit, stewardship of God's money, and obedience to the prophetic visions of Ellen White. 
After Ellen White's major health vision of 1863 , Adventists began to see health reform as part of the Adventist message. They saw violation of health principles as violations of both the moral and natural law and as having negative effects on one's spirituality.

Adventists concluded from their belief in the wholistic nature of humans that people must be saved as a whole-body, soul, and spirit. They soon began using the teaching of healthful living as a means of reaching people with the whole gospel. Arguments for health reform used before 1863 continued to be used with the added motivation that the reforms were seen as part of the third angel's message. After E. G. White's vision in 1865, Adventists, both ministers and members, became actively involved in health evangelism. For them, medical missionary work became the gospel in practice.

In the brief description of the development of health evangelism in Europe, the progress in Switzerland, Great Britain, and Norway characterizes the work in most parts of Europe. Thanks to the personal visits, efforts, and writings of Ellen G. White, and the labors of Dr. John Harvey Kellogg, Dr. Kress, Dr. Nissen, and many others who attracted evangelistic audiences with a primary emphasis on healthful living, crowds were converted and new churches organized. Moreover, Ellen White's counsel regarding establishing health institutions has been followed as such.

The rationale of chapter 6 is to propose for Latvia a tentative program of health evangelism, which has not yet been fully implemented in that country. A 
three-phased strategy has been suggested, describing a health evangelism program, its implementation, and evaluation.

The church is called to be a training center, where a pastor is leading and teaching the church members the principles of ministry. Several health-oriented seminars would be especially helpful in this setting, including the Eight Essentials of Health, Hydrotherapy, Cooking School, Stress Management, Prayer Healing Ministry, and other health promotional activities. By being equipped for ministry, the laity can spread the gospel in a practical way through presentation of churchsponsored health programs and seminars in their local communities, and in new fields during evangelistic campaigns. Health food restaurants are projected as entry points to different classes of society.

The climax of the program could be the establishment of medical institutions such as a medical or dental clinic, a nursing home, and other selfsupporting health ministries, which are an advanced step in health evangelistic ministry in Latvia. Practical suggestions and guidelines are offered for the implementation and evaluation of the program.

\section{Conclusions}

The findings in this research lead to the following conclusions:

1. Contemporary Latvian society presents great and challenging opportunities for Seventh-day Adventist evangelism for two main reasons. First, the church is called to proclaim the gospel to everyone. Second, the population of the country is going through an unstable, tough, and demanding time when 
everything seems to be in a state of radical change. Old foundations have been destroyed and new ones are not yet fully established.

2. The Bible throughout all its pages emphasizes God's willingness to restore fallen human beings to the perfect image of God: spiritually, mentally, and physically.

3. Thanks to the efforts of the faithful pioneers in the Adventist movement and the personal presentations and writings of Ellen G. White, the worldwide Seventh-day Adventist church has considered health evangelism as the gospel in practice.

4. The Adventist church in Latvia has used various methods and approaches to proclaim the gospel. These were successful in the past and led people to Christ. Today, however, the old methods and structures do not bring the desired results. Thus, there is an urgent need for new approaches, with health evangelism being one of them.

5. The preparation of the church and the implementation of health-oriented seminars, health food restaurants, and medical institutions will help Latvian Adventists to reach people where they are and give them new opportunities of a happy life with Jesus Christ as their Healer and Restorer.

6. This health evangelistic program is designed as an effective tool, part of an ongoing ministry to accomplish what Christ commanded His people to do: "Go into all the world and proclaim the good news to the whole creation" (Mark 16:15). 


\section{Recommendations}

It is very difficult to give detailed and precise recommendations for health evangelism in Latvia. Specific decisions about the implementation of the proposed program should be made by the Latvian Conference and local pastors together with interested and equipped laity, based on their awareness of changing circumstances and their observations of God's leading.

However, several suggestions should be mentioned, which, if accepted, could lead to effective and successful evangelism, which would not only increase the church membership, but would also enrich people's lives and prepare them for the second coming of Christ.

1. By faith the church should step forward and start health evangelism programs. There may be mistakes at the outset of implementing this new program such as of being misunderstood or of failing financially. If this is the case, let the church consider them, make sound conclusions, and move forward. The tentative health program that is to be implemented should be always kept flexible.

2. The Latvian Conference should support health evangelism in all its varieties and diversities. Therefore, in order to carry out this new church activity, an insightful practical work should be done and its goals should be clearly presented before the church members.

3. Each local church should establish a local health evangelism program, in which the Health Ministries department will be in charge of health education, recommending lifestyle changes, and promoting health evangelism. 
4. The new program should be based on the belief and motivating force of involving as many church members as possible, thus providing them with opportunities of using their own spiritual gifts. In order to be equipped and ready for its mission in the country, the church needs the gifts, capabilities, and potential of every member.

5. All health advocates should remember that they are not only to provide medical care but, most importantly, to share the gospel in their communities.

6. Preventive care should take prevalence over curative healing processes.

7. The church should be sensitive to the specific needs of its particular community. The socio-cultural environment and its sway on the church's life and the impact of the church on community should be well investigated. The church needs to be familiar with the wide-ranging characteristics of those whom it is attempting to reach. It implies such questions as what is their social, educational, and financial status, etc.

8. The last and the main point mentioned should be that being under the guidance of the Holy Spirit, the Adventist church in Latvia can become educated, empowered, equipped, and inspired not only to start this new health evangelism program, but also to reap the harvest. 
APPENDIX: MAPS 


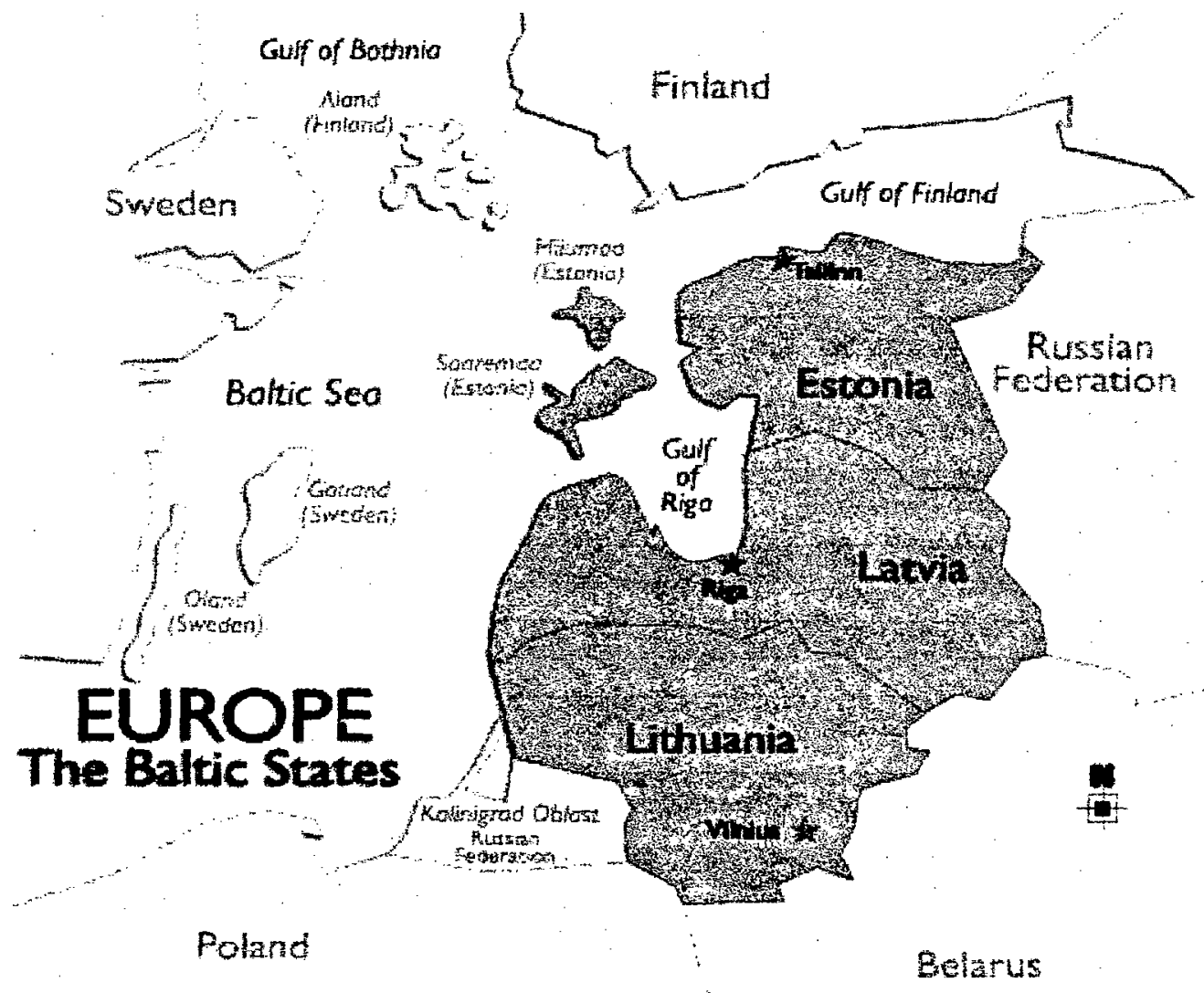

Map of the Baltic States. From "World Atlas Europe's Baltic States Map," $<$ http://www.worldatlas.com/webimage/countrys/europe/baltic.htm> (accessed 21 May 2002). 


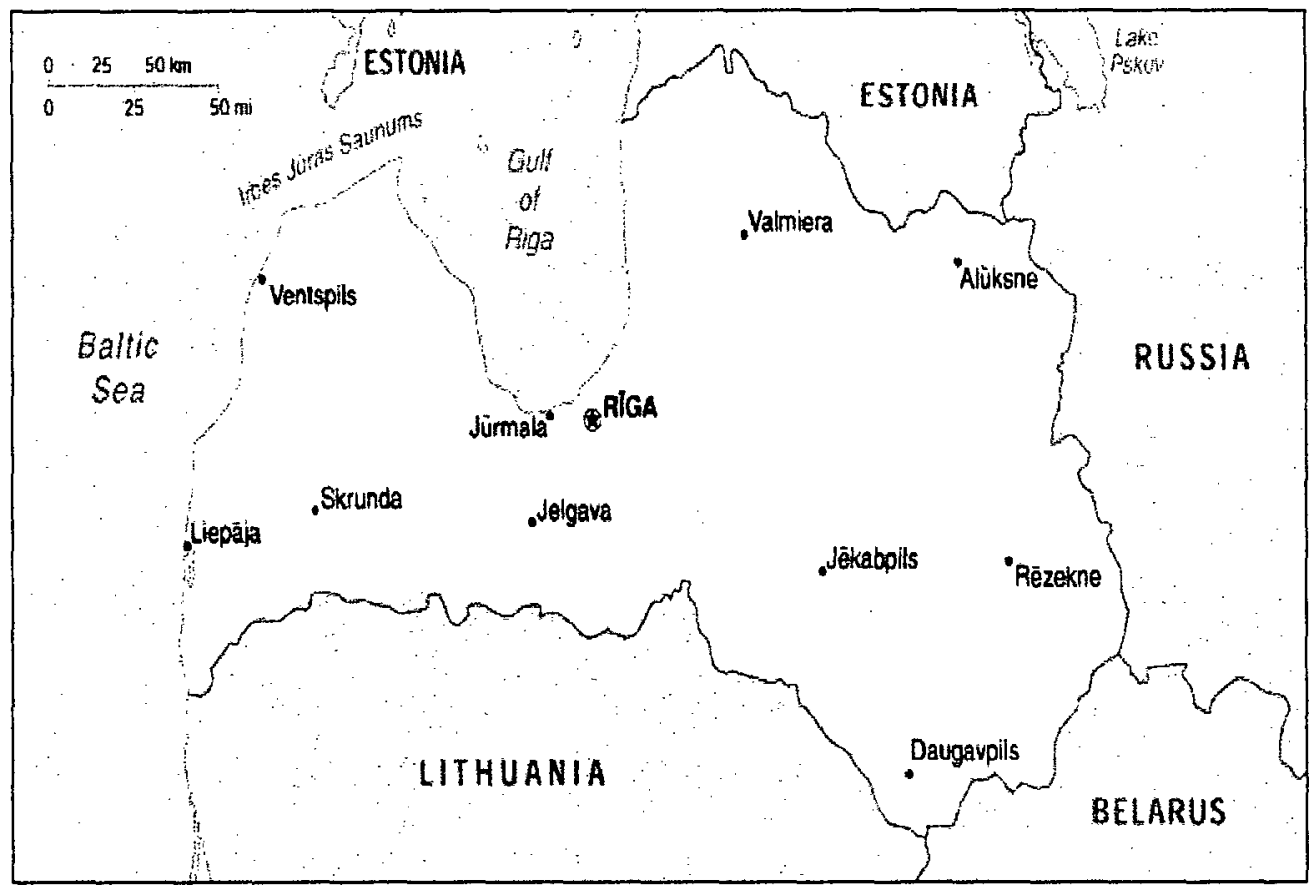

Map of Latvia. From "World Atlas CIA Map," $<$ http://www.worldatlas.com/webimage/countrys/europe/ciamaps/lv.htm $>$ (accessed 21 May 2002). 


\section{BIBLIOGRAPHY}

Abrahamsen, Karl. Norsk Bokforlag 100 år. Oslo: n.p., 1979.

Andross, Matilda Erickson. Story of the Advent Message. Washington, DC: Review and Herald, 1926.

Arbuckle, Gerald A. Healthcare Ministry. Collegeville, MN: Liturgical Press, 2000.

Autrey, C. E. Basic Evangelism. Grand Rapids, MI: Zondervan, 1954.

Baldwin, Marjorie V. "A Christian Worldview of Healing." Health and Healing 21 (1998): 16-17.

Balodis, Ringolds. Valsts un Baznīca. Riga, Latvia: Nordic, 2000.

Barna, George. Evangelism That Works. Ventura, CA: Regal, 1995.

. Turn-Around Churches. Ventura, CA: Regal Books, 1993.

Barnhart, Robert K. "Heroic." The World Book Dictionary. 2 vols. Chicago: World Books, 1995. 1:993.

Baumans, B. "Draudžu Dzīve: Baldone." Adventes Vēstnesis 4 (1926): 44.

Beall, Otho T., Jr., and Richard H. Shryock. Cotton Mather: First Significant Figure in American Medicine. Publications of the Institute of the History of Medicine, First Series. Baltimore, MD: Johns Hopkins University Press, 1954.

Beeson, Trevor. Discretion and Valour. Glasgow: Collins, 1982.

Belvedere, Daniel. "Motivating Lay Members for Mission." In Re-Visioning Adventist Mission in Europe, ed. Erich W. Baumgartner, 184-189. Berrien Springs, MI: Andrews University, 1998.

"Bezdarba Līmenis." Galvenie Sociālekonomiskie Rādītāji.

$<$ http:www.csb.lv/Satr/rad/D3.cfm?kurs3=D3> (31 March 2002). 
Bigelow, Jacob. Brief Exposition of Rational Medicine. Boston: Philips, Samson, and Company, 1858.

Bilmanis, Alfred. A History of Latvia. Westport, CT: Greenwood, 1951.

Bilocerkowycz, Jaroslav. "Latvia." A-to-Z Geography.

$<$ http://school.discovery.com/homeworkhelp/worldbook/atozgeography/1/3 14760.html> (25 October 2001).

Bite, A. "Savāda Sastapšanās." Adventes Vēstis, February 1999, 8.

Brown, Michael L. "'I Am the Lord Your Healer': A Philological Study of the Root 'Rapa' in the Hebrew Bible and the Ancient Near East." Ph.D. dissertation, New York University, 1985.

. Israel's Divine Healer. Grand Rapids, MI: Zondervan, 1995.

Brown, Raymond E., et al. "The Gospel Miracles." The Jerome Biblical Commentary, vol. 2. Englewood Cliffs, NY: Prentice-Hall, 1968.

Brunner, Emil. The Mediator. London: Lutterworth, 1962.

Cameron, Earl P. Evangelism in Today's World. Oshawa, Canada: Maracle, 1996.

“A Captive Audience." Record, 26 October 1996, 4.

Cardona, George. The World Book Encyclopedia. 1996 ed. S.v. "Language."

Cassuto, U. From Adam to Noah: A Commentary on the Book of Genesis. 2 vols. Jerusalem: Magnes, 1998.

Černevskis, E. Adventes Kustība Latvijā. Riga, Latvia: Patmos, 1998.

"The Contemporary Latvian Family." <http://www.latinst.lv/family.htm $>$ (7 September 2001).

Damsteegt, P. Gerard. Foundations of the Seventh-day Adventist Message and Mission. Berrien Springs, MI: Andrews University Press, 1995.

Daniels, A.G., and L. A. Hoopes. "Remarks by Mrs. E. G. White." General Conference Bulletin, 12 April 1901, 203, 204.

Delafield, D. A. Ellen White in Europe. Washington, DC: Review and Herald, 1975. 
Diehl, Hans, and Aileen Ludington. Lifestyle Capsules. Santa Barbara, CA: Woodbridge, 1991.

Dorris, Tom. "Northern Europe." In Remembering the Future: The Challenge of the Churches in Europe, ed. Robert C. Lodwick. New York: Friendship, 1995.

Dybdahl, Jon. "Faith and Healing." In Health 2000 and Beyond, ed. Stoy Proctor, 203-210. Silver Spring, MD: General Conference of Seventh-day Adventists, 1994.

Dysinger, William. Heaven's Lifestyle Today. Silver Spring, MD: General Conference of Seventh-day Adventists, Ministerial Association, 1997.

Easum, William. The Complete Ministry Audit: How to Measure 20 Principles for Growth. Nashville: Abingdon, 1996.

Ellen G. White and Europe 1885/1887: Symposium Papers. Bracknell, Berks., England: Ellen G. White Research Center, 1987.

Eriks, Kenneth. Reach Out \& Receive. New York: Reformed Church, 1988.

"Facts About Latvian History." <http://www.cc.jyu.fi/ wlad/latvia/latvia.html $>$ (11 September 2001).

Ferriar, John. Medical Histories and Reflections. Philadelphia, PA: Thomas Dobson, 1816.

Flaiz, T. R. "Our Bodies a Living Sacrifice." In Our Firm Foundation, 2:359. Washington, DC: Review and Herald, 1953.

Flynn, Mike, and Doug Gregg. Inner Healing. Downers Grove, IL: InterVersity, 1993.

Ford, Paul R. Discovering Your Ministry Identity. USA: ChurchSmart, 1998.

Fretheim, Terence E. "The Book of Genesis." The New Interpreter's Bible. Nashville: Abingdon, 1994. 1:319-674.

General Conference of Seventh-day Adventists. $135^{\text {th }}$ Annual Statistical Report. Silver Spring, MD: General Conference of SDA, 1997.

"General Schools." <http://www.csb.lv/Satr/rad/M1a.cfm?akurs03=M1a $>$ (18 September 2001). 
Global Partners. Loma Linda, CA: Loma Linda University and Medical Center, 1996. Videocassette.

Gordon, Jack. "Training Terms: What Does Wholistic Mean?" Training Magazine, September 1987, 66. Quoted in Russel Chandler, Understanding the New Age. Dallas, TX: Word, 1988.

Graber, F., and D. Muller. "Heal." The New International Dictionary of New Testament Theology. Edited by Collin Brown. Grand Rapids: Zondervan, 1986. 2:168-171.

Graham, Sylvester. Lectures on the Science of Human Life. 2 vols. Boston: Marsh, Capen, Lyon, and Webb, 1839.

Griffenhagen, George. The Story of California Pharmacy. Madison, WI: American Institute of the History of Pharmacy, 1950.

Gulley, Norman R. "Gospel-Medical Evangelism.” Syllabus for Medical Evangelism Cource, Madison College, n.d.

Hagstotz, Gideon David. The Seventh-day Adventists in the British Isles. Lincoln, NE: Union College Press, 1936.

Hamilton, Victor P. The Book of Genesis, Chapters 1-17. The New International Commentary on the Old Testament. Grand Rapids: Eerdmans, 1990.

Hamm, Dennis M. "This Sign of Healing, Acts 3: 1-10: A Study in Lucan Theology." Ph.D. dissertation, Saint Louis University, 1975.

The HarperCollins Dictionary of Religion. Edited by Jonathan Z. Smith. New York: HarperCollins, 1995. S.v. "Adventists," "Old Believers."

"Health Education." <http://www.who.dk/NEHAP/Lat/Lchap58.html> (10 September 2001).

Hechtlinger, Adelaide. The Great Patent Medicine Era, or, Without Benefit of Doctor. New York: Galahad Books, 1970

Hiltner, Seward. Preface to Pastoral Theology. Nashville: Abingdon, 1958.

"History, Language, Identity and Culture of Latvia." $<$ http://www.lettland.nu/info/latvia.identity.html $>$ (11 September 2001).

"History." <http://www.randburg.com/lv/history> (11 September 2001). 
"HIV/AIDS Cases by Year of Diagnosis, September 15, 2001." < $<$ ttp://www.aidsLatvija.lv/Statistika/ikgad_1.html> (23 September 2001).

Hooker, Worthington. Rational Therapeutics. Boston: John Wilson and Sons, 1857.

Hubbard, Reuben A., and Don Hawley. Health Secrets of the Bible. Abundant Living Health Series. Loma Linda, CA: Loma Linda University, 1984.

Hutten, Kurt. Iron Curtain Christians. Minneapolis: Augsburg, 1967.

Iwaskiw, Walter R., ed. Estonia, Latvia, and Lithuania: Country Studies. Lanham, MD: Research Division, Library of Congress, 1996.

Jordan, Anne Devereaux. The Seventh-Day Adventists: A History. New York: Hippocrene Books, 1988.

Juris, A. "Draudžu Dzīve: Ādaži." Adventes Vētnesis 6 (1926): 63.

Jurkevics, A. "No Misijas Skolas." Adventes Vêstnesis 2 (1927): 12, 13.

Kaulina, Rita. "Cenšas Palīdzēt Bāreņiem un Bijušajem Ieslodzītajiem.” Adventes Vēstis, May 2001, 2.

Knight, George R. Ellen White's World: A Fascinating Look at the Times in Which She Lived. Hagerstown, MD: Review and Herald, 1998.

Knight, J. A. "The Minister as Healer, the Healer as Minister," Journal of Religion and Health 21 (1982): 100.

Kulakov, Mikhail. God's Soviet Miracles. Boise, ID: Pacific Press, 1993.

Kurlovics, Gunars, and Andris Tomasuns. Latvijas Vēsture. Riga, Latvia: Zvaigzne ABC, 2000.

"Labdaribas Centra 'Jauna Dzive' Atskaite." Adventes Vestis, February 1999, 7.

"Labor Legislation." <http://www.lda.gov.lv/index.php?b=18> (21 September 2001).

Larkin, Oliver Leon. "A Quest for Understanding the Issues in a Healing Ministry at a Local Church." D.Min. dissertation, Drew University, 1986.

LaRondelle, H. K. "The Remnant and the Three Angels' Messages." Handbook of Adventist Theology Commentary Reference Series. Hagerstown, MD: Review and Herald, 2000. 12:857-892. 
"Latvia." Record (South Pacific Division), 16 May 1998, 10.

"Latvia." <http://memory.loc.gov/cgibin/query/r?frd/cstdy:@field(DOCID+lv0008) $>$ (6 September 2001).

"Latvia Human Development Report," Chapter 3. $<$ http://www.un.lv/down/1995 e/chapter3.html > (3 October 2001).

"Latvia: Urbanization, Employment, and Education." $<$ http://lcweb2.loc.gov/cgibin/query/r?frd/cstdy:@field(DOCID+lv0019)> (10 September 2001).

"Latvian Christian Mission." <http://www.gospels.com/lcm.html> (3 October 2001).

Lawrence, Errol A. "The Medical Missionary Work of the SDA Church and Its Effect on the West African Union Mission." Term paper, Andrews University, 1991, Adventist Heritage Center, James White Library, Berrien Springs, MI.

"Leading Edge Technology Powers Latvian Studio." The Atlantic Union Gleaner, March 1996, 4.

Lehmann, R. P. "The Second Coming of Jesus." Handbook of Adventist Theology Commentary Reference Series. Hagerstown, MD: Review and Herald, 2000. 12:893-926.

Lohne, Alf. Adventists in Russia. Hagerstown, MD: Review and Herald, 1987.

Loyd, Wyndham E. B. A Hundred Years of Medicine. $2^{\text {nd }}$ ed. London: Gerald Duckworth \& Co., 1968.

MacCarty, Skip. Stress: Beyond Coping. Berrien Springs, MI: The Author, 1997.

Maddocks, Morris. The Christian Healing Ministry. London: SPCK, 1981.

Mann, Horace. "The Study of Physiology in the Schools." In Annual Reports on Education, ed. Mary Tyler Mann. Vol. 3 of Life and Works of Horace Mann. Boston: Horace B. Fuller, 1868.

Mathews, Kenneth A. Genesis 1-11:26. The New American Commentary. Nashville: Broadman \& Holman, 1996.

Maxwell, C. Mervyn. Tell It to the World. Mountain View, CA: Pacific Press, 1977. 
Mazura, Antra. "Education for All."

<http://www2.unesco.org/wef/countryreports/latvia/repport 22 2.html > (20 September 2001).

Miller, William R., and Kathleen A. Jackson. Practical Psychology for Pastors. Englewood Cliffs, NJ: Prentice Hall, 1985.

Mojzes, Paul. Church and State in Postwar Eastern Europe. Westport, CT: Greenwood, 1987.

Moon, Jerry. "The Rise of the Self-Supporting Movement in Seventh-day Adventist Education." Research paper, Andrews University, May 1988.

"More Than Half of the Population of Latvia Has Secondary Education." $<$ http://www.csb.lv/ateksts.cfm?tem_kods=tsk\&datums $>$ (18 September 2001), press release.

Moskala, Jiri. The Laws of Clean and Unclean Animals of Leviticus 11: Their Nature, Theology, and Rationale. Berrien Springs, MI: ATSP, 1998.

Nedley, Neil. Proof Positive: How to Reliably Combat Disease and Achieve Optimal Health through Nutrition and Lifestyle. Ardmore, OK: By the author, 1999.

"Newbold Goes Off-Campus." Record, 18 April 1998, 5.

"Number of HIV Cases by Age Group and Sex, September 15, 2001." $<$ http://www.aids-latvija.lv/Statistica/vecumi 1.html> (23 September 2001).

Olsen, Ellsworth. A History of the Origin and Progress of Seventh-day Adventists. Washington, DC: Review and Herald, 1925.

Olsen, V. N. "Wholistic Health--the Adventist Slant." Adventist Review, 19 January 1984, 7-8.

Oltin̄š, J. "Latvijas Adventes Misijas Seminārs." Adventes Vēstnesis 7 (1938): 156.

Owen, A. B. "Belfast Sanitarium." The Medical Missionary and Gospel of Health, January 1903, 26.

Paulien, Gunther B. The Divine Prescription and Science of Health and Healing. Brushton, NY: TEACH Services, 1997.

Peckham, Kim. "Together Forever." Adventist Review, January 31, 2002, 14-15. 
Pelēkais, G., A. Bērzin̄š, G. Kiršteins, and A. Saulgriezis. Latvija. Riga, Latvia: SIA ,LKC“, 1997.

"Pērn Latvijā Abortu Skaits Par Gandrīz 2000 Pārsniedzis Jaunpiedzimušo Skaitu." <http://www.leta2000.com> (9 September 2001).

"Population." Basic Socio-Economic Indicators. $<$ http://www.csb.lv/Satr/rad/Cl.cfm?akurs3=C1 $>$ (31 August 2001).

Priedītis, Artūrs. Latvijas Kultūras Vèsture. Daugavpils, Latvia: A.K.A., 2000.

"Public Health in Latvia with Particular Reference to Health Promotion." $\leq$ http://www.rhpeo.org/ijhp-articles/1998/6/> (6 September, 2001).

Reid, George Wayne. "Health and Healing." In Handbook of Seventh-day Adventist Theology Commentary Reference Series, ed. George W. Reid. Hagerstown, MD: Review and Herald, 2000.

. "The Foundations and Early Development of the Health Emphasis Among Seventh-day Adventists." Th.D. dissertation, Southwestern Baptist Theological Seminary, 1976. . A Sound of Trumpets. Washington, DC: Review and Herald, 1982.

"Riga Meetings Draw Record Crowds." Messenger, 31 March 1995, 2.

Robinson, Dores Eugene. The Story of Our Health Message. Nashville, TN: Southern Publishing Association, 1943.

Rothstein, William G. American Physicians in the Nineteenth Century: From Sects to Science. Baltimore, MD: Johns Hopkins University Press, 1972.

Roze, Kārlis. "Pirmā Pusgada Darbs un Panākumi Liepājā." Adventes Vēstnesis 5 (1924): 54, 55.

Sailhamer, John H. The Pentateuch as Narrative. Grand Rapids: Zondervan, 1992.

Samaan, Philip G. Christ's Way to Spiritual Growth. Hagerstown, MD: Review and Herald, 1995.

Schaefer, Richard A. Legacy. Mountain View, CA: Pacific Press, 1977.

Schwarz, Richard William. "John Harvey Kellogg: American Health Reformer." Ph.D. dissertation, University of Michigan, 1964. 
Seventh-day Adventist Encyclopedia. 1966 ed. S.v. "Great Britain and Northern Ireland," "Norway."

Shryock, Richard H. Medicine in America, Historical Essays. Baltimore, MD: Johns Hopkins University Press, 1966.

Singer, Charles, and Ashworth Underwood. A Short History of Medicine. $2^{\text {nd }}$ ed. New York and Oxford: Oxford University Press, 1962.

Smith, Glenn. "Mann, Horace." World Book Encyclopedia. 1996. 13:164.

Steeves, Paul D. Keeping the Faiths. New York: Holmes \& Meier, 1989.

Steinbron, Melvin J. Can the Pastor Do It Alone? Ventura, CA: Regal Books, 1987.

Stenbakken, Rikki. "Deaf Services Reach Out to World Church." Outlook (MidAmerica Union), June 1994, 29.

Thomas, Charles, G. Damsteegt, and L. Enachescu. Source Book for the Workshop in Hydrotherapy and Home Remedies. Berrien Springs, MI: Andrews University Theological Seminary, 1998.

Thompson, Walter C. Managing Stress by the Power of God's Love. Siloam Springs, AR: Creation Enterprises International, 1991.

"Tobacco or Health: A Global Status Report, Latvia." $<$ http://www.cdc.gov/tobacco/who/Latvia.html $>$ (6 September 2001).

Tomsone, T. "Komunikācijas Nodaja." Adventes Vēstis, October 2000, 7.

Tomsons, Aidis. "Par Draudzes İpašumiem." Adventes Vēstis, November 2000, 2. . "Rādio Darbs." Adventes Vèstis, March 2001, 2, 3.

Towns, Elmer, and Warren Bird. Into the Future. Grand Rapids, MI: Fleming H. Revell, 2000.

"The Unemployment Rate Remains Stable." $<$ http://www.csb.lv/ateksts.cfm?tem_kods=bezd\%5Fv\&datums $>$ (18 September 2001).

Unger, Merrill F. The New Ungers Bible Dictionary, 1988. S.v. "Self-control." 
"U.S. Department of State Annual Report on International Religious Freedom for 1999: Latvia." <http://www.state.gov/www/global/human rights/irf/irf_rpt/1999/irf latvia99.html $>$ (16 October 2001).

Usackis, Uldis. "Latvijas Iedzīvotāju Skaits Turpina Samazināties." $<$ http://www.csb.lv/lteksts.cfm?tem kods=dem\&datums $>$ (7 September 2001).

. "Turpina Samazināties Noslēgto Laulību Skaits." <http://www.csb.lv> (17 September 2001).

Van Dolson, Leo R., and J. Robert Spangler. Healthy, Happy, Holy. Washington, DC: Review and Herald, 1975.

Vaskis, Edmunds. "Living Conditions in Latvia." $<$ http://www.csb.lv/Pres/livcond1.htm $>$ (18 September 2001).

Vinglass, R. “Atminas par Semināru Latvijā." Adventes Vēstnesis 7 (1938): 163.

Vyhmeister, N. J. "Who Are Seventh-day Adventists?" Handbook of Adventist Theology Commentary Reference Series. Hagerstown, MD: Review and Herald, 2000. 12:1-21.

Vyhmeister, Werner. "What Can Laypersons Do in Ministry." In Adventist Mission in the $21^{s t}$ Century, ed. Jon L. Dybdahl. Hagerstown, MD: Review and Herald, 1999.

Waggoner, J. H. "Moral Duty of Preserving Health." Health Reformer, February 1872, 51. Quoted in P. Gerard Damsteegt, Foundations of the Seventh-day Adventist Message and Mission. Berrien Springs, MI: Andrews University Press.

"Present Truth," Review and Herald, 7 August 1866.

Wagner, Peter C. Prayer Shield. Ventura, CA: Regal, 1992.

Wenham, Gordon J. Genesis 1-15. Word Biblical Commentary, vol. 1. Waco, TX: Word, 1987.

White, James. "The Health Reformer." $H R$, December 1873, 372. Quoted in P. Gerard Damsteegt, Foundations of the Seventh-day Adventist Message and Mission. Berrien Springs, MI: Andrews University Press, 1995.

White, Ellen G. Christ's Object Lessons. Washington, DC: Review and Herald, 1941. 
. "The Conference at Basel." Review and Herald, 19 April 1887, 241.

. Counsels on Health and Instruction to Medical Workers. Mountain

View, CA: Pacific Press, 1923.

. Counsels on Diet and Foods. Washington, DC: Review and Herald, 1976.

. Counsels to Parents, Teachers, and Students. Mountain View, CA:

Pacific Press, 1943.

. The Desire of Ages. Boise, ID: Pacific Press, 1940.

. "Disease and Its Causes--Impure Air." Review and Herald, 5 December 1899.

. Early Writings. Washington, DC: Review and Herald, 1945.

. Education. Mountain View, CA: Pacific Press, 1952.

. Evangelism. Washington, DC: Review and Herald, 1946.

. General Conference Bulletin, 3 April 1901. Quoted in Dores Eugene Robinson, The Story of Our Health Message. Nashville, TN: Southern Publishing Association, 1943.

. Healthful Living. Battle Creek, MI: Medical Missionary Board, 1898.

. "The Health Reformer." HR, December 1873, 372. Quoted in P. Gerard Damsteegt, Foundations of the Seventh-day Adventist Message and Mission. Berrien Springs, MI: Andrews University Press.

. Historical Sketches of the Foreign Missions of the Seventh-day Adventists. Basle: Imprimerie Polyglotte, 1886.

. Manuscript 29, 1887. Quoted in D. A. Delafield, Ellen White in Europe. Washington, DC: Review and Herald, 1975.

. Letter 4, 1863. Quoted in Dores Eugene Robinson, The Story of Our Health Message. Nashville, TN: Southern Publishing Association, 1943.

. Medical Ministry. Boise, ID: Pacific Press, 1963.

. The Ministry of Healing. Boise, ID: Pacific Press, 1988.

. My Life Today. Washington, DC: Review and Herald, 1952. 
. "Parents Their Own Physicians." Health Reformer, October 1866, 36. Quoted in P.Gerard Damsteegt, Foundations of the Seventh-day Adventist Message and Mission. Berrien Springs, MI: Andrews University Press.

. Patriarchs and Prophets. Boise, ID: Pacific Press, 1958.

. Prophets and Kings. Mountain View, CA: Pacific Press, 1943.

. Reflecting Christ. Hagerstown, MD: Review and Herald, 1985.

. Selected Messages. 3 vols. Hagerstown, MD: Review and Herald, 1980, 1:34.

. Sons and Daughters of God. Washington, DC: Review and Herald, 1955.

. Spiritual Gifts. 4 vols. Washington, DC: Review and Herald, 1945.

. Steps to Christ. Boise, ID: Pacific Press, 1981.

. Testimonies for the Church. 9 vols. Boise, ID: Pacific Press, 1995.

. Welfare Ministry. Washington, DC: Review and Herald, 1952.

Wilkinson, John. Health and Healing. Edinburgh: Handsel, 1980.

. The Bible and Healing. Edinburgh: Handsel, 1998.

Williams, D. S., K. Kuzma, and L. R. Van Dolson. Ministries of Health and Healing. Silver Spring, MD: North American Division of the SDA Church, 1997.

Wilson, Measapogu. "A Health Evangelism Strategy for Reaching Rural Indians with Giffard Memorial Hospital as a Model." D.Min. dissertation, Andrews University, 1999.

"World Atlas CIA Map." $<$ http://www.worldatlas.com/webimage/countrys/europe/ciamaps/lv.htm $>$ (21 May 2002).

"World Atlas Europe's Baltic States Map." $<$ http://www.worldatlas.com/webimage/countrys/europe/baltic.htm $>$ (21 May 2002).

The World Book Encyclopedia. Chicago, IL: World Book, 1996. S.v. "Language," "Latvia." 
World Health Organization. "Latvia." $<$ http://www. who.dk/NEHAP/Lat/Lchap58.htm> (10 September 2001). . "Highlights on Health in Latvia." $<$ http://www.who.dk/document/e72407.pdf> (8 October 2001).

"Yearly Growth Analysis: Latvian Conference (1936-1998)." $\leq$ http:/statistics.gc.Adventist.org/ast/stats $>$ (20 January 2002). 